\title{
AZ ÁRPÁD-KORI EGRI PÜSPÖKI KÖZPONT KIALAKULÁSA
}

\author{
BUZÁs GERGELY*
}

\begin{abstract}
2016-2019 között végeztünk feltárásokat az egri várban. Ezek során a vár, illetve az egri püspöki központ 11-13. századi történetére vonatkozó fontos új megfigyeléseket tehettünk. A régészeti megfigyelések alapján a vár legkorábbi elözményeként egy 11. század első feléből származó királyi udvarház épületeit azonosítottuk. Véleményünk szerint ez fogadta be az 1068 után elöször ideiglenesen, majd 1091 után véglegesen az egyházmegye központját, amely korábban Bihar várában lehetett. Rekonstruáltuk a román kori székesegyház épitéstörténetét, és nagyrészt feltártuk a székesegyház északi oldalán a 12. század folyamán több lépésben kiépült káptalani kerengőt és püspöki palotát, valamint több ponton azonositottuk a 13. század első felében kiépülö, két részból álló első püspökvár falait (1. kép).
\end{abstract}

Kulcsszavak: Eger, középkor, épitészettörténet, román kori épitészet, katedrális, káptalani kerengö, vár

Between 2016 and 2019, we conducted a series of excavations in Eger Castle, in the course of which we gained a number of new insights regarding the 11th-13th century history of the castle and the episcopal seat. On the testimony of the written sources and the archaeological record, the castle's earliest antecedent was a royal manor house from the first half of the 11th century. In our view, this building functioned as the centre of the diocese - which had earlier probably been located in Bihar Castle - first temporarily after 1068, then, after 1091, permanently. We were able to reconstruct the architectural history of the Romanesque cathedral and we excavated the cathedral's cloister and the episcopal palace on the cathedral's northern side, built in a number of successive phases. We also succeeded in identifying the walls of the first episcopal castle built in the first half of the 13th century (Fig. 1).

Keywords: Eger, Middle Ages, architectural history, Romanesque architecture, cathedral, cathedral cloister, castle

Kézirat beérkezett: 2020. március 3. Kézirat elfogadva: 2020. június 29.

* Buzás Gergely: Magyar Nemzeti Múzeum Mátyás Király Múzeuma; 2025 Visegrád, Fő u. 23.; e-mail: buzasgergely@visegradmuzeum.hu 
Az egri vár tervezett helyreállításának elókészítéseként 2016-ban két próbaásatást, ${ }^{1}$ 2017-ben, ${ }^{2}$ majd 2019-ben ${ }^{3}$ két megelőző feltárást folytat-

1 A Modern Városok Program keretében, a vár északi felében tervezett helyreállításokhoz kapcsolódó próbaásatást a Forster Központ (ma Várkapitányság Integrált Területfejlesztési Központ Nonprofit Zrt.) megbízásából, a Salisbury Kft.-vel a Magyar Nemzeti Múzeum Mátyás Király Múzeumával (MNM MKM) és a Pázmány Péter Katolikus Egyetem (PPKE) Régészettudományi Intézetével együttmúködésben végeztük el két szakaszban. A munka első szakaszában, 2016. 06. 07. és 2016. 06. 17. között a várszékesegyház hosszházában és a hosszház északi előterében nyitottunk 5 szelvényt, a munka 2016. 07. 05. - 2016. 07. 08. közötti második szakaszában az északi várkapu belső oldalán nyitottunk két szelvényt. Ásatásvezető: Buzás Gergely (MNM MKM), technikusok: Dávid Áron (Salisbury Kft.), Blaskó Martin (Salisbury Kft.), Lóki Róbert (PPKE), Lóki Eszter (PPKE). Az ásatás előzetes jelentése: BUZÁs 2017a.

A vár déli részének GINOP program keretében tervezett helyreállításának próbafeltárását 2016. 10. 18-27. közöt végeztük el a Forster Központ, a Salisbury Kft. és az MNM Mátyás Király Múzeumának együttmúködésével. A próbafeltárás során három területet vizsgáltunk: a délkeleti fülesbástya déli felének belső részét, a Varkoch-kapu előterét és a délnyugati ágyúdombot. Ásatásvezető: Buzás Gergely (MNM MKM), ásatási technikusok: Princz Diána (MNM MKM), Szabó Orsolya (Salisbury Kft.), Rácz Barbara (Salisbury Kft.).

2 A Modern Városok Program keretében, a Dobó István Vármúzeum (DIV) és a Magyar Nemzeti Múzeum Mátyás Király Múzeumának együttmúködésével végzett megelőzó feltárás két szakaszban, 2017. 03. 29. és 2017. 06. 09., illetve 2017. 10. 10. és 2017. 11. 15. között öt helyszínre terjedt ki: a középkori székesegyház nyugati és északi oldalára, a gótikus püspöki palota keleti oldalára és a Zárkándy-bástyára. A területen 23 szelvényt nyitottunk, amelyekkel $1700 \mathrm{~m}^{2}$-es területet tártunk fel, 23503 darab leletet hoztunk felszínre. Ásatásvezető: Buzás Gergely (MNM MKM), régész munkatársak: Berecz Barbara (DIV), Boruzs Katalin (MNM MKM), Gróf Péter (MNM MKM), Kocsis Edit (MNM MKM), Kováts István (MNM MKM), régésztechnikusok: Princz Diána (MNM MKM), Rákóczi Gergely (DIV), Rosta Péter, Rácz Kristóf (DIV), Tanyi Sándor (DIV). A megelőző feltárással egy időben, a régészeti kutatással együttmúködve végezte el Bozóki Lajos múvészettörténész az északi várfal keleti szakaszának kutatását is. A felmérési dokumentáció készítésében Sandó Norbert (Pazirik Informatikai Kft.) múködött közre, a gépi földmunkát Kökény Krisztián (Visz-Fuvar Kft.), a kézi földmunkát az Ásatárs Kft. végezte el. Az ásatás előzetes jelentése: BuZÁs 2019a.

3 A GINOP program keretében 2019. július 15. és augusztus 14 között, a Magyar Nemzeti Múzeum Mátyás Király múzeuma és a Dobó István Vármúzeum együttmúködésével végeztük el az egri vár zászlódombjának teljes felületű megelőző feltárását. Összesen $886 \mathrm{~m}^{2}$-nyi területet vizsgáltunk meg, 424 egységben 8057 darab régészeti lelet került elő. Ásatásvezető: Buzás Gergely (MNM MKM), régész munkatársak: Berecz Barbara (DIV), Gróf Péter (MNM MKM), Kocsis Edit (MNM MKM), Mikesi Anna (MNM MKM), Princz Diána, régésztechnikusok: Molnár Éva (MNM MKM), Raáb Donát (DIV), Rácz Kristóf László (DIV), Rákóczi Gergely (DIV), Rosta Péter. A felmérési dokumentáció készítésében Sandó Norbert (Pazirik Informatikai Kft.) múködött közre, a gépi földmunkát Kökény Krisztián (Visz-Fuvar Kft.), a kézi föld- tunk (2-5. képek). A munkák elókészítése során a Dobó István Vármúzeum munkatársai szisztematikusan összegyújtötték, ${ }^{4}$ majd feldolgoztuk az egri vár korábbi feltárásainak dokumentációs anyagait ${ }^{5}$ és kőfaragvány leleteit. ${ }^{6} \mathrm{Az}$ új ásatások során alkalmunk nyílott olyan területek feltárására is, amelyhez a 19-20. századi beépítések miatt a korábbi kutatások nem férhettek hozzá. Ennek köszönhetően az egri vár történetének számos, korábban tisztázatlan kérdéséhez sikerült új adatokat szereznünk, és így most lehetôségünk nyílik a középkori vár és püspöki központ korai történetének felvázolására.

\section{Kutatástörténet}

Az egri vár régészeti kutatását 1862-ben Ipolyi Arnold kezdte meg, de az ő ásatása még csak a székesegyház késő gótikus szentélyét érintette. ${ }^{7}$ A folyamatos régészeti kutatások 1925-ben Pálosi Ervin és Pataki Vidor vezetésével indultak meg és 1940-ig tartottak. Ekkor tárták fel a székesegyház teljes területét, valamint a vár eródítményrendszerét is kutatták. ${ }^{8}$ A székesegyháztól északra eső területen 1935-ben egy istálló építése során egy kétszintes épület maradványait tárták fel, majd a kiásott falak egy részét visszabontották. Ettől az épülettól délre 1937-1938-ban kiásták a Szent István-templom falmaradványait. Amikor az 1870 óta a várban állomásozó katonaság 1957ben kivonult az épületegyüttesből, Kozák Károly - az Országos Múemléki Felügyelőség régésze kezdhetett a korábbiaknál sokkal nagyobb léptékú régészeti feltárásokba. A gótikus püspöki palota régészeti kutatását 1957-ben kezdte meg, és 1989-ben bekövetkezett haláláig vezette az egri vár ásatásait. ${ }^{9}$ Ebben az időszakban a vár csaknem teljes területén végzett új, vagy a régi kutatásokat hitelesító feltárásokat. Az 1990-es években az ásatások nagyrészt leálltak, és a

munkát az Ásatárs Kft. végezte el. Az ásatás előzetes jelentése: BuZÁs 2019b.

4 A korábbi ásatási dokumentációk rendezését és digitalizálását a Dobó István Vármúzeum munkatársai: Nagy László, Vágvölgyi Bence, Halász Ágoston és Havasy Orsolya végezték el.

5 2017-ben készítettem el Az egri vár épitéstörténete címú dokumentációt.

6 Az egri vár kőfaragványainak múvészettörténeti feldolgozásával 2000 óta foglalkozom (BUZÁs 2006).

7 IPOLYI 1865.

8 LÉNÁRT 1982.

9 DÉTSHY-KOZÁK 1964; KOZÁK 1966; DÉTSHY-KOZÁK 1967; KoZÁK 1969a; KoZÁK 1969b; KoZÁK 1972; KoZÁK-SEDLMAYR 1972; DÉTSHY-KOZÁK 1972; KOZÁK 1974; KOZÁK 1975; KOZÁK 1979; KOZÁK 1981; KOZÁK 1983; KOZÁK 1984b; KoZÁK 1986; KozÁK 1987; KoZÁK 1990. Kozák Károly ásatásaiban Kárpáti János is közremúködött: KÁRPÁTI 2010. 


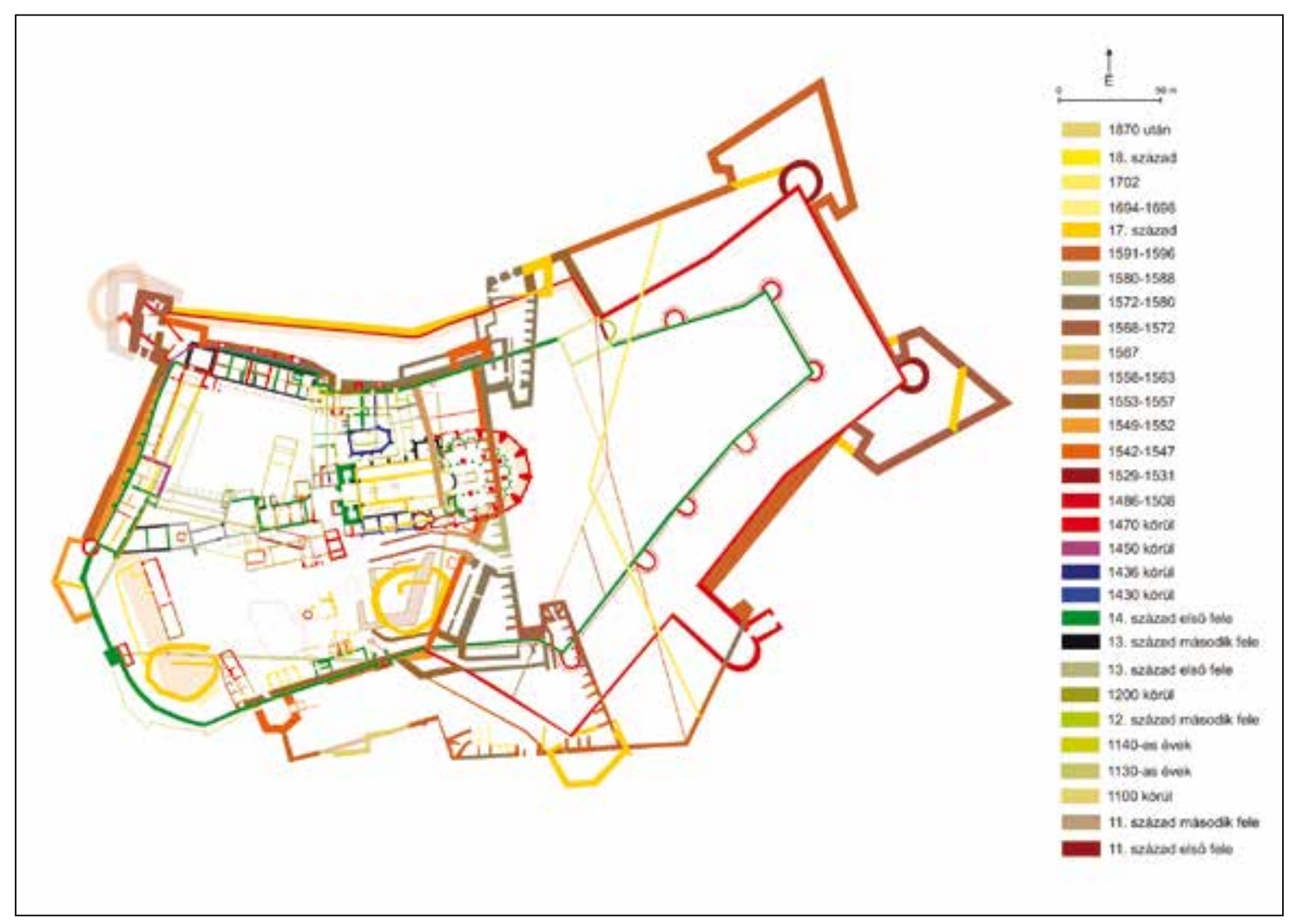

1. kép. Az egri vár periodizált alaprajza

Fig. 1. Plan of Eger Castle with the architectural periods

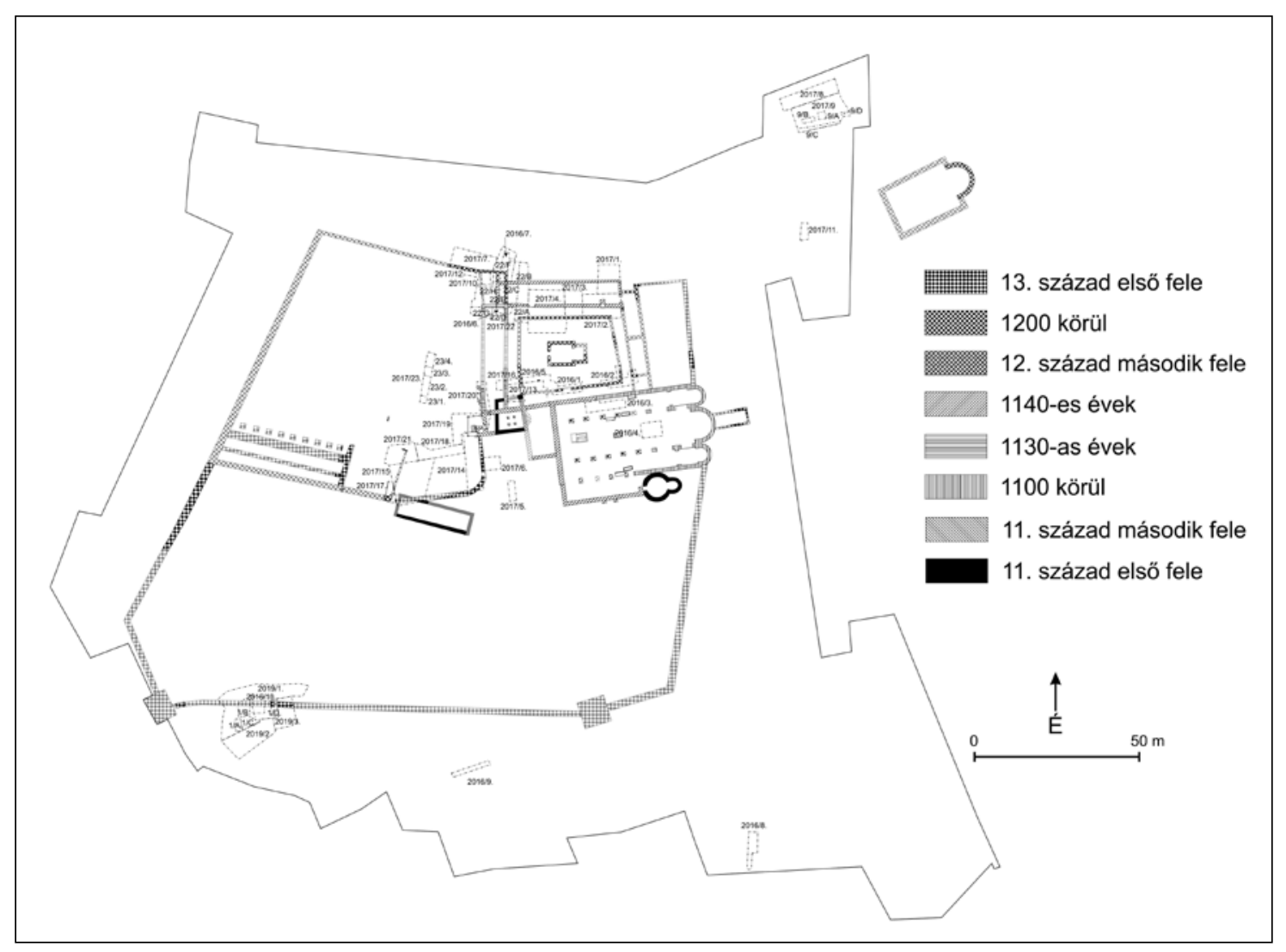

2. kép. Ásatási helyszínrajz a tatárjárás előtti épületek feltüntetésével

Fig. 2. Excavation plan showing the buildings predating the Mongolian invasion 


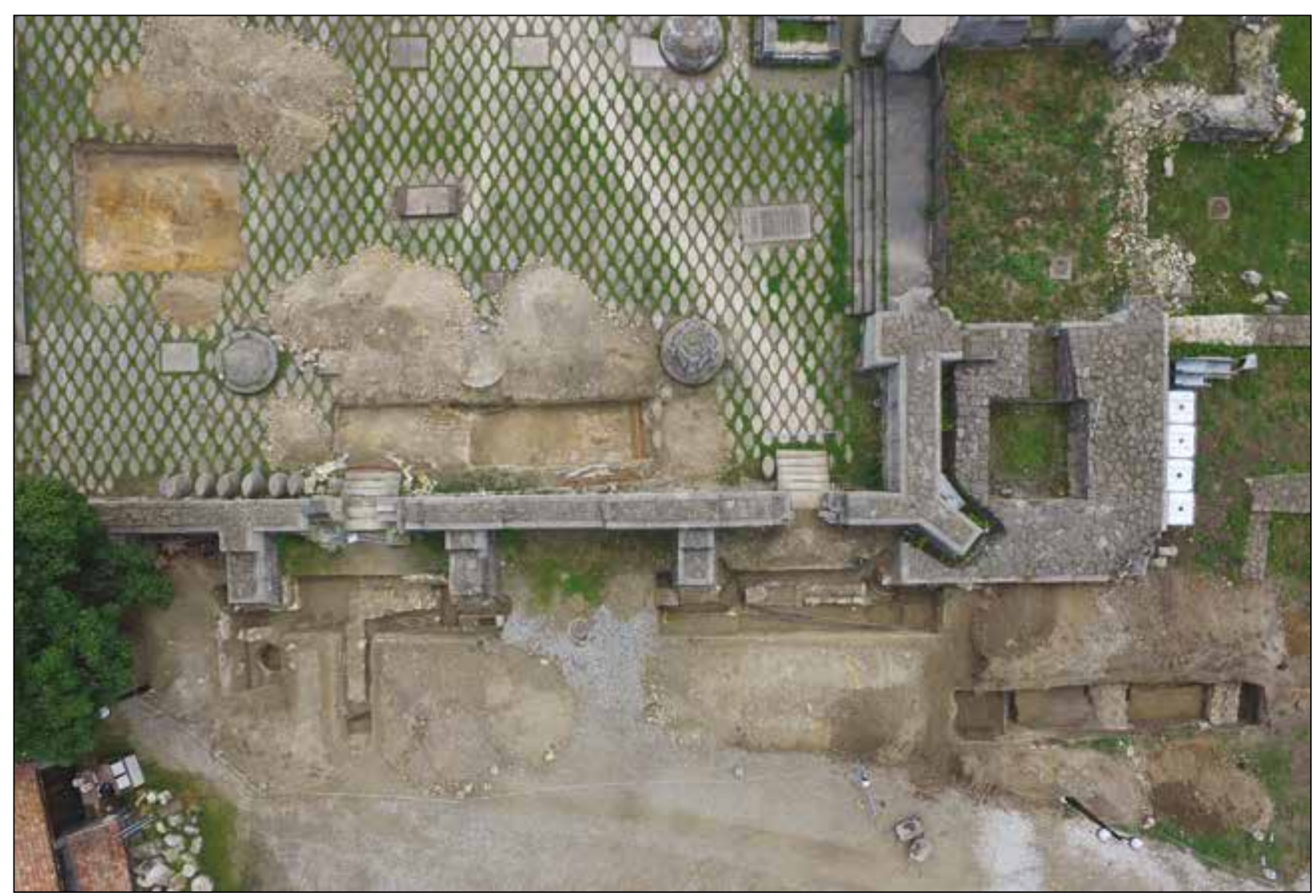

3. kép. A székesegyház északi felének 2016. évi ásatási légifotója

Fig. 3. Aerial photo of the excavated area in the cathedral's northern half, 2016

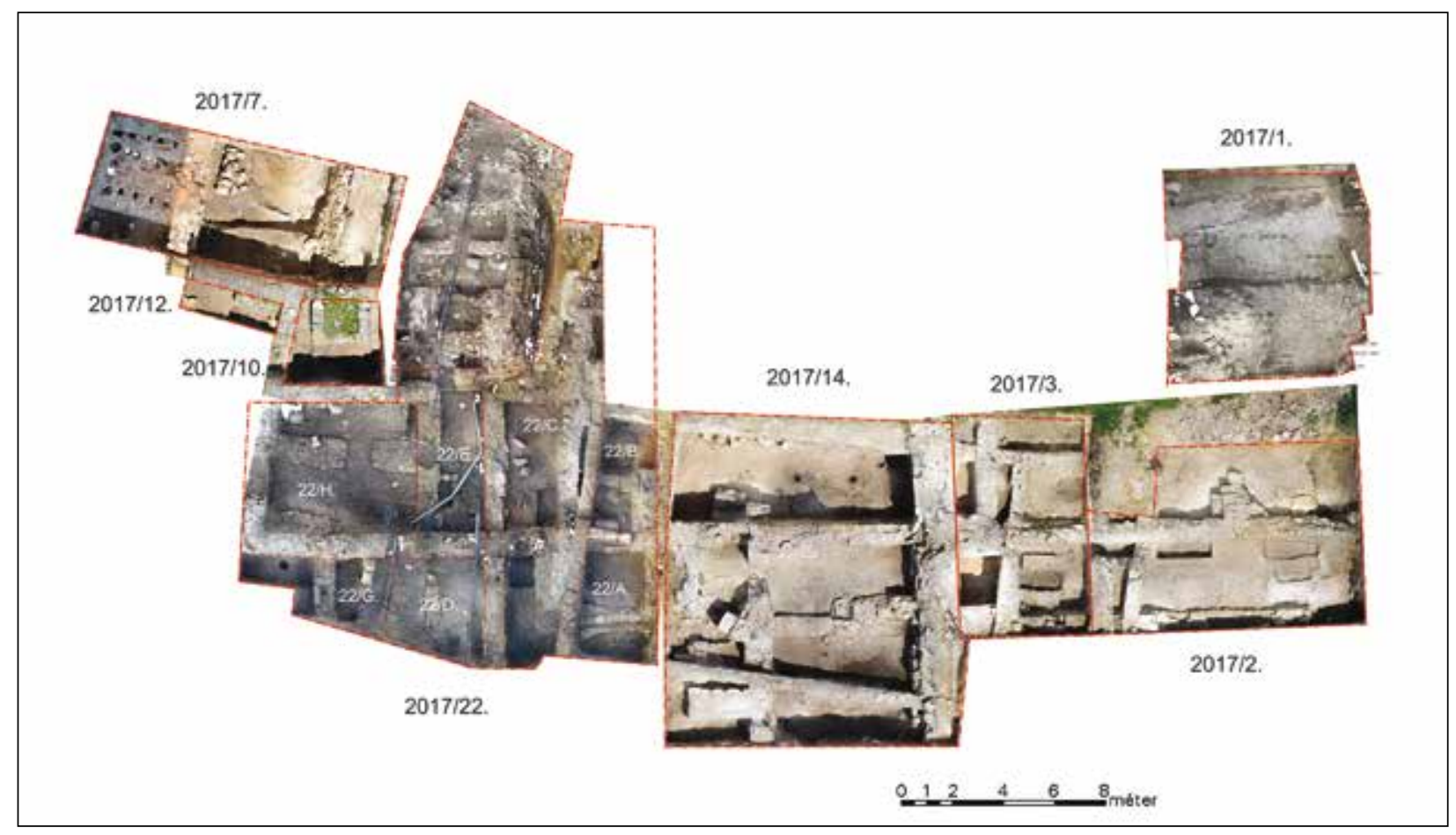

4. kép. A káptalani kolostor északi részének 2017. évi ásatási ortofotója

Fig. 4. Orthophoto of the excavated area in the northern half of the cathedral's cloister cloister 
továbbiakban csak kisebb leletmentésekre, megfigyelésekre volt lehetőség. 2000 körül a székesegyházat és a környező területet súlyosan megbolygatták egy csapadékvíz elvezető rendszer kiépítésével. 2006-ban Fodor László, a Dobó
István Vármúzeum régésze a 4. számú múzeumi épület belsejében egy aknával feltárta a várhegy sziklájába mélyített, úgynevezett dézsmapince bejáratát, és az északi várkapu belső oldalán is nyitott két kutatóárkot. 2013-2015 között a vár-

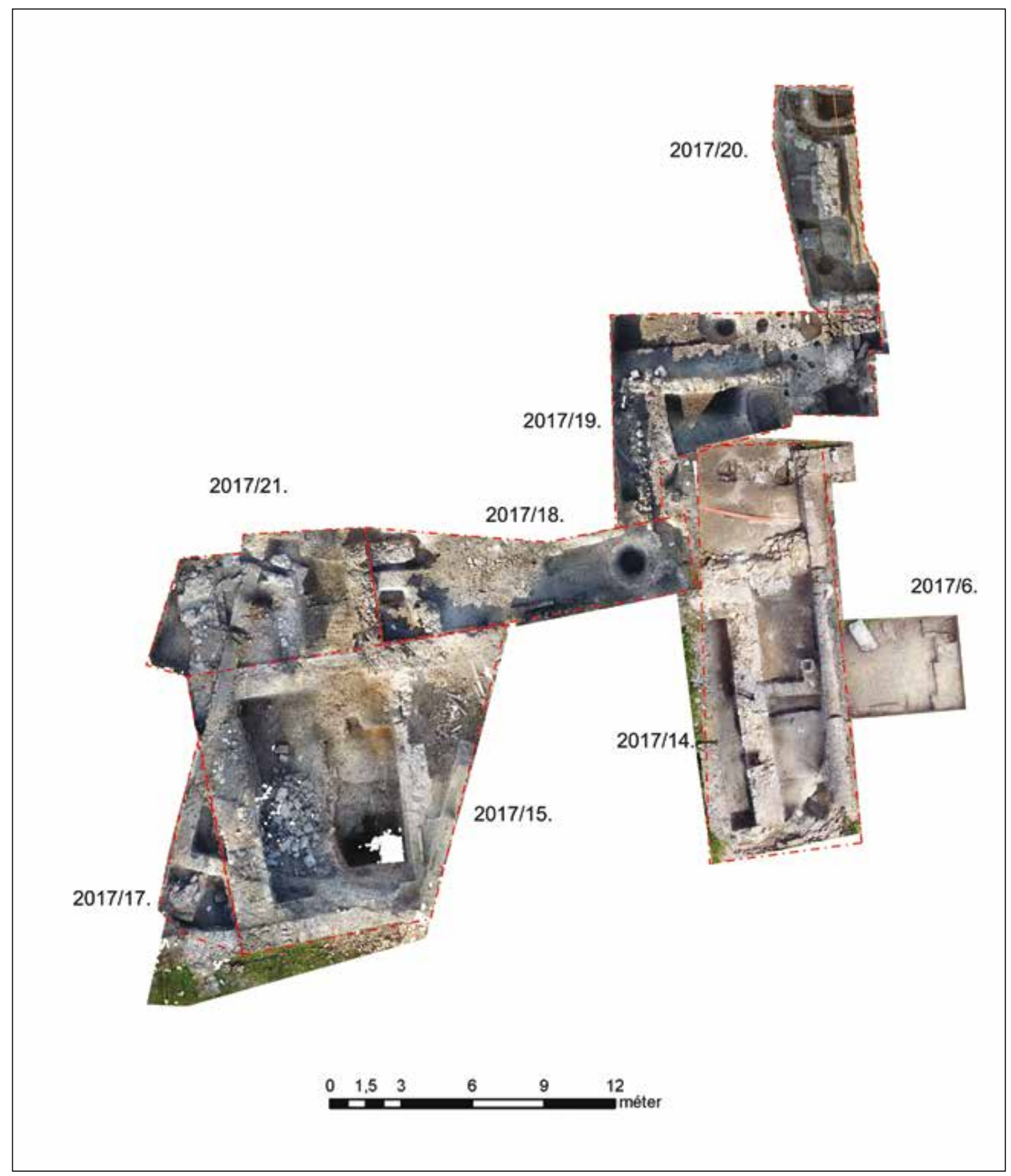

5. kép. A székesegyháztól nyugatra eső terület 2017. évi ásatásának ortofotója

Fig. 5. Orthophoto of the excavated area west of the cathedral, 2017 
múzeum munkatársai: Nagy László, Giber Mihály és Halász Ágoston kezdett újabb jelentős kutatásokba. ${ }^{10}$ 2014-ben a székesegyház előtt hitelesító ásatást folytattak, és egy szelvényt nyitottak az északi várfal belső oldalán, az 1935-ben megtalált középkori épület pincéjében, továbbá felügyelték az északi várkapun belül végzett kábelfektetési munkákat.

\section{A püspöki központ elözményei (12. kép)}

$\mathrm{Az}$ egri vár területén a legkorábbi épületek az 1970-80-as években, Kozák Károly ásatásai során kerültek elő. 1974-1975-ben, majd 1980-81-ben a székesegyház északnyugati tornya előtt egy közel négyzetes alaprajzú, megközelítőleg 9×11 m-es alapterületú, 1 m-es falvastagságú épületet ástak ki (9-10. képek). Megtalálták az épület déli falát, valamint a nyugati falának és az északi fala nyugati felének az alapozását. 2017-ben mi az épület eddig ismeretlen északkeleti részét kívántuk tisztázni. Sajnos e korábban feltáratlan falszakaszt a 2000-ben végzett csatornázási munkák során szinte teljesen elpusztították, de egy falsarkot meg tudtunk fogni, amely elhelyezkedése alapján feltehetően az épület északkeleti sarka lehetett. Az épületnek így csak a keleti falát nem ismerjük, ezt ugyanis a 14. századi templomtorony alapozása teljesen elpusztította. Az azonban Kozák Károly és Nagy László ásatásai alapján bizonyos, hogy a torony belsejében már nem volt nyoma ennek az épületnek. Talán toronyszerú kőépületként rekonstruálhatjuk az építményt. 1980-ban, a középkori székesegyház déli oldalán egy $9 \mathrm{~m}$ átmérôjứ, patkóíves apszisú rotundát találtak (6-7. képek). A rotunda belsejében egy később kiürített, kőlapokból összeállított sírt tártak $\mathrm{fel}^{11}$ (8. kép). Ugyanakkor, a rotundától 52 m-re nyugatra, a korábban feltárt kőépülettól 32 m-re délre, egy legalább $25 \mathrm{~m}$ hosszú palotaépület déli falára is rábukkantak, majd 1982-ben tőle 7 m-re megtalálták az épület északi falának egy szakaszát is (11. kép). Mindhárom feltárt korai kőépület jellegzetes kis méretú, lapos kváderekból épült, amihez hasonló falazásmód jellemzi az abasári udvarház 1040-es évekre keltezhetô rotundáját is. ${ }^{12}$

A rotunda és a tőle északnyugatra álló toronyszerú kőépület, illetve falaik alatt korábbi sírok kerültek elo"13 (6., 9. képek). E sírok egy olyan nagy kiterjedésú temetőhöz tartoztak, amelynek leg-

10 NAGY 2015

11 KozÁK 1990, 333-341.

12 BUZÁs 2017b.

13 A rotunda fala alól előkerült sírokra Halász Ágoston hívta fel a figyelmemet, amelyért ezúton is szeretnék neki köszönetet mondani. korábbi sírjai - mellékleteik alapján - a 10. század végére keltezhetők. ${ }^{14} \mathrm{~A}$ korai épületcsoport tehát egy, már létező temetóre települt rá, de a temetőt ezek felépültét követóen, sőt a későbbi székesegyház felépülte után is tovább használták. Azt semmi sem támasztja alá, hogy e temetô eredetileg is templom körüli temetóként létesült volna, talán csak akkor alakulhatott azzá, mikor a területén később felépült a rotunda.

A rotunda és a tőle nyugatra emelkedő két kőépület a székesegyház és a román kori palota- és káptalani épületek falaihoz viszonyított relatív kronológiájuk alapján a várhegy legkorábbi épületei lehettek (12. kép). A rotunda feltehetően azonosítható azzal a Szúz Mária kápolnával, amelyet Rozgonyi Péter püspök 1430-as oklevele alapján Szent István király alapított és a tatárok pusztítottak el, majd Rozgonyi püspök egy társaskáptalan egyházaként alapította újra. ${ }^{15}$ A téglalap alakú kőépület minden bizonnyal palotaépület lehetett, a közel négyzetes építmény pedig esetleg lakótoronyként értelmezhető. E három épület egy, a 11. század első felében épült udvarházat alkothatott. ${ }^{16}$ Több hasonló udvarházat ismerünk a 11. századi Magyarországról: Visegrád megye dunántúli részén a dömösi udvarházat elsőként I. Béla korában történt esemény kapcsán említették. A későbbi prépostság épületébe belefoglalva került elő az udvarház téglalap alakú kőépülete. ${ }^{17}$ Visegrád megyének a Duna bal parti részén állt a váci udvarház. Erről írott források nem maradtak fenn, épületét azonban a középkori váci székesegyházban folytatott ásatások tárták fel az I. Géza-kori templom nyugati szentélye alatt. Az épületnek két építési periódusát lehetett kimutatni: a téglalap alaprajzú, alápincézett palotát egy második periódusban egy toronnyal bővítve átépítették. ${ }^{18}$ Veszprém megyében a zirci királyi udvarházat említi meg a Képes Krónika I. András király halálának helyszíneként. Az udvarházat teljes egészében

4 A temető feltárásáról: KoZÁK 1979; KOZÁK 1981; KOZÁK 1986.

15 SuGÁr 1984, 149-150.

16 Kozák Károly és Fodor László úgy gondolta, hogy a székesegyház déli oldalán feltárt falak egy, a rotundával egybeépült palota maradványai. (KoZÁK 1984a, 130-131; KOZÁK 1990, 333-341) E falmaradványok azonban sokkal inkább a székesegyház 12. századi oldalkápolnájának falaival azonosíthatók. Ezt igazolja, hogy az épület északi oldalát nem tömör fal, hanem a románkori székesegyház déli mellékhajójába nyíló árkádsor külön, pontszerúen alapozott pillérei alkották. Erről részletesebben lásd alább, a 12. századi székesegyház falmaradványainak leírását.

17 GEREVICH 1983.

18 BuZÁs-KovÁcs 2019, 139. Itt szeretnék köszönetet mondani Batizi Zoltánnak, aki a váci székesegyház és környezet feltárását végezte, és még publikálatlan kutatási eredményeit megosztotta velem. 


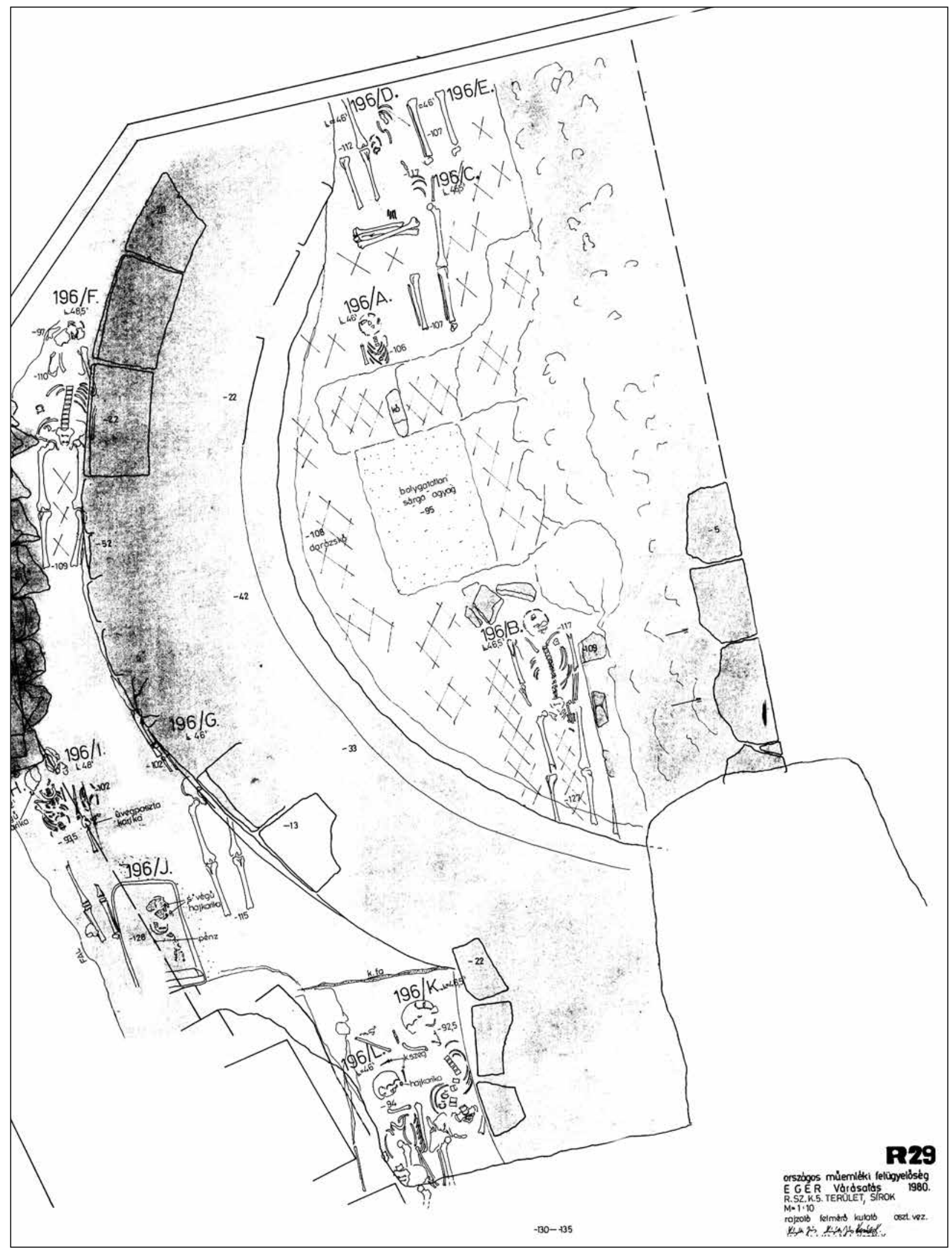

6. kép. A rotunda déli fala alatt és mellett feltárt sírok 1980-as ásatási alaprajza

Fig. 6. Plan of the graves excavated under and beside the rotunda's southern wall, 1980 


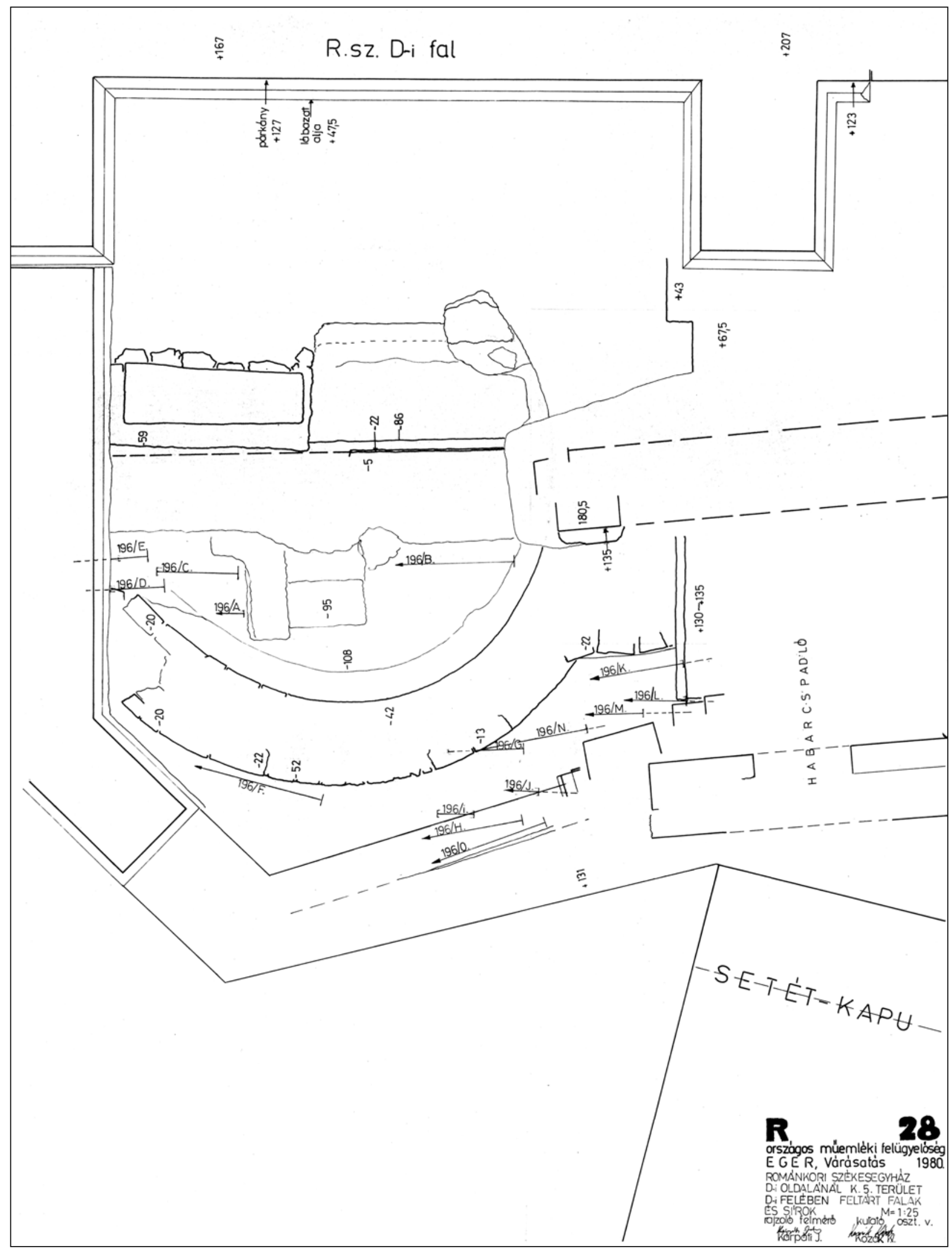

7. kép. A rotunda és a benne feltárt falazott sír 1980 -as ásatási alaprajza

Fig. 7. Plan of the rotunda and the stone-lined grave uncovered inside it, 1980 


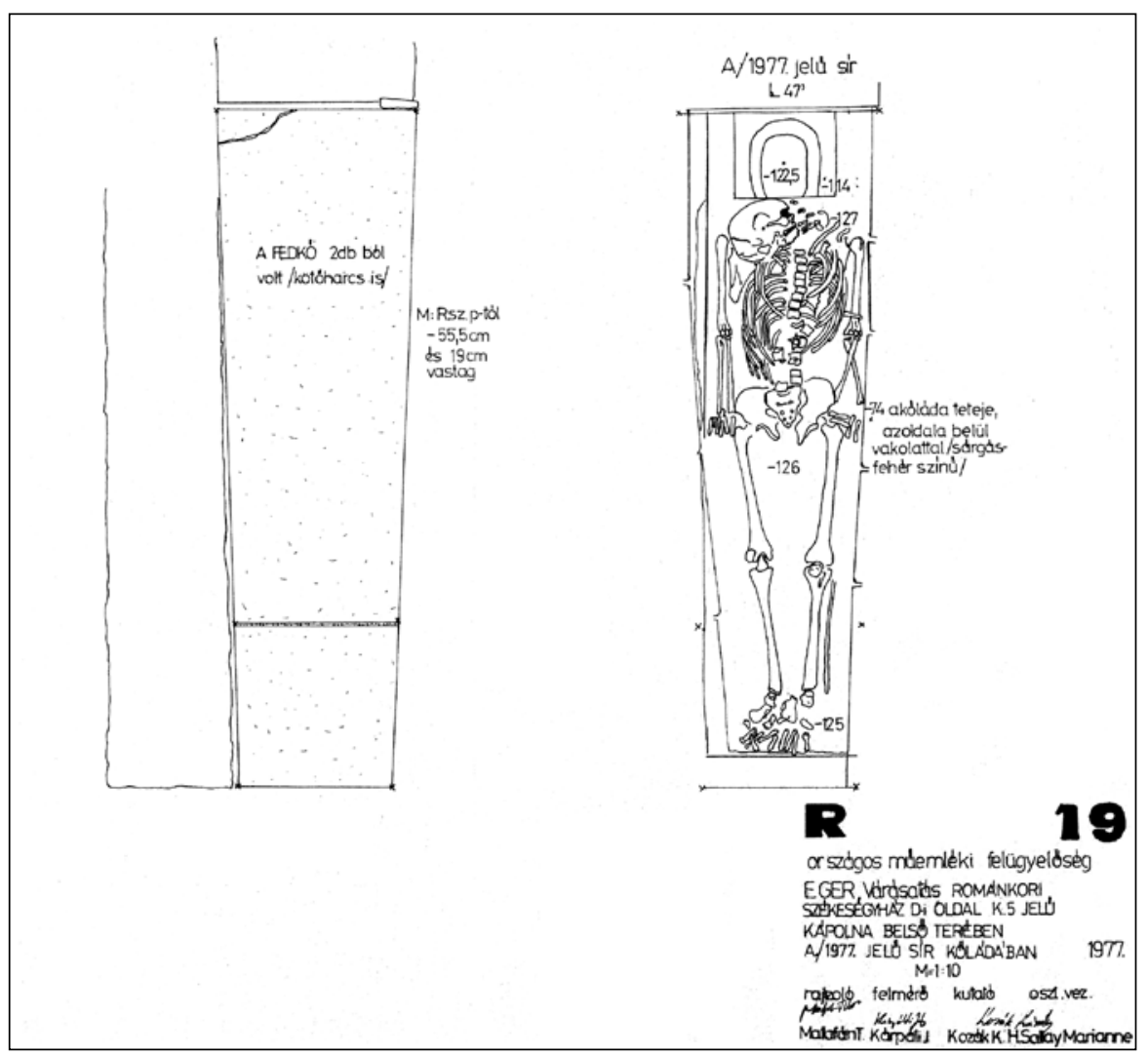

8. kép. A rotundában feltárt A/1977 sír rajza, 1977

Fig. 8. Drawing of Grave A/1977 uncovered inside the rotunda

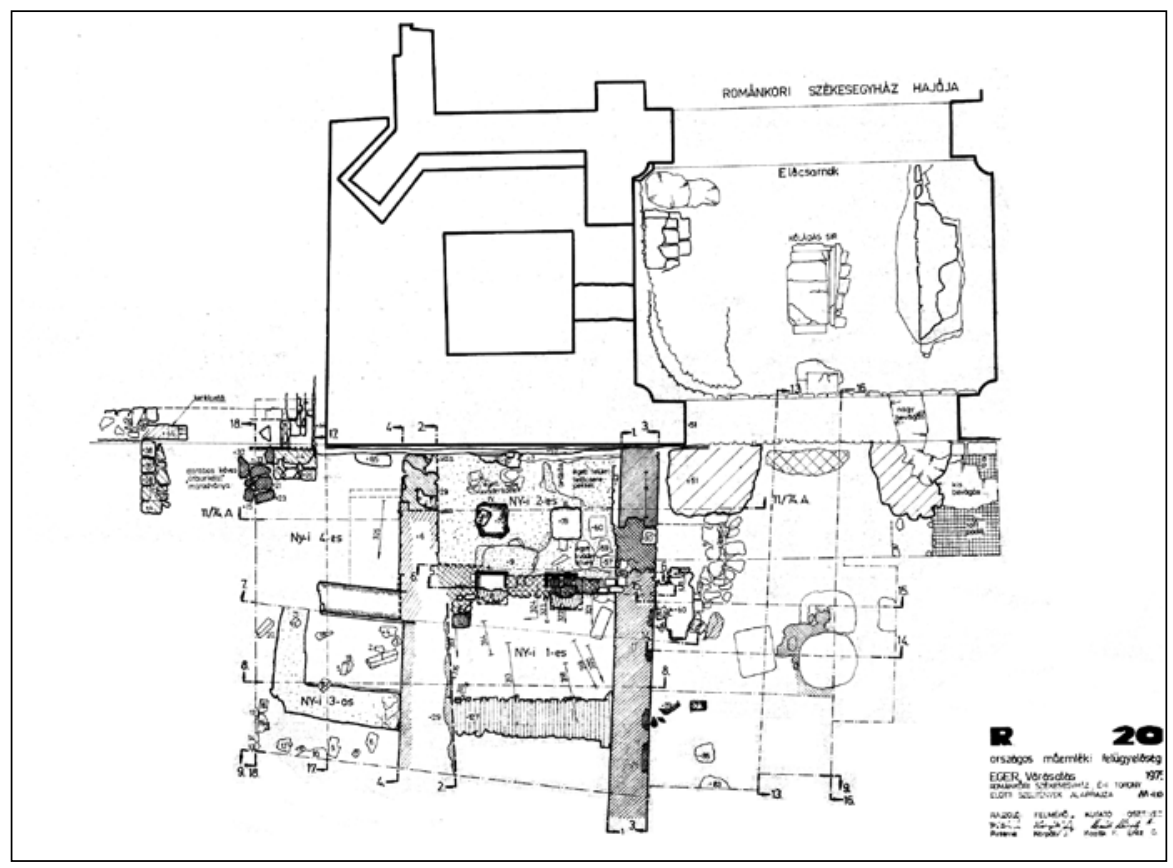

9. kép. A székesegyház északnyugati tornya előtt feltárt több periódusú XI. századi épület 1975-ös ásatási alaprajza Fig. 9. Plan of the 11th century multi-period building in front of the cathedral's north-western tower, 1975 


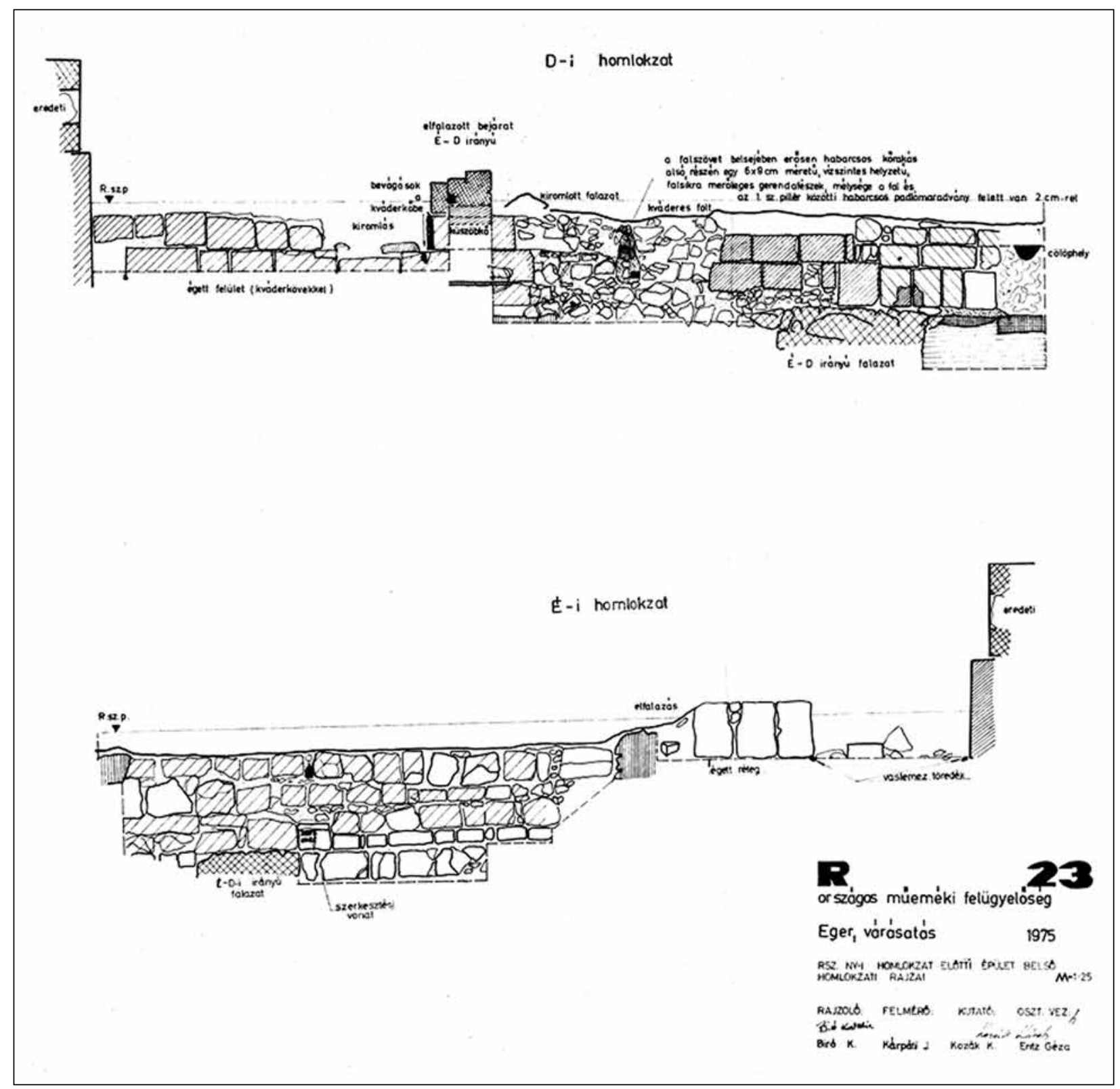

10A. kép. A székesegyház északnyugati tornya előtt feltárt több periódusú XI. századi épület északi és déli falainak külső és belső homlokzatfelmérései, 1975

Fig. 10A. Survey of the outer and inner sides of the northern and southern walls of the 11th century multi-period building uncovered in front of the cathedral's north-western tower, 1975

feltárták, így ismerjük a kétperiódusú palotaépületet, amely eredetileg egy rövidebb téglalap alakú épület volt, a közelében egy félköríves szentélyú templommal, majd a régi palotarész és a templom közé egy nagyobb helyiséget építettek be. ${ }^{19} \mathrm{Az}$ egrihez leginkább hasonló épületegyüttest Illyédről ismerünk, ahol egy II. András korában említett, de a 12. század végén már bizonyosan létező királyi udvarház maradványait

19 MRT 4, 263-266. tárták fel: az udvarház egy rotundából, egy téglalap alakú palotaépületból és egy 10×10 m-es, 1,5 m-es falvastagságú, kétosztatú toronyszerú épületből állt. ${ }^{20} \mathrm{Az}$ egrihez igen hasonló méretú, és falvastagságú torony az 1060-70-es évekre keltezhetó pécsi püspöki palota lakótornya is, amely egy hosszú téglalap alaprajzú palotaépület egyik rövidebb végéhez csatlakozott. ${ }^{21}$

20 KarczaG-SZabó 2012, 238.

21 BuZÁs 2016, 82-83. 


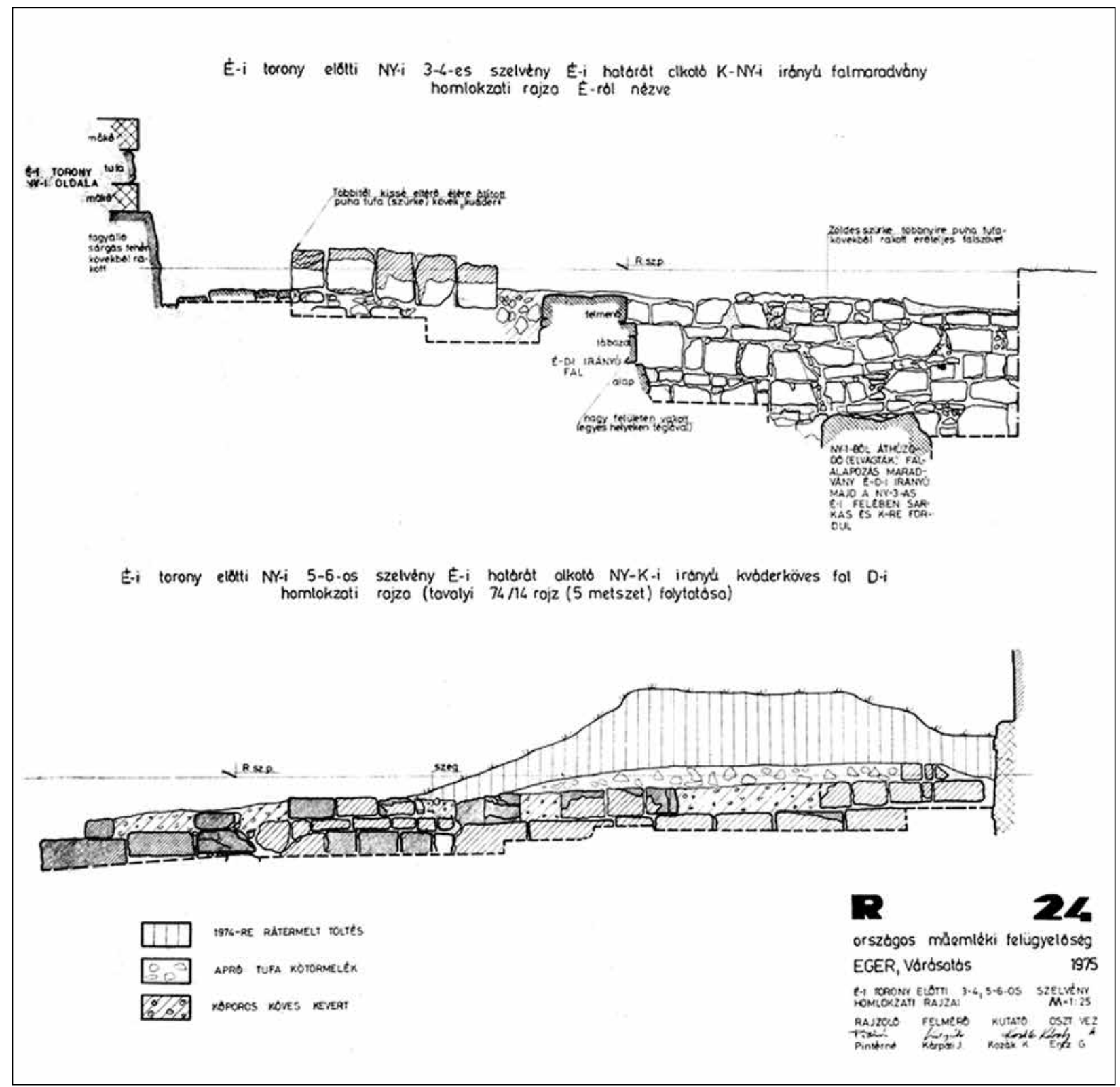

10B. kép. A székesegyház északnyugati tornya előtt feltárt több periódusú XI. századi épület északi és déli falainak külső és belső homlokzatfelmérései, 1975

Fig. 10B. Survey of the outer and inner sides of the northern and southern walls of the 11th century multi-period building uncovered in front of the cathedral's north-western tower, 1975

Az egri püspökség eredete (13. kép)

Az egri udvarház északi, toronyszerú épületének helyére, részben annak falai felhasználásával, nem sokkal később, egy téglalap alaprajzú, négy belső pillérrel tagolt terú épület készült (9. kép). A régebbi épület északi és nyugati falát az átépítés során elbontották, a déli falát pedig egy kváderekből épített falszakasszal meghosszabbították, amely jól láthatóan elvált a régi falszakasztól, mint ezt Kozák Károly 1975-ös felmérése mutatja (10AB. kép). Kozák Károly 1975-ös ásatá- saiból, és az általunk 2017-ben újra feltárt falszakaszból tudjuk, hogy az épület új északi falát - törtkő alapozás felett - kváderekből építették, ám a felmenő fal alsó kvádersora csak a fal keleti részén, illetve a nyugati homlokzat északi végén maradt meg. A nyugati falat szintén Kozák Károly tárta fel 1981-ben, és mi újra kiástuk 2017-ben. Ennek déli végéhez egy kis négyzetes helyiség csatlakozott nyugatról. Ennek kapcsolódását a nyugati fallal egy késóbbi gödör elvágta az északi oldalon (5. kép), de déli fala a kápolna kváderes déli falszakaszának nyugati 


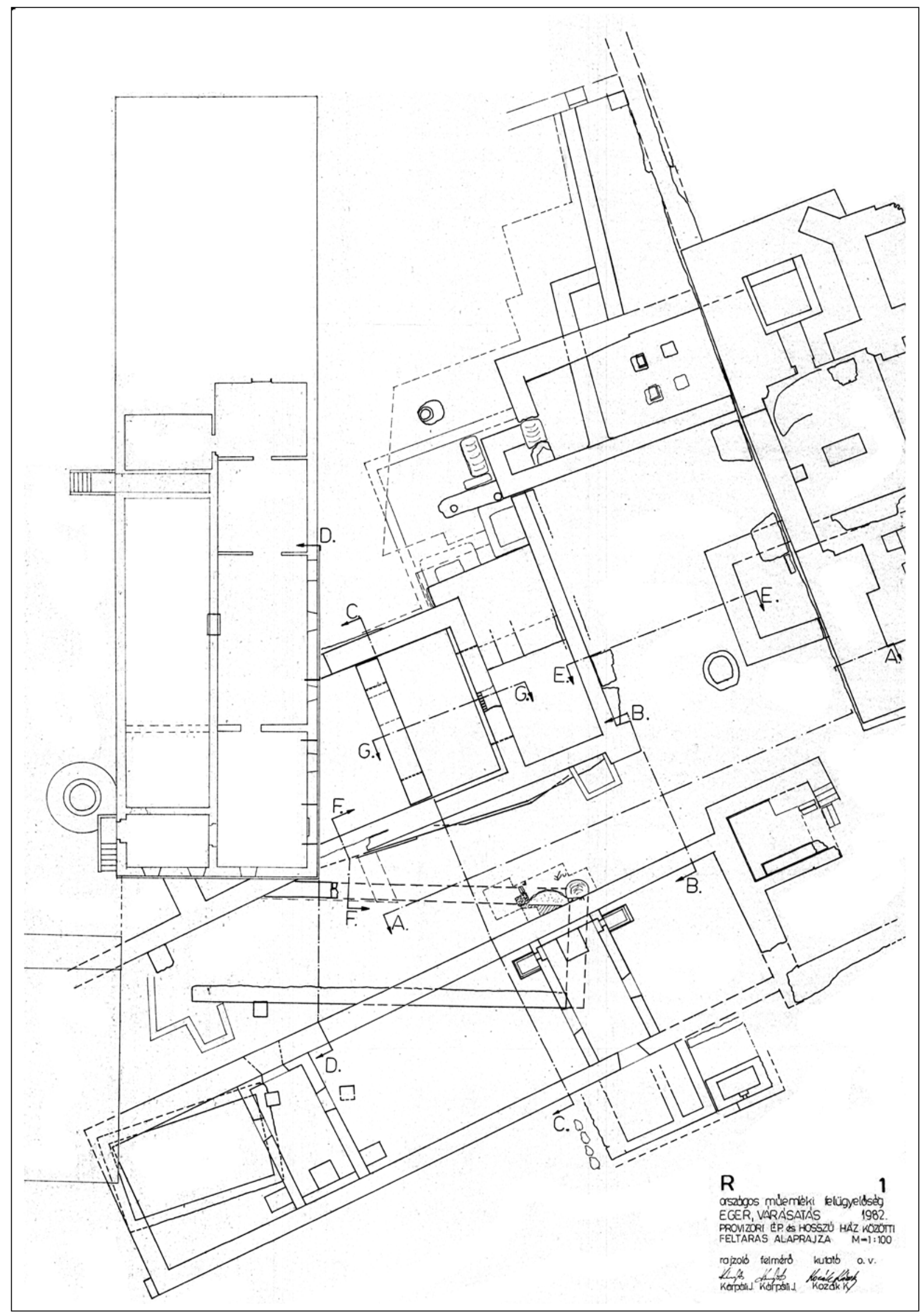

11. kép. A székesegyház nyugati homlokzata előtti terület 1982-es összesített ásatási alaprajza Fig. 11. Plan of the excavated area in front of the cathedral's western façade, 1982 
végével együtt épült, így a helyiség kétségkívül egykorú az épület nyugati meghosszabbításával. Az épület keleti része a székesegyház 14. századi északnyugati tornyának építésekor nyomtalanul elpusztult. Az épület belsejében négy darab, négyszöget formázó, $90 \times 90 \mathrm{~cm}$-es pilléralap került elő az 1975-ös feltárás során. A pillérek KNy-i irányban, egymástól $110 \mathrm{~cm}$, illetve É-D-i irányban $130 \mathrm{~cm}$ távolságra helyezkedtek el. A két nyugati pillér keleti fele a hozzájuk tartozó járószinttól $70 \mathrm{~cm}$-es magasságban maradt fenn. A pillérek faragott kövekból épült, $75 \times 75 \mathrm{~cm}$-es, négyzetes törzse kétlépcsős, rézsüs, faragottkő lábazatról indult. A két pillér lábazata nem teljesen azonos szinten helyezkedett el. A két keleti pillérnek csak az alapozása maradt fenn. Az alapozás tetejét Árpád-kori kerámiát tartalmazó réteg, majd vastag égett tetócserepes, gabonamagvakat tartalmazó réteg fedte. E rétegek ráfutottak az épebben maradt nyugati pillérek lábazatára is.

Feltehetően ehhez az épülethez köthető egy román kori kőfaragvány csoport, amelyet 35×35 cm-es törzsszélességú pillérek, illetve nekik megfelelő falpillérek elemei, továbbá a hozzájuk kapcsolható kiszélesedő lábazat, pillérfejezetek és sakktábladíszes vállpárkányok töredékei alkot-

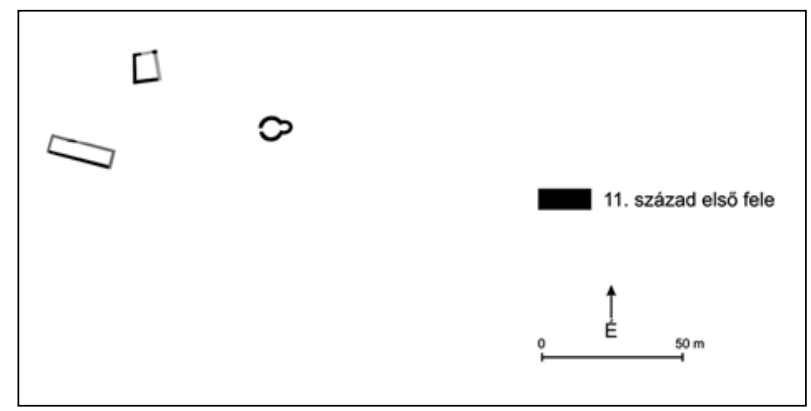

12. kép. Az egri vár helyén állt udvarház első építési periódusa a 11. század első felében

Fig. 12. The first architectural period of the manor house built on the site of the later Eger Castle, from the first half of the 11th century

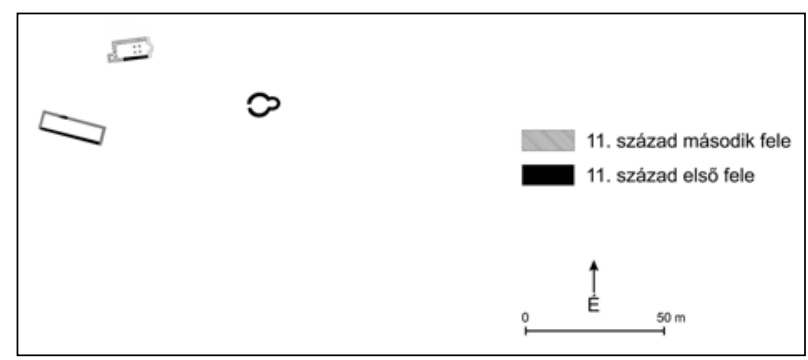

13. kép. Az egri vár helyén állt udvarház és korai püspöki rezidencia a 11 . század második felében.

Fig. 13. The manor house and the early episcopal residence on the site of the later Eger Castle, second half of the 11th century

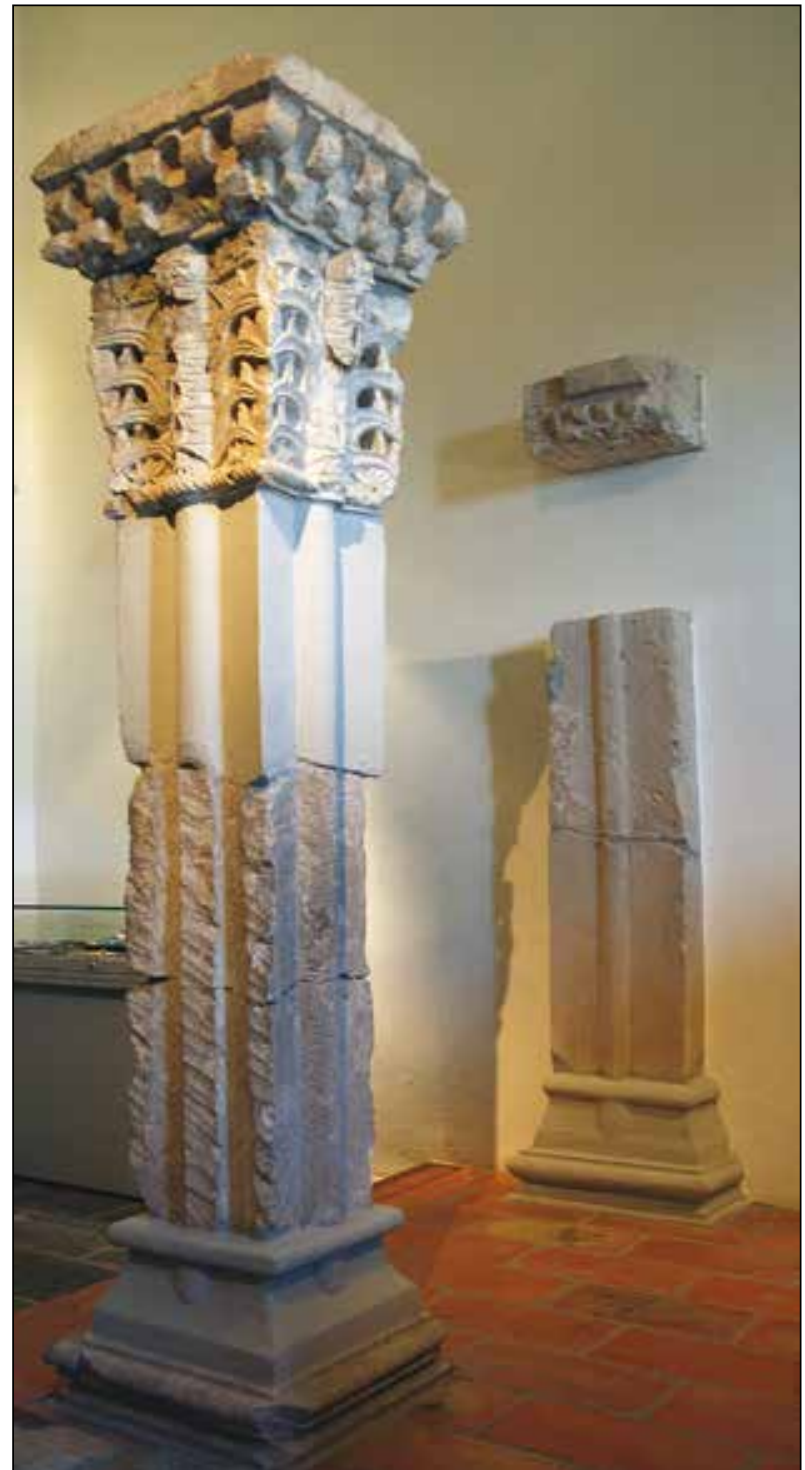

14. kép. Az emeletes kápolna rekonstruált pillére és falpillére a 11. század második feléből a Dobó István Vármúzeum állandó kiállításán

Fig. 14. Reconstructed pier chapel dating from the second half of the 11th and engaged pier from the two-storey chapel from the later 11th century displayed at the permanent exhibition of the Dobó István Castle Museum

nak (14. kép). Ezek a kőfaragványok 1966-ban, a székesegyház déli fala keletről számított harmadik, gótikus támpillérének alapozásából kerültek elő. ${ }^{22}$ A román kori pillérek keltezésre leginkább alkalmazható részletformája a fejezet. A korinthoszi típusú pillérfő csavart díszú asztragál tagozatból indul. A fejezet oldalakat egy-egy nagy méretú akantuszlevél borítja. Az akantuszlevelek külső oldalát háromeres, íves fó- és belólük felfelé tüskeszerúen kiágazó mellékágak alkotják,

22 KozÁK 1975, 90-93. 14. kép; KozÁK-SEdLMAYr 1987, 8-9, 11-12. tétel, 15-17. kép. 
belső oldaluk középeres, váltakozó hosszúságú, lándzsa alakú levélkékból áll. A levelek alatt kis, hegyes, kéteres levelekből álló ötágú palmetták helyezkednek el. A fejlemezt a lentiekhez hasonló palmetták sora díszíti, középen pedig egy-egy hasonló levelekből összeállított rozetta helyezkedik el. A fejezethez mérete szerint pontosan illeszkedő, és azonos lelőhelyről származó vállkövet kétsoros sakktábladísz ékesíti. A pillér sajátos, négyágú csillag formájú keresztmetszete, ahol a csillag szárai között félhenger alakú tagozatok helyezkednek el, tagozásában megfelel a 11. század közepén épült feldebrői felső templom pillérkeresztmetszeteinek, ${ }^{23} \mathrm{csak}$ a tagozatok egymáshoz viszonyított aránya tér el jelentősen. A fejezet díszítése összességében meglehetősen egyedülálló a magyar anyagban, de egyes részletformák több, az 1040-1070-es évek közé keltezhető emlékkel is rokonságba hozhatók: a kis ötágú palmetták legközelebbi párhuzamai az egyik szekszárdi pillérfőn találhatóak meg, ${ }^{24}$ az akantuszlevelek egyszerú formálása pedig némiképp a veszprémi székesegyház 11. századi fejezetének kétágú akantuszleveleivel ${ }^{25}$ állítható párhuzamba, bár a rokonság köztük igen távoli. Fontos hangsúlyozni, hogy az egri fejezet ezeknél az emlékeknél jóval gyengébb kivitelü, bár fantáziadús kialakítású munka. A viszonya a 11. század második felének többi magyarországi faragványával csak igen távoli formai-stiláris kapcsolat, semmiképpen sem múhelyközösség.

A faragványok lelőhelye - a székesegyház gótikus támpillérének alapozása - a tatárjárás utáni, 13. század közepi átépítés során épült, ami arra vall, hogy a benne talált 11 . századi faragványokat tartalmazó épület is a tatárjárás idején pusztulhatott el. Az egri várban a 13. századnál korábbra datálható, szabadon álló, kis méretú pillérek egyetlen helyről ismertek: a székesegyház nyugati tornya előtt feltárt négypilléres épületból. Ennek pillérei ugyan egyszerúbb - hasáb alakú - és kétszer olyan széles törzzsel készültek, és falpillérei sincsenek, ám az épület falvastagságai és a délnyugati sarkához csatlakozó, valószínúleg lépcsőtoronyként értelmezhető helyiség alapján alighanem emeletes lehetett. Így lehetséges, hogy a fent tárgyalt 11 . század második feléból származó kis pillérek az emeleti szinten, a földszint vaskosabb hasáb alakú pillérei felett állhattak, falpillérek pedig az emelet vékonyabb falai miatt a földszinti falakat lezáró padkára támaszkodhattak. Az így rekonstruálható négypilléres, emeletes kápolnaforma a 11. század máso-

\footnotetext{
23 Tóth S. 1998, 1. kép.

24 BuZÁs 2010, 39-40. képek.

25 То́тн S. 1994, 57, I.7. kép.
}

dik felétől egy-másfél évszázadon át a fópapi, uralkodói és fő́ri rezidenciák egyik jellegzetes kápolnatípusa volt Európa számos területén. A típus legkorábbi ismert példája a kölni érsekek Evangelista Szent Jánosnak szentelt palotakápolnája, amely a dóm keleti keresztházához csatlakozva épült még 1025 előtt. Az egrihez leginkább a goslari Liebfrauenkirche hasonlít, amelyet a császári palota kápolnájaként szenteltek fel feltehetóen 1058-ban. Ennek alaprajza ugyanis az egrihez hasonlóan nem négyzetes, hanem téglalap alakú, amelyen belül a négy pillér a keleti részben helyezkedik el. ${ }^{26}$

Az egri püspökség alapításáról és korai történetéról szóló eredeti oklevelek a tatárjárás idején elégtek, ezét 1261-ben Lampert püspök IV. Béla királyhoz fordult, hogy foglalja írásba az egri egyház jogait. Ez az irat V. István király 1271-ben kiadott oklevelében szereplő átiratból ismert. Ennek szövege szerint: a „legszentebb János apostolnak és evangélistának szentelt egri anyaszentegyház, amelynek alapitója és adományozója István, Magyarország elsó királya volt". ${ }^{27}$ A 13 . századi oklevél, bár kétségkívül hiteles, ám tartalma a régebbi oklevelek pusztulása miatt csak bemondáson alapulhatott. Ezért a püspökség Szent István általi alapításának állítása nem állhat minden vitán felül, hiszen a 13. századra már általános gyakorlatnak számított számos intézmény részéről, hogy tekintélyüket és jelentőségüket azzal támasszák alá, hogy alapításukat a szent királyokra, lehetőleg Szent Istvánra vezetik vissza. A Szent István-i alapítást kimondó forrás kései mivolta azért különösen nagy probléma, mert az első egri püspök említése csak jóval a Szent István király uralma utáni időből, a 11. század második feléből ismert. A liège-i Szent Lambert székesegyház káptalanjának nekrologiumában fennmaradt bejegyzés szerint november 12-én hunyt el Liduinus, egri püspök. ${ }^{28} \mathrm{Az}$ adat hitelességét támasztja alá, és keltezését segíti, hogy Liduinus személye feltúnik egy kevéssel 1064 után lejegyzett namuri krónikában is, csakhogy az ebben szereplő Lieduinust ott bihari püspök-

26 A fôpapi kápolnák közül a kölni keltezését az teszi lehetővé, hogy az 1020-1025 körül készült kölni Hillinus-Codex dedikációs képén megjelenő székesegyház-ábrázoláson már szerepel (WoLf 1971). A speyeri és herefordi püspöki kápolnák a 11. század utolsó harmadában, a mainzi Szent Gotthárd kápolna 1137-ben épült. A kápolnatípusról összefoglalóan: STEVENS 2003, 73-94.

27 „sancta mater ecclesia Agriensis in honorem beatissimi Iohannis apostoli et ewangeliste dedicata, cuius fundator et donator sanctissimus rex Stephanus primitivalis regni Hungarie...fuit" (SZENTPÉTERY 1943, 2123, 119).

28 "Commemoratio fratris nostri Liduini Agrensis episcopi" (SZÉKELY $1972,59-60)$ 
nek mondják. E krónika szerint a lotaringiai származású püspök eljött Pannóniából Liège-be, hogy lássa övéit. ${ }^{29} \mathrm{Ez}$ utóbbi forrás egyúttal a bihari püspökség elsó és egyetlen említése is. ${ }^{30}$ Liduinus személyében tehát összekapcsolódik az egri és bihari püspökség története. Ebben a korszakban még nem volt gyakorlat a püspökök áthelyezése egyik egyházmegyéből egy másikba. ${ }^{31}$ A püspök kétféle titulusát legutóbb Koszta László próbálta meg oly módon magyarázni, hogy Liduinus egyszerre viselte volna az egri és a bihari püspöki tisztséget is. Ráadásul Koszta úgy gondolta, hogy a bihari egyházmegye megalapítására csak 1048-ben, Béla herceg bihari dukátusának létrehozásával párhuzamosan kerülhetett sor, és az új egyházmegye első püspöke maga, az ebben az idóben Magyarországra érkező Liduinus volt. Valójában azonban elég kevéssé látszik indokoltnak azt feltételezni, hogy 1048ban I. András kiszakította volna a bihari egyházmegyét az egriból, de az új egyházmegye élére mindjárt ugyanazt a személyt helyezte volna, akit az egri egyházmegye élére is tett. Sokkal logikusabb azt feltételezni, hogy az egri és a bihari püspökség megnevezése a forrásokban valójában ugyanazt az egyházmegyét jelenti két, egymást váltó székhellyel. Hasonló esetról van más példa is Magyarországról, ráadásul nem is túl távoli időből. Igy történt ugyanis a kalocsai-bácsi egyházmegye esetében, amely Szent István korában kalocsai székhellyel jött létre, majd központját Szent László Bácsra helyezte, de a 13. századtól újra Kalocsa került előtérbe, hogy a 15. század második felében pedig megint Bács legyen az érseki székhely. Ezt a logikus értelmezést az akadályozta meg mindeddig, hogy Pray György óta a legtöbb kutató a bihari püspökséget a váradi egyházmegye elődjeként határozta meg, a kettő között lényegében egyenlőségjelet téve, mindöszsze Szent László korától a püspöki székhely megváltozásával számoltak. ${ }^{32}$ Pedig ezt az értelmezést a középkori források nem támasztják alá. A váradi püspökség történetének legfontosabb forrásai a 14. században lejegyzett váradi káptalani statútumok egyértelmúen fogalmaznak: a váradi egyházat Szent László király alapította, először társaskáptalanként, majd püspökséggé emelte. ${ }^{33}$ Szó sem esik arról, hogy a püspökség már korábban is létezett volna más székhellyel, és László pusztán a központját helyezte volna Váradra. Ha Szent László pusztán a bihari püs-

\footnotetext{
29 То́тH P. 2007, 545.

30 KoszTa 2014.

31 KosZTA 2013, 16

32 BunYITAI 1883, 3-5; KoszTA 2014, 42-46.

33 BunYITAI 1883, 22-46; KosZTA 2014, 41.
}

pökség új székhelyeként alapította volna meg a váradi székesegyházat, akkor erről a székesegyház kanonokjainak a 14. században is minden bizonnyal tudniuk kellett volna, és ezt aligha hallgatták volna el, hiszen így nemcsak egy, hanem mindjárt két szent királyt is az alapítóik között sorolhattak volna fel: Szent Istvánt mint az egyházmegye és Szent Lászlót mint a székesegyház fondátorát. Ezek szerint viszont nem erről volt szó, hanem arról, hogy a váradi egyházmegyét Szent László újonnan hozta létre, mégpedig olyan módon, hogy területét kiszakította a korábbi, nagy területú egri-bihari püspökségből, és Várad központtal önálló püspökséggé szervezte. ${ }^{34} \mathrm{~A}$ váradi püspökségnek az egri-bihariból való utólagos kiszakítását igazolja a Fehér-Körös menti zsombolyi fóesperesség esete is, amely az egész középkorban megmaradt az egri püspökség fennhatósága alatt, bár Várad alapítása után már területileg nem érintkezett az egri egyházmegyével. ${ }^{35}$ Ezek szerint bízvást elfogadhatjuk a váradi káptalan értesülését a váradi püspökség Szent László által történt alapításával kapcsolatban.

Továbbra is kérdés marad azonban az egri-bihari püspökség alapításának és a püspöki székhely áthelyezésnek időpontja. A nagy kiterjedésú egyházmegye területe lényegében a bihari hercegség területét foglalhatta magába, ${ }^{36}$ így joggal feltételezhető hogy alapítása összefügg a bihari dukátus létrehozásával. A dukátusról a Képes Krónika úgy fogalmaz, hogy az I. András király és Béla herceg közti országmegosztás „Magyarország első felosztása hercegei és királyai között viszálykodásokés hadakozások magva lett" ${ }^{37}$ A dukátus helyére az egyetlen utalást a Képes Krónikában leírt, András király és Béla herceg közti várkonyi találkozó helyszíne tartalmazza. Várkony, a mai Tiszavárkony, Szolnok alatt, Bihar és Esztergom között félúton, a Tisza mentén helyezkedik el. Ennek alapján joggal feltételezhetjük, hogy Béla herceg dukátusának központja a Tiszántúlon, Bihar megye területén lehetett. Több történész számol azonban a bihari dukátus valamilyen

34 Ezt a véleményt képviselte a váradi püspökség monográfusa: BUNYITAI 1883, 29-35.

35 KANDRA 1883; KoszTA 2014, 80. Egy új egyházmegye alapításához egy már meglévő területén az illetékes püspök jóváhagyására volt szükség. A zsombolyi főesperességhez viszont minden bizonnyal azért ragaszkodott az egri püspök, mivel a területén átfolyó, az erdélyi érchegység bányáinál eredő Fehér-Körös - mint fontos gazdasági útvonal - jelentős jövedelemforrás lehetett számára.

36 KoszTA 2014, 67. jegyzet. Megállapításait ugyan csak a váradi püspökség területére érti, de éppúgy érvényesek az egri püspökség területére is.

37 KRISTÓ 1974, 40. 
korábbi előzményével is. ${ }^{38}$ Erre utalhat esetleg Imre herceg halálos vadászbalesetének helyszíne a bihari Igfon erdőben. Sajnos Bihar várának ma még jobbára ismeretlen építéstörténete nem segít a kérdés tisztázásában. ${ }^{39}$

Az egri-bihari püspökség területén - a Dunántúllal, a Délvidékkel, Dél-Erdéllyel és a Felvidékkel ellentétben - nem léteztek államalapítás előtti keresztény hagyományok, így ott a keresztény térítés is sokkal lassabban folyhatott. Ennek következtében az államalapítás korában jó ideig még nem lehetett sem indokolt, sem lehetséges szabályos egyházszervezet létrehozása. ${ }^{40}$ Am éppen a keresztény hagyományok hiánya okozhatta Szent István korától a területen a keresztény térítő tevékenység királyi támogatását és akár egy püspökség létrehozását is, amely azonban - a missziós püspökségekhez hasonló módon - kezdetben még nem biztos, hogy szilárd székhellyel rendelkezett. ${ }^{41} \mathrm{E}$ misszió legalább egyik bázisa feltehetően az egri udvarház lehetett, ugyanis az udvarház melletti kápolnának a 11. század első felében már kétségkívül múködő keresztény temetője régészetileg is igazolja, hogy ezen a helyen mindenképpen jelentős keresztény térítő tevékenységgel kell számolnunk. Az egri Szúz Mária kápolna Szent István-i alapítására vonatkozó 15. századi helyi egyházi hagyomány pedig arra utal, hogy ez a keresztény térítés kifejezetten Szent István korára nyúlik vissza Egerben. Így joggal vethetô fel, hogy az a 13. században lejegyzett egyházmegyei hagyomány, amely Szent István királyhoz kötötte az egri egyház alapítását, megfelelt ugyan a valóságnak, de valójában nem egy Szent István-kori egri püspökség, hanem egy, a 13. században már régóta egrinek nevezett egyházmegye területén múködő, annak jogelődjét jelentő, de számunkra ismeretlen nevŭ, Szent István-kori püspökség alapítására, és emellett talán e püspökség szintén Szent István-kori egri missziós központjára is vonatkozhatott. Eme korai egyházmegye első szilárd székhelyének létrehozása viszont nem Egerben, hanem Bihar várában, a bihari dukátus megalakításával kapcsolatban történhetett meg, egyelöre számunkra ismeretlen időpontban, de mindenképpen még a 11. század első felében. Az egyházmegye élére - talán az 1046 őszén kitört pogánylázadás idején mártírhalált halt korábbi püspök helyett ${ }^{42}$ -

38 KRISTÓ 1974, 40-48.

39 A bihari várról legutóbb összefoglalóan: MoRDOvin 2016, CD melléklet -Katalogus/0067_bihar.html.

40 KoszTA 2014, 46-53.

41 Hóman 1921, 200; Hóman 1938, 168.

42 A Szent Gellért legenda szerint Gellért püspök egyik vértanú társa egy Budi nevú püspök volt (SRH II, 501-503). A Váradi Regestrumban fennmaradt egy 1214. évi Bihar vármegyei per
I. András király az ekkor Liège-ből Magyarországra érkező, lotharingiai származású Liduinust állította. Liduinus Magyarországra kerülése öszszefügghet azzal, hogy a lotharingiai források szerint 1047-1048-ban nagyszámú tournai-i és liège-i polgár és egyházi személy menekült Magyarországra a hazájukban dúló háború és éhínség elől..$^{33}$ Liduinus későbbi liègei utazásának időpontját nem ismerjük, csak annyit tudunk, hogy az erról hírt adó krónika az 1064 utáni években, feltehetően 1067 körül készült. ${ }^{44}$ Liduinus halálának időpontja is kérdéses. ${ }^{45}$ A Képes Krónika szerint 1068-ban az országra töró kunok (valójában úzok) ${ }^{46}$ Bihart is lerohanták, sôt egy kun vitéz a váradi püspök lányát el is rabolta, akit László herceg szabadított ki. ${ }^{47}$ A váradi püspök említése itt nyilvánvalóan anakronizmus, hiszen a váradi püspökséget László csak jóval később, feltehetően halála évében, 1095-ben alapította. A kései krónikás nyilván a számára már értelmetlennek hangzó bihari püspök megjelölés helyett használta a Bihar melletti Várad püspökének megjelölését. Valószínúnek tưnik, hogy az úz támadás miatt költözhetett át Liduinus püspök Biharból a biztonságosabb Egerbe. Esetleg ebben az időben épülhetett fel itt a korábbi lakótorony helyén az emeletes kápolna, amit az ide települő püspök palotakápolnaként használhatott, míg a rotunda az ideiglenes székesegyház szerepét tölthette be (13. kép). Mivel Liduinus egri püspökként halt meg,

jegyzőkönyve, ahol említenek két tanút, akiket „de genere episcopi Budlu"-ként határoznak meg. (Váradi Jegyzőkönyv/ Regestrum Varadinense [1208-1235] Arcanum Adatbázis Nr. 97. [323] https://www.arcanum.hu/hu/online-kiadvanyok/Varadi-varadi-jegyzokonyv-regestrum-varadinense-1208-1235-2/ textus-90/testimonia-regestri-varadiensis-ordine-chronologico-digesta-D6/annus-1214-1AE/ nr-97-323-208/). Pauler Gyula elutasította a Szent Gellért legendában említett Budi - akinek a nevét ő a Bődnek értelmezett Buldi néven idézte - azonosítását a Váradi Jegyzőkönyv Budlu püspökével. Érvelése az Anonymusnál említett "portus beuldu" azonosításán alapult a bődi révvel, ami szerinte amellett szól, hogy a Bu(l)di név nem azonosítható egyértelmúen a Budlu névvel (PAULER 1899, I, 423, 188. jegyzet). Győrffy György késóbb viszont - Budli néven említve a Szent Gellért legenda mártír püspökét - azonosnak tekintette Budlu püspökkel, és ennek alapján Budit bihari püspöknek tartotta (GYÖRFFY 1984, 795, 846).

43 То́тн Р. 2007, 543-544.

44 Tо́тн P. 2007, 545; Koszta 2014, 43.

45 Koszta László szerint Liduinus már 1067-ben sem élt, ugyanis a százdi alapítólevél méltóságsorában nem szerepel ilyen nevú püspök, pedig mint illetékes megyéspüspöknek neki ott kellett volna lennie a monostor alapítólevelének kiadásánál (KosZTA 2014, 62). Ennek azonban más oka is lehetett, így például a püspök távolléte, például ekkor akár éppen szülőföldjén, Liège-ben is tartózkodhatott.

46 Kiss 2007, 560-563.

47 SRH I, 368. 


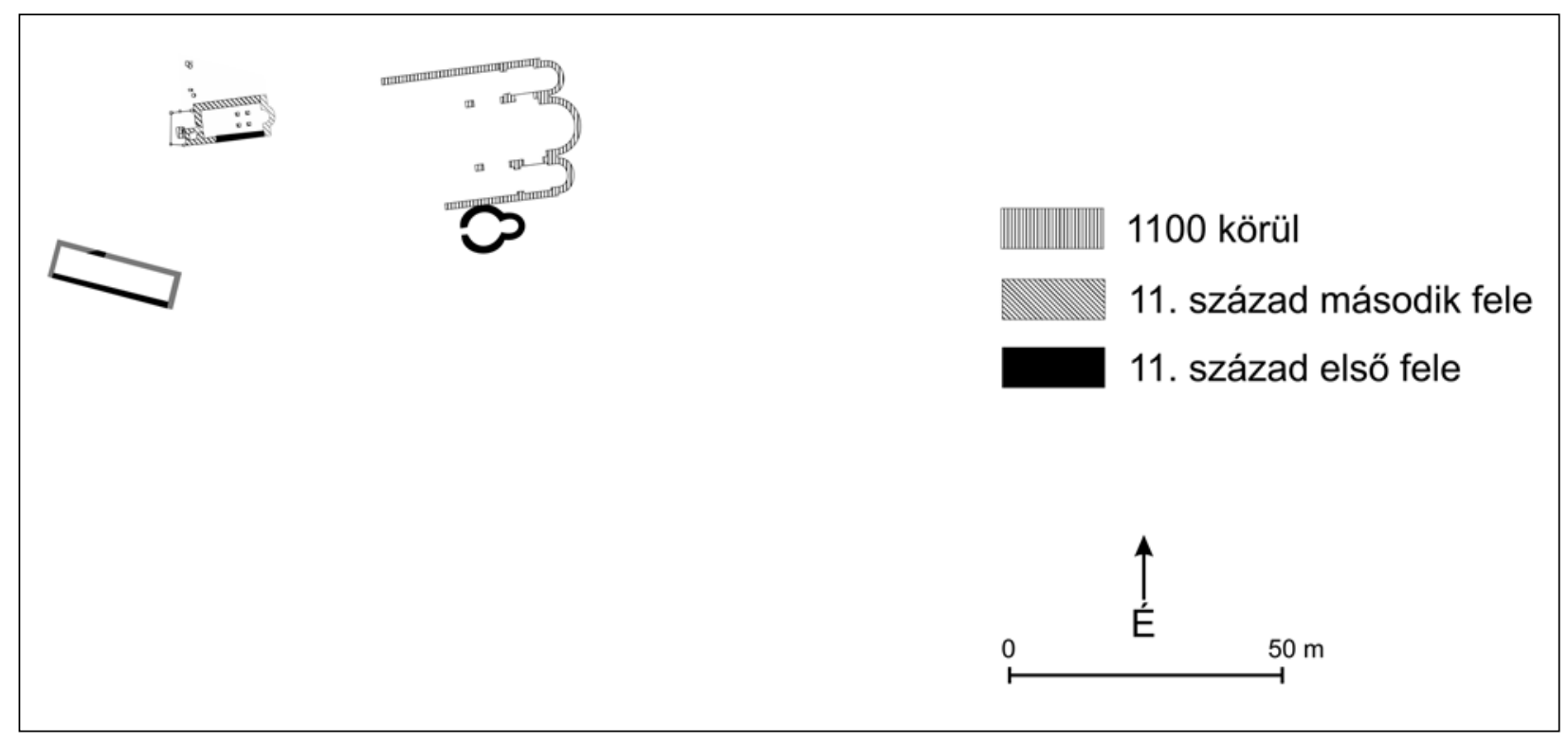

15. kép. Az egri püspöki központ a 12. század elején

Fig. 15. The episcopal seat in Eger in the early 12th century

feltételezhető, hogy Egerben is temették el. Talán az ő sírja lehet az a fejtámaszos, kőlapokból kialakított sírhely, ami a rotunda hajójának közepén került elö ${ }^{48}$ (7-8. képek).

\section{A püspöki központ rögzülése Egerben (15. kép)}

Liduinus püspök székhelyváltoztatása mindenképpen ideiglenes lehetett. Halála után Géza és László hercegek a püspökség központját visszahelyezhették saját székhelyükre, a bihari várba. A Képes Krónika ugyanis Salamon király és Géza herceg viszálya kapcsán elmondja, hogy az 1073-as esztergomi találkozójuk után túszokat cseréltek, és Géza ekkor többek között a váradi püspököt küldte Salamonhoz. ${ }^{49}$ A váradi püspök említése természetesen ez esetben is anakronizmus, de a fenti megfontolás alapján itt is a bihari püspököt érthetjük e megjelölés alatt. Az egri püspöki cím említése újra csak egy 1095-ös esemény kapcsán tûnik fel a Képes Krónikában. Szent László ekkor unokaöccsét, Kálmán herceget egri püspökké kívánta tenni, ám amikor ez Kálmán tudomására jutott, Lengyelországban

$48 \mathrm{Az}$ „A/1977” jelú sír 1977-ben teljes épségben került elő. A két díszítetlen, de faragott kőlappal fedett és kőlapokból összeállított sírban nem kerültek elő mellékletek, csak egy, a fej formájának megfelelően öblösen kifaragott kő fejtámasz. Kozák Károly: Eger Várásatás, Jelentés 1977. 2-3, VI-IX. fényképes tábla, 10 rajz. Dobó István Vármúzeum, Adattár. A csontok természettudományos vizsgálata minden bizonynyal új adatokat szolgáltathatna a halott azonosításához.

49 SRH I, 378-379. Az időpontra: PAULER 1899, I, 122. menekült. ${ }^{50}$ 1095-ben az egri-bihari püspökség székhelye tehát már újra Egerben volt. Az átköltözésre minden bizonnyal akkor kerülhetett sor, mikor 1091-ben az Erdélyen át az országba betörő kunok Bihart is feldúlták. ${ }^{51}$ A visszaköltözés azonban ezután már elmaradt. Ebben az időben ugyanis Bihar már nem volt a hercegség székhelye: Álmos herceget László király az 1091-ben meghódított Szlavónia élére állította, Kálmánt pedig egyházi pályára szánta. ${ }^{52}$ Lényegében Bihar helyett hozhatta létre a közelben Váradot, de itt először még csak egy társaskáptalant alapított, amint azt a váradi statútumokból tudjuk. A Képes Krónika később arról ír, hogy Kálmán - királysága előtt - váradi püspök volt. Ezt az értesülést erősíti meg a zágrábi és a váradi krónika is. ${ }^{53}$ Ezek az adatok csak úgy értelmezhetők, ha feltételezzük, hogy mikor Kálmán, László király hívására visszatért Lengyelországból, és hajlandó volt elfogadni a László által korábban felajánlott püspöki címet, már foglalt volt az egri püs-

50 A Képes Krónika Kálmán egri püspökké történő kinevezésének tervét és a herceg ezzel indokolt elmenekülését László tervezett cseh hadjáratának idejére teszi (SRH I, 418-419), ami 1095-ben történt (PAULER 1899, I, 173-174). Győrffy György azonban önkényesen, a krónika szövegétől eltérően értelmezve az eseményeket, Kálmánt már korábban felszentelt és hivatalt viselő váradi püspöknek tekintve, Kálmán lengyel emigrációját László és IV. Henrik 1093-as szövetségkötésével, és II. Orbán pápával való szembefordulásával hozta kapcsolatba (GYÖRFFY 1984, 937-938).

51 PAULER 1899, I, 157-160.

52 KRISTÓ 1974, 105.

53 KoszTa 2014, 62-63. 
pöki szék. Így László kifejezetten Kálmán számára kiszakított egy új püspökséget az egri egyházmegye területéból, amelynek székhelyévé a nem sokkal korábban, általa létrehozott váradi egyházat tette meg. A Kálmán szökése után Szent László által kinevezett egri püspök személyét nehéz azonosítani. A 18. századi eredetú egyházmegyei hagyomány egri püspöknek titulálja a 12. században lejegyzett pozsonyi évkönyvekben az 1100-as évnél a kunokkal szembeni harcban elesettként említett Cupanus (Koppány) püspököt. Koppány püspök halála szerepel a Képes Krónikában és Jan Długos 15. századi lengyel krónikájában is, ${ }^{54}$ ám egyik középkori forrás sem említi, hogy melyik egyházmegye élén állt, így bár Koppány püspök személyének létéhez nem fér kétség, egri püspök mivoltát semmi sem támasztja alá. Más szempontból nem tekinthetó teljesen hitelesnek egy bizonyos Prokopius egri püspökre vonatkozó adat. Ót egy 1102-es keltezésú zárai oklevél említi mint egri püspököt, ${ }^{55}$ ám ez az oklevél hamisítvány. Ennek ellenére Prokop egri püspök létezésének nagyobb a valószínúsége, mint Koppány egri püspökként való azonosításának. Az első, kétségkívül hiteles, kortárs forrás, mely egy egri püspökre vonatkozik, 1111-ből származik, amikor egy oklevél Wolferus egri püspököt említi, illetve 1113-ban és 1114-ben szintén ugyanő szerepelt egri püspökként. ${ }^{56}$ Ettől kezdve az egri püspökök sora már többé-kevésbé követhető napjainkig.

A régészeti kutatások is azt igazolják, hogy lényegében Kálmán uralkodásától számolhatunk a székesegyház valamint a püspöki palota építésének kezdetével is. A székesegyházat közvetlenül a rotunda északi oldalán kezdték építeni, tájolását is ahhoz igazították. Az új katedrális háromhajós, háromapszisos, keresztház nélküli bazilikának épült (15. kép). Elsőként a nagy méretú kváderkövekből falazott szentélyfejet építették fel. Az apszisok elótti szentélyszakaszokat T vagy kereszt alakú pillérek, és nekik megfelelő lapos, hasáb alakú falpillérek határolták nyugat felól. A mellékszentélyekből csak az apszisok indítása, valamint a szentélynégyzetük maradt ránk. A legépebben a főapszis maradt meg, de ívének nagyobbik, középsó részét ennek is átépítették, vélhetően a tatárjárás pusztításai után. Ennek ellenére északi oldalán megmaradt az eredeti lábazati profil és a belőle induló, függóleges pálcatag, amely függóleges tagolást adott az apszis kváderfalának. ${ }^{57}$

\footnotetext{
SUGÁR 1984, 29.

5 SugÁr 1984, 31-32; GYÖRFFY 1987, 80.

56 SugÁR 1984, 38, 39; GYÖRFFY 1987, 80

7 KozÁK 1974, 134, 4. kép.
}

Az egri székesegyház háromapszisos szentélytípusa az 1060-70-es években jelent meg Magyarországon, majd a 12. század folyamán széles körben elterjedt. Legkorábbi példája az 1064-es túzvész után felépült harmadik pécsi székesegyház szentélye, amely azonban több lényeges vonásában eltér az egri megoldástól: alatta csarnokkripta helyezkedik el, nincsenek kiemelt szentélynégyzetek, és az apszisok külső falsíkjának nincsen függőleges faloszlop-tagolása. Pécsnél valamivel később, az 1070-es évek közepén épültek fel a váci székesegyház ${ }^{58}$ és a garamszentbenedeki apátsági templom ${ }^{59}$ szentélyei. Mindkettőből csak az apszisalapozások, illetve Vácott még annak is csak a részletei maradtak meg, így eredeti tagolásukról, a szentélynégyzetek esetleges létezéséről nincsenek adataink. A következő emlék, a Szent László által 1091-ben alapított somogyvári apátság temploma azonban már sokkal több vonásában feleltethetó meg az egri szentély kialakításának. Az apszisok külső falsíkját itt is függőleges elemek tagolták, bár itt lapos lizénákat találunk. Előttük szentélynégyzeteket alakítottak ki, amit téglalap alaprajzú falpillérek és erőteljes, görög kereszt alakú pillérek határoltak nyugat felól. ${ }^{60} \mathrm{Ez}$ az alaprajzi rendszer Lombardiából származik. Egyik első képviselóje a bizonytalan keltezésú 9-11. századi agliatei Ss. Pietro e Paolo. ${ }^{61}$ A régióban a típus nagyszámú képviselöje épült a 11-12. század folyamán. Mindegyiknél jellemző a szentélyek előtti kiemelt szakasz, amit Egerhez és Somogyvárhoz hasonlóan pillérek és falpillérek határolnak el a bazilikális hosszháztól. A ma is álló lombardiai emlékeknél ez minden esetben a keleti boltozott szentélynégyzetet jelenti, ami elkülönül a boltozatlan hosszháztól. Nincs okunk kételkedni abban, hogy Somogyváron és Egerben is ilyen boltozott felépítménnyel kell ebben a keleti szakaszban számolnunk. Az egri szentély lombardiai párhuzamainak közös jellemzője a fóapszis párkányzatát díszító törpegaléria. Míg ez a 11. századi emlékeknél csak egy félköríves záradékú falfülkékból álló sor, a 12. század elején megjelent a régióban a díszesebb és gazdagabban tagolt, oszlopos változatuk is. E típus egyik legkorábbi példája a paviai San Michele fóapszisa, amelyet az egrihez hasonló karcsú félhengeres pálcákból álló függóleges tagolás is díszít. ${ }^{62}$ Míg a lombardiai 12. századi törpegalériákra jellemző az apszisfal tagolásának bevonása a törpegaléria

\footnotetext{
58 BuZÁs-KovÁCs 2019, 136-141.

59 TAKÁCS 2001, 160-161.

60 BAKAY 2011, 117-186.

61 Casanelli-Piva 2010, I, 83-84.

62 Casanelli-Piva 2010, I, 147-151, 130-131. képek.
} 


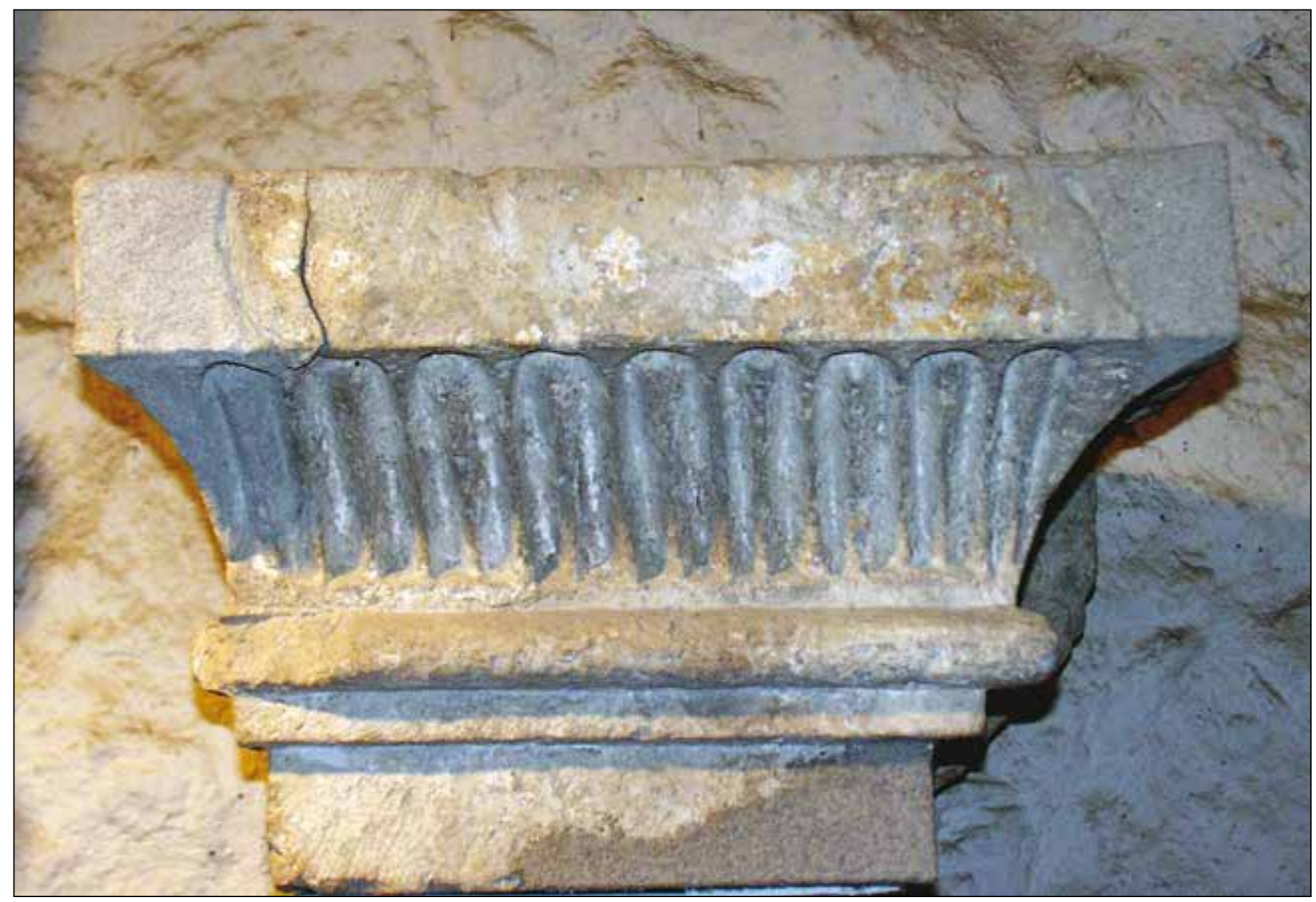

16. kép. 12. század eleji vállkő a székesegyház szentélyéből

Fig. 16. Early 12th century impost block from the cathedral's chancel

szintjébe, addig a velük kronológiailag párhuzamos Rajna-vidéki példák (Speyer, Mainz) esetében az apszisok sokkal eróteljesebb faloszlopos tagolása a törpegaléria alatt, vakárkádokkal lezárul. ${ }^{63}$

$\mathrm{Az}$ egri vár kőtárában több kis méretú, 35-37 cm oldalszélességú fejezethez tartozó, kihajló profilú, román kori vállkő maradt fenn. Mindegyik vállkő egyik oldala falba való befogásra alkalmas, tehát az alattuk álló oszlopok közvetlenül egy falsík előtt álltak. Az egyik vállkövet félköríves záródású, bordákkal tagolt, álló levelek sora díszíti ${ }^{64}$ (16. kép). Ilyen levélábrázolás pontos párhuzamát ismerjük az 1105-1108 körül alapított dömösi prépostság altemplomának egyik oszlopfójéről is. ${ }^{65}$ A vállkövek szerkezeti szerepük és méreteik alapján egy törpegaléria részeit alkották. Ezek alapján az egri főapszist elsősorban a paviai San Michele fóapszisának analógiájaként kell elképzelnünk: függőleges pálcákkal tagolt és oszlopos törpegalériával koronázott külsó homlokzattal.

\footnotetext{
63 WiNTERFELD 1993, 51, 127.

64 KozÁK-SEDLMAYr 1987, 8, 13-4. kép.

65 Gerevich T. 1938, CXII/4. kép.
}

A katedrális hosszháza északi falának alapozásán, a keletről számított harmadik és negyedik támpillér között, a belső falsíkon 2016-ban elválást figyeltünk meg. A keleti falszakasz nagyobb méretú, kváderszerúen megmunkált kőtömbökból rakott alapozására rátakarva épült fel a nyugati falszakasz kisebb, tört kövekból készült alapozása. Az elválást már 1966-ban Kozák Károly is megfigyelte a fal külső oldalán. ${ }^{66} \mathrm{Ez}$ arra vall, hogy az északi falat az első, 12. század eleji fázisban csak a szentélytől idáig alapozták le. A bazilika déli oldalán más a helyzet. Bár a keleti rész kváderes felmenő falai itt is csak a szentélynégyzetig, illetve attól nyugatra csak egy-két kváderhosszig maradtak meg $\mathrm{kb}$. az elsó támpillér vonaláig, az alapozás nagy méretú kváderszerú kövei tovább folytatódnak, de csak a keleti első és a második támpillér közti szakaszban, az alapozás folytatása itt is törtkőből készült. ${ }^{67} \mathrm{~A}$ rövidebb szakaszon megépült déli fal hossza alapján legfeljebb a székesegyház hosszházának első, keleti pillérpárját sorolhatjuk ebbe az építési

66 KoZÁK 1974, 24. kép.

67 KOZÁK 1974, 7. kép. 


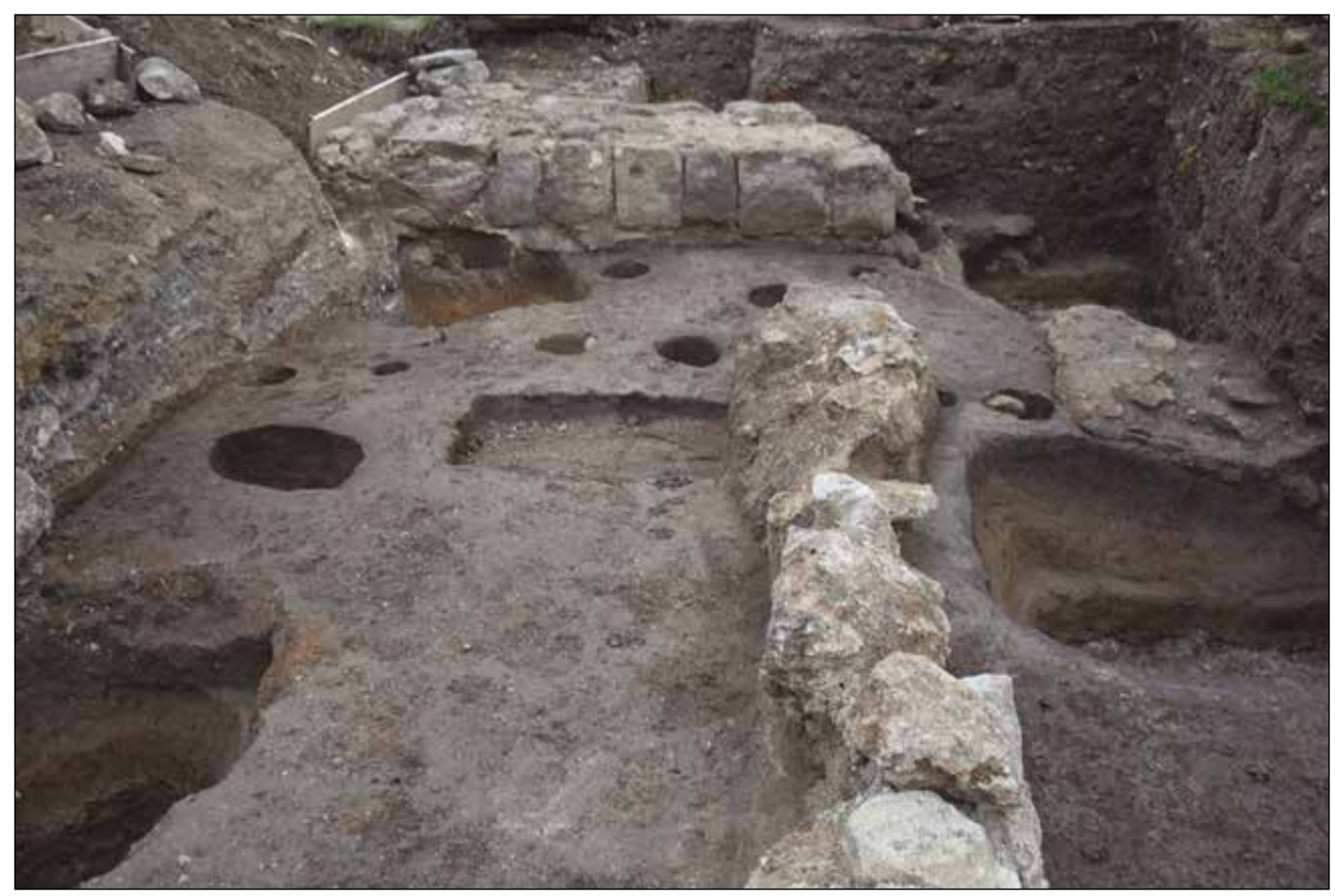

17. kép. A négypilléres épület előtt feltárt fatorony északi és középső cölöplyukai, 2017

Fig. 17. The northern and middle post-holes of the wooden tower excavated in front of the building with four piers

szakaszba. E pillérpár déli tagjának alapozását Kozák Károlynak sikerült is feltárnia. A hosszház ezáltal meghatározott első szakasza mélyebb is a később kialakított, nyugati szakaszoknál.

A székesegyháztól nyugatra álló, négypilléres, emeletes kápolna nyugati homlokzata elé egy $5 \times 6,3$ m-es alapterületú, cölöpszerkezetes, középpilléres faépület készült, amelynek cölöplyukait sikerült feltárnunk (5., 17. képek). A faépület és a mellette álló négypilléres kőépület kronológiai viszonyát bizonyítja, hogy az általunk feltárt EK-i és középső pillér gödre jól láthatóan a kőfal mellé volt beásva. A középpillér cölöplyukának formája kifejezetten követte a kőfal alapozásának szabálytalanságait, úgy hogy az alapozás és a cölöplyukak között még a szúz talaj egy vékony szelete érintetlenül maradt. A cölöplyukakból négyet már Kozák Károly is megtalált és kibontott, mi további hármat tártunk fel. Ezek betöltéséből 12. századi leletanyag - kerámia és pénzérmék került elő. A faépület északi és déli falát alkották cölöpök: az északit három (két nagyobb szélső és egy kisebb középső), déli oldalt csak kettő, ugyanis itt a faépítmény délkeleti sarkát a kápolna lépcsőtornya foglalta el. A lépcsőtorony nyugati homlokzata előtt is elókerült egy nagy mére- tú, téglalap alaprajzú gödör, melynek a sziklaszintig kiásott mélysége megegyezett a többi cölöplyukéval. Ez feltehetően egy nagyobb középső cölöp helye volt. Ez a cölöpszerkezet erősen emlékeztet néhány 12. századi norvég fatemplom szerkezetére (Nore, Uvdal, Høyjord), ${ }^{68}$ ahol a közel négyzetes hajó tetejére épített harangtornyot támasztja alá egy középső oszlop. Az egri faépületre - szerkezetét és méreteit tekintve is leginkább hasonlító norei és uvdali templomok dendrokronológiai datálás alapján az 1160-as évek második felében épültek. Az egri épület szerkezete alapján hasonló formájú lehetett, és talán harangtorony funkciót láthatott el.

A fatoronytól északkeletre szintén előkerült egy a fatoronyéhoz hasonló cölöplyuk, melyet ugyanaz a szemetes, 12. századi kerámiát tartalmazó réteg töltött be, mint a torony cölöplyukait. $\mathrm{Ez}$ a réteg észak felé egy $20 \mathrm{~cm}$ vastag, a földfelszínre épített falig húzódott. Egy ehhez a falhoz hasonló, de $80 \mathrm{~cm}$ vastag másik fal csonkját találtuk meg 4,8 m-re tóle észak felé. A cölöplyukat és a falakat egyaránt elvágta a 12 . század 30-as éveiben ide épült püspöki palota nyugati hom-

68 ANKER 2005, 29-30, 190-215. 


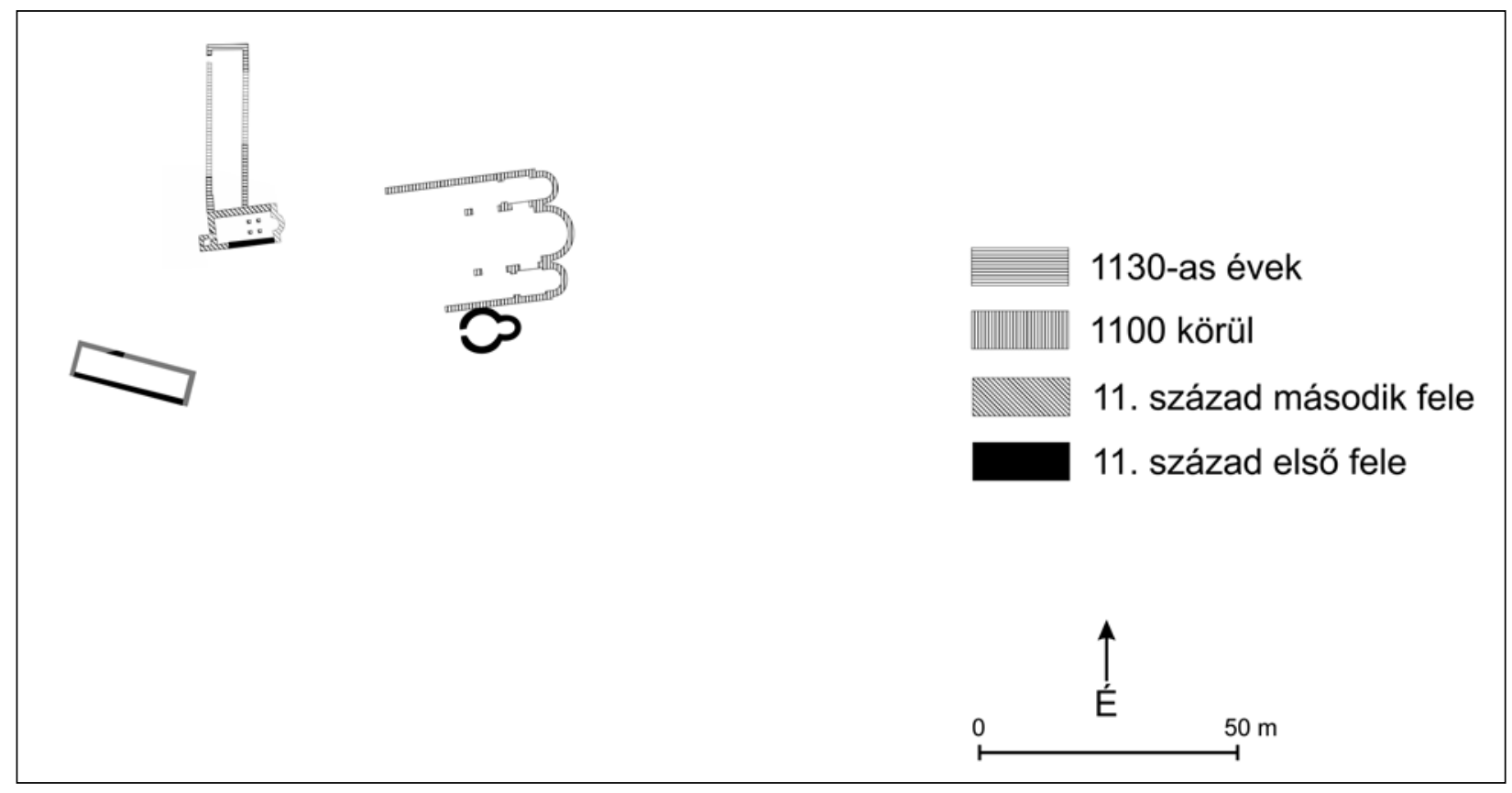

18. kép. Az egri püspöki központ az 1130-as években

Fig. 18. The episcopal seat of Eger in the 1130s

lokzati fala (5. kép). Ez a cölöplyuk, illetve két falcsonk arra utal, hogy a fatoronytól, illetve a négypilléres kőkápolnától északra egy részben kőalapozású faépület állhatott, ám ennek a teljes feltárására egyelőre nem volt módunk. Ez az épület talán az első püspöki palotával azonosítható. Mindenképpen indokolt egy önálló püspöki palota létére gondolunk, ugyanis jó okkal feltételezhetó, hogy a 11. századi királyi udvarházat a 12. században továbbra is - eredeti rendeltetésének megfelelően - az uralkodó használta. A Képes Krónika szerint II. István király (1116-1131) Egerben súlyos betegségbe esett, ${ }^{69}$ ami arra vall, hogy Eger ekkor rendelkezhetett királyi szálláshellyel, ami nagy valószínúséggel a 11. századi eredetú királyi kúria lehetett.

\section{A püspöki központ a 12. században} (18., 19., 22. képek)

A fatorony és a tőle északra álló faépület bontására akkor került sor, mikor az emeletes kápolna északi oldalához egy $32 \mathrm{~m}$ hosszú és $8 \mathrm{~m}$ széles, kváderfalazatú kőépületet emeltek (18. kép). Ezt bizonyítja, hogy a fatorony északkeleti cölöplyukát kitöltő szemetes réteget, illetve a kápolnától északra álló korábbi épület cölöplyukát és kőfalait már vágta a kváderépület nyugati homlokzati fala. A kváderépületet jól keltezi a fatorony északkeleti cölöplyukából 2017-ben előkerült

69 SRH I, 444.
II. István és II. Béla dénár és 11-12. századi kerámia, ${ }^{70}$ valamint a palota északi részén, a nyugati homlokzat előtt, az építési szint alatt talált további II. Béla dénár. Az épület keleti falának déli végét 1975-ben Kozák Károly már feltárta, északi végét és délnyugati sarkát 2017-ben mi találtuk meg (4-5. képek). A nyugati homlokzat északi végén egy ajtó küszöbköve is előkerült. A fal déli vége másodlagosan épült hozzá a négypilléres kápolna északnyugati sarkához.

Nem sokkal ennek az épületnek az elkészültét követően emelhettek tőle északkeletre egy hozzá illeszkedő másik, hasonló kváderépületet (4., 19., 21. képek). Ezt 2017-ben szinte teljes egészében fel tudtuk tárni, kivéve északi falának nagyobb részét, ami az északi várfal feletti védőtető alapozásai miatt hozzáférhetetlen volt. Az épületszárnyat a relatív kronológiai megfigyeléseken kívül egy, a déli fala mellé ásott, faragott kőlappal lefedett sírban talált S-végú hajkarika és II. Béla dénárja keltezte a 12. század második negyedére. A sír közelében - bolygatott helyről - egy Könyves Kálmán dénár is előkerült.

A két fázisban, a 12. század második negyedében készült épületegyüttes építése nagy valószínúséggel Martyrius püspökhöz köthető. Martyrius elődje Beztrius püspök volt, akit azonban csak egy 1135-ös királyi oklevél méltóságsorából ismerünk. ${ }^{71}$ Martyrius 1135-ben még veszprémi püspök volt, de ebben az évben már Péter vette

70 BERECZ 2019, 95-105.

71 SUGÁr 1984. 42. 


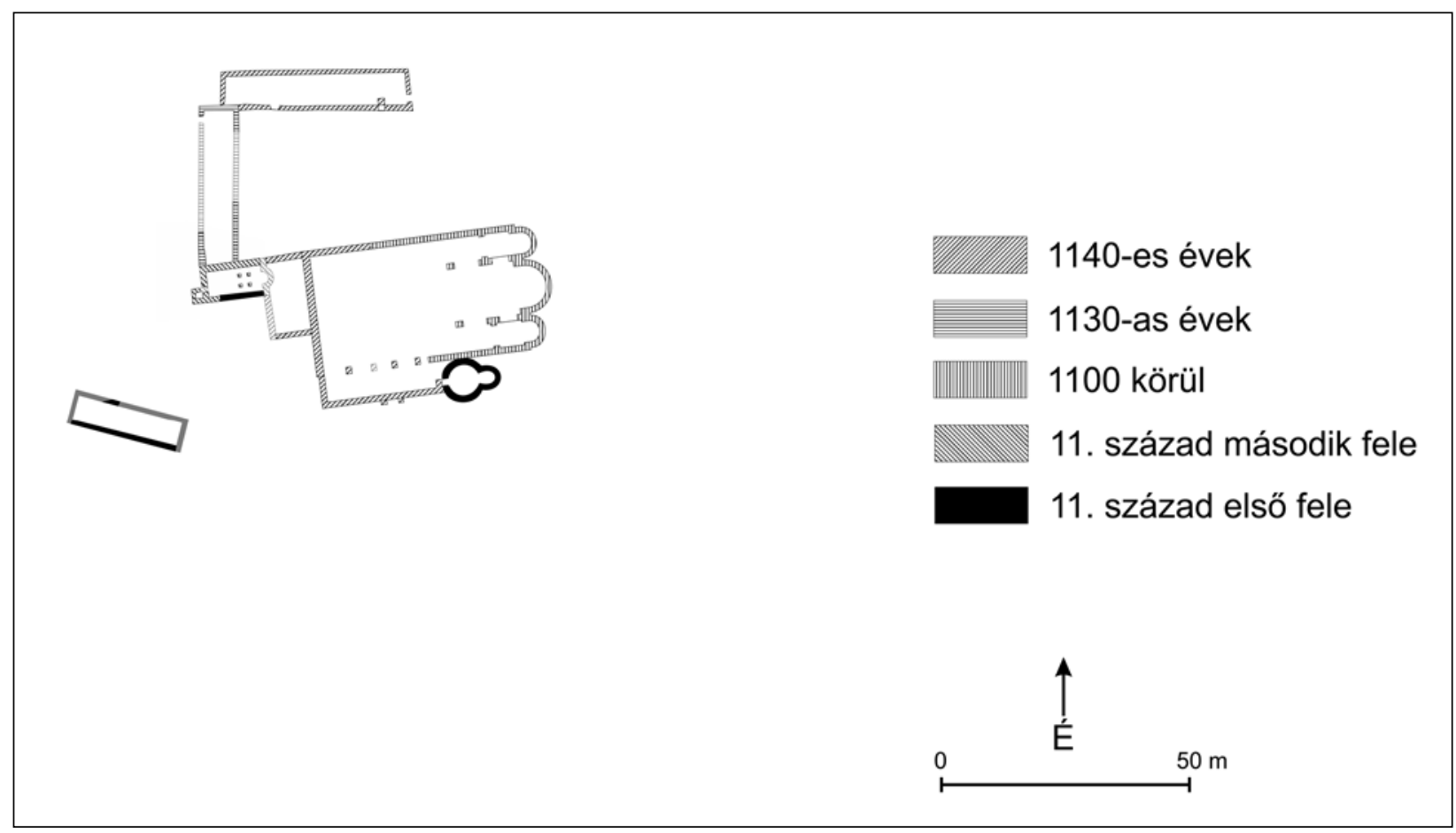

19. kép. Az egri püspöki központ az 1140-es években

Fig. 19. The episcopal seat of Eger in the 1140s

át a veszprémi püspöki méltóságot, így valószínú, hogy Martyrius már akkor átkerült Egerbe, bár egri püspökként az első említése 1142-ből maradt fenn. 1143-ban felszentelte a hernádszéplaki bencés apátság templomát. Egri püspöksége akkor ért véget, amikor 1150-ben vagy 1151-ben megválasztották Esztergomi érsekké. 1150-ben szentelte fel az óbudai Boldogságos Szúz templomát, ${ }^{72}$ majd 1156-ban, már esztergomi érsekként állíttatta fel az esztergomi Szent Adalbert bazilikában a Boldogságos Szúz oltárát, ami a katedrális újjáépítésének lezárását is jelentette. Ez az oltár a székeskáptalan számára készült, a matutinumok és vesperák tartására. Ezzel együtt II. Géza királytól jelentős adományt is kieszközölt a káptalan számára. ${ }^{73}$ Martyrius ezek szerint jelentős építtető volt, és ez egri egyházmegyéjének központjában is tapasztalható lehetett. Úgy tûnik, hogy már egri püspöksége első éveiben, még II. Béla uralkodása alatt megkezdhette egy új püspöki palota építését a régi kisebb és egyszerúbb, részben fából készült palota helyén, a püspöki kápolna északi oldalán. Ezt az épületet azután hamarosan - legkésőbb az 1140-es években - egy új épületszárnnyal egészítette ki, amely minden bizonnyal káptalani épületként értelmezhető.

\footnotetext{
2 RuPp 1868,11

3 SUGÁR 1984, 43-46.
}

A további 12. századi egri munkálatokat már nem tudjuk olyan pontosan keltezni, mint a püspöki palota és a káptalanház Martyrius-féle építkezéseit, csak a feltárt falak relatív kronológiájából következtethetünk korukra. Bizonyosan a 12. században, lehetséges, hogy még Martyrius idején épülhettek fel a székesegyház nyugati részének körítőfalai és déli oldalkápolnája, illetve az a pillérsor is, amely e déli kápolnát a székesegyház hosszházától elválasztotta (19-20. képek). A székesegyház hosszházának déli falán, a második támpillértől nyugatra a keleti falszakasz kváderes alapozásától eltérő törtkő alapozás került elő a külső falsík kutatása során Kozák Károly 1971-es ásatásán. Ezt az alaptömböt nyugat felé a 13. század közepén épült hosszházfal alatt egy sekélyebben elhelyezkedő, nagy méretú kváderekből rakott fal, minden bizonnyal egy kőlapokból öszszeállított sír oldalfala követte, majd egy pillér mélyebb törtkő alapozása következett. A pillértől nyugatra, egy É-D-i tájolású, kólapokból összeállított sír nyúlt be a folytatódó 13. század közepi, kváderes alapfal alá, fölötte pedig egy másik, K-Ny-i tájolású kólapos sír feküdt a 13. század közepén készült fal alapozása alatt. A következő szakaszban, a harmadik támpillértől nyugatabbra a 13. század közepére keltezhető fal alapozásába foglalva egy kisebb méretú kváderekből rakott pillér csonkja került elő. ${ }^{74} \mathrm{~A}$ negyedik

74 KOZÁK 1975, 11. ábra. 

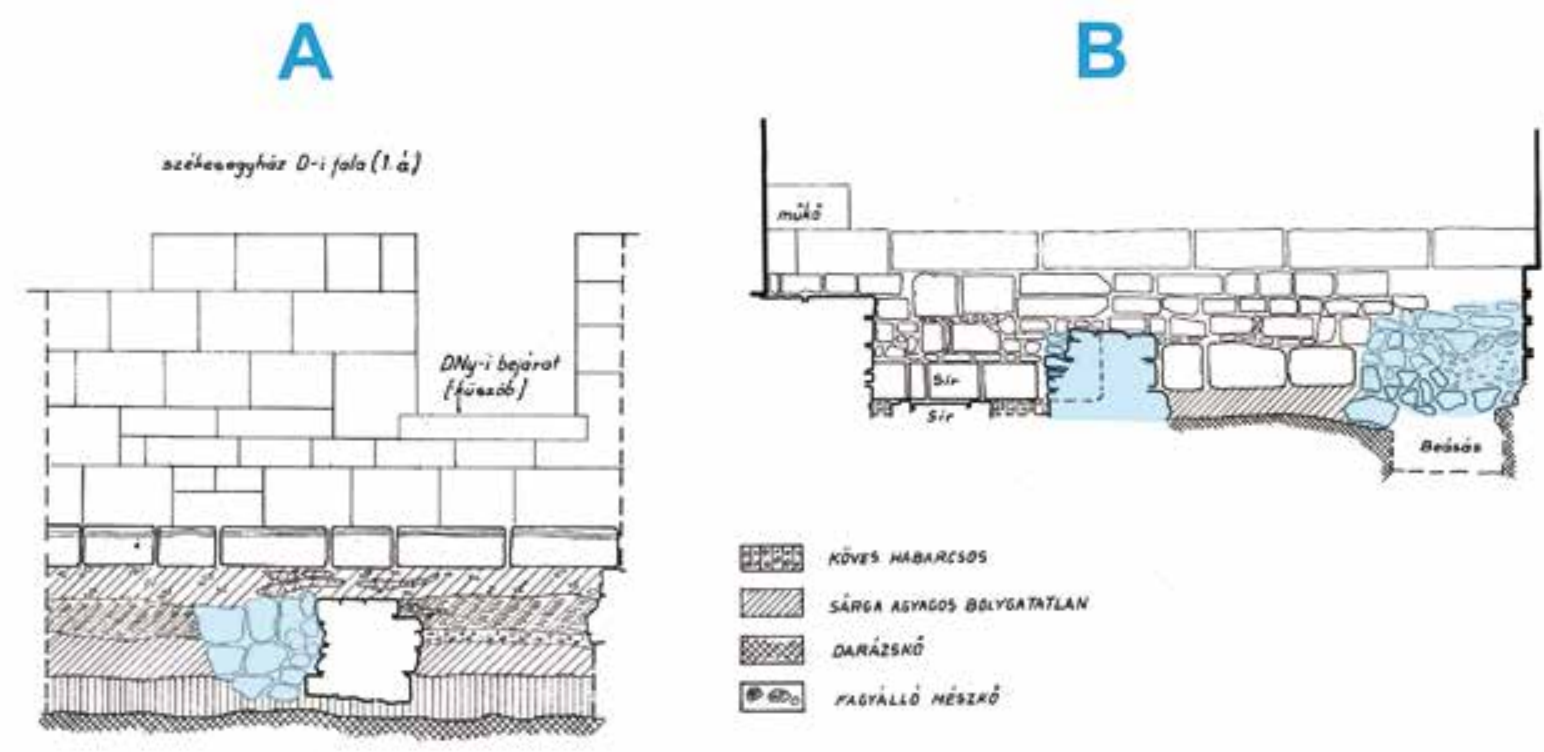

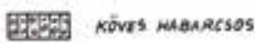

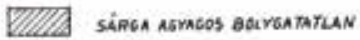

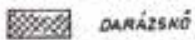

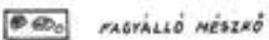
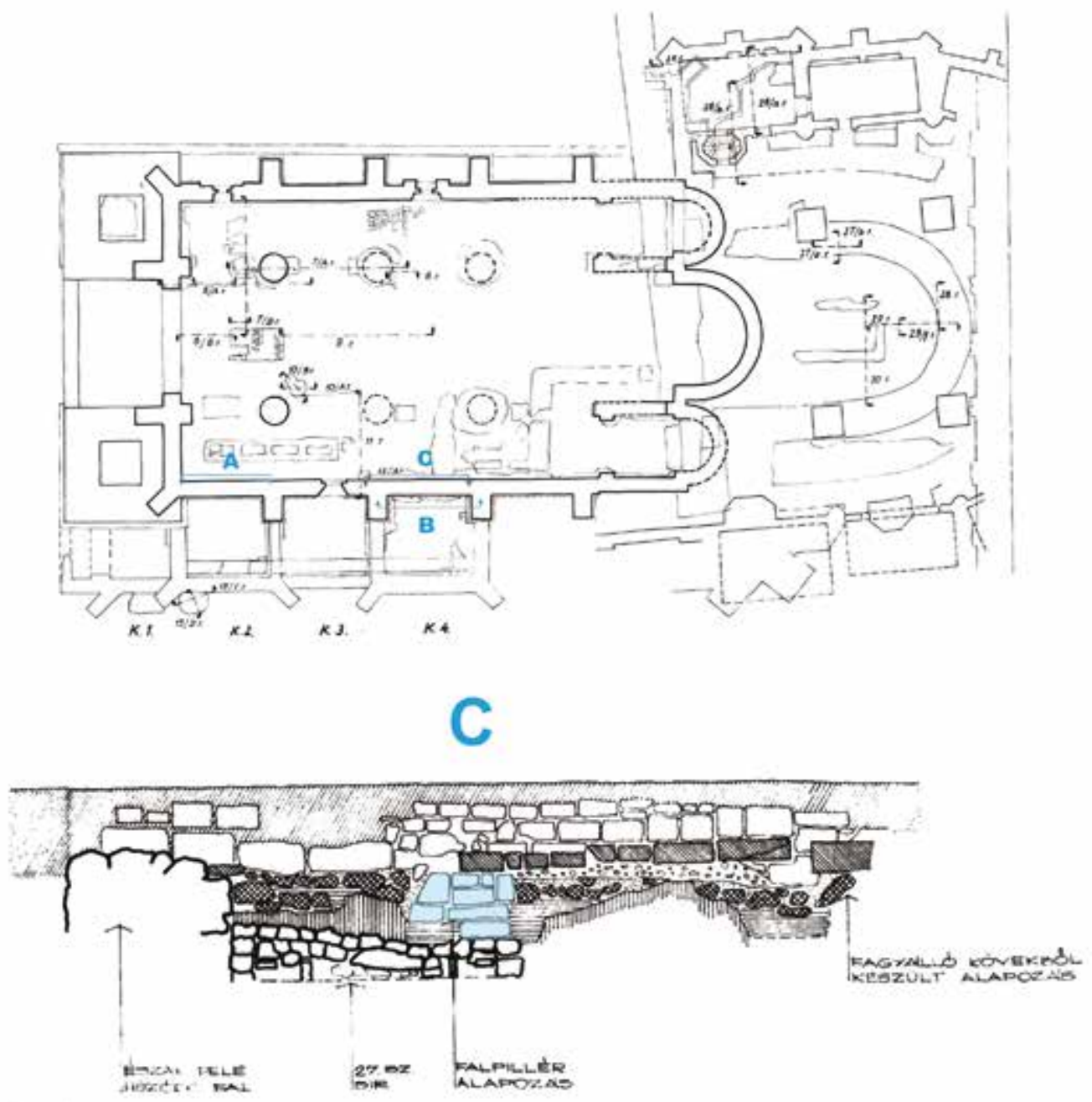

20. kép. A székesegyház déli, gótikus fala alatt feltárt román kori pilléralapozások felmérési rajzai, 1969, 1970, 1971

Fig. 20. Survey drawing of the foundations of the Romanesque piers discovered under the cathedral's southern Gothic wall, 1969, 1970, 1971 


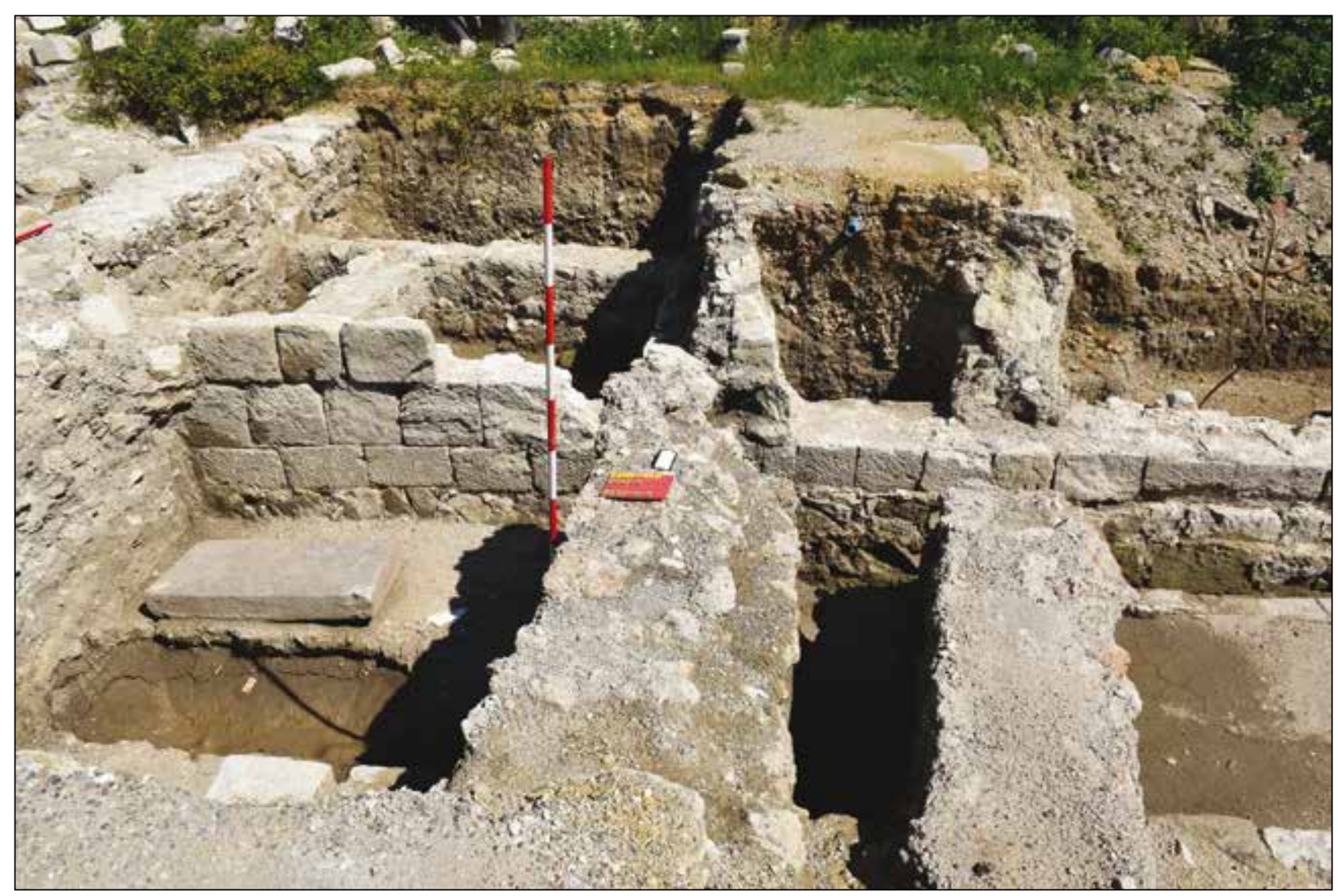

21. kép. A káptalani épület északi szárnyának déli kváderhomlokzata a 2017/3. szelvényben

Fig. 21. The southern ashlar façade of the northern wing of the chapter building in Trench 2017/3

támpillértől nyugatra ugyanilyen helyzetben, a 13. század közepén készült alapozásba foglalva egy törtkő alapozáson egy kis méretú kváderekből rakott hasáb alakú pillér alsó két kvádersorát tárták fel. ${ }^{75} \mathrm{E}$ pontszerúen alapozott román kori pillérek a gótikus székesegyház déli fala alatt kívül és belül egyaránt megfigyelhetők voltak. Kozák Károly feltárásai alapján nyilvánvaló, hogy a román kori bazilika hosszházának déli fala helyén nem tömör fal, hanem külön alapozott, kváderekből rakott hasáb alakú pillérek sora állt. A dokumentált három pilléren kívül - nagyjából egyenletes pillérosztást feltételezve - még egy pillér létét feltételezhetjük a keletról számított negyedik támpillértől keletre. E pillérek törtkő alapozása a bazilika északi fala nyugati felének alapozásával rokon, így feltehetóen már a bazilika hosszházának második építési szakaszában készülhettek. A déli fal alatt feltárt pillérektől délre már Pataki Vidor talált egy román kori, $\mathrm{K}-\mathrm{Ny}-\mathrm{i}$ irányú falat a déli gótikus kápolnasor alatt. E falat teljes egészében Kozák Károly tárta fel. Jobbára csak a fal törtkő alapozása került elő, a felmenő fal kvádereiból már kevés maradt meg.
A fal a rotundától nyugatra indul. Keleti vége derékszögben észak felé befordulva falpillért képezett. E pillér keleti falsíkja enyhén íves volt, ami arra vall, hogy eredetileg a rotunda nyugati falához épült hozzá utólag. A K-Ny-i irányú déli fal középső szakasza előtt, annak déli oldalán két alapozástömb került elő, amely közül a keletin egy in situ román kori ión oszloplábazatot találtak. Ezeket a maradványokat egy déli kapu maradványaiként azonosították. Az oszloplábazat szintje a román kori székesegyház járószintjénél mélyebben, a rotunda járószintjének magasságában helyezkedett el. A déli fal a román kori székesegyház nyugati falának vonalában, derékszögben észak felé fordult. Itt a gótikus kápolnafal alatt Kozák Károly a román kori fal külső síkjának felmenő szakaszából is fel tudott tárni három sor kvádert. ${ }^{76} \mathrm{~A}$ feltárt falak egy olyan oldalkápolnát alkotnak, amely a székesegyház nyugati felével egyszerre épült, terét a székesegyház felé pillérsoros árkád nyitotta meg, keleti vége pedig a 11 . századi rotundához csatlakozott, azzal valószínúleg egybenyílott. A kápolna oszlopos keretezésú kapuja a déli oldalon 


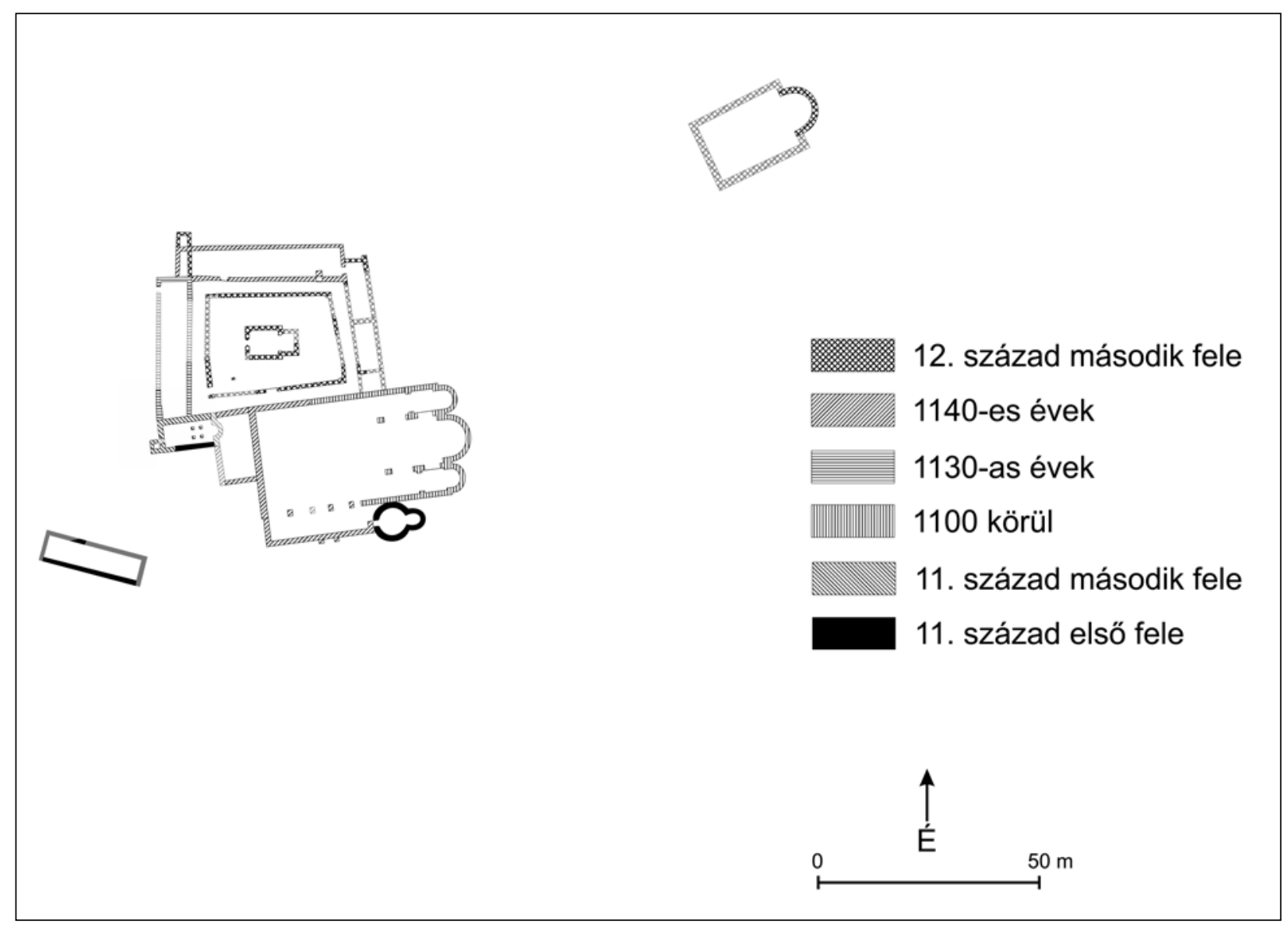

22. kép. Az egri püspöki központ a 12. század második felében

Fig. 22. The episcopal seat of Eger in the later 12th century

helyezkedett el. A kápolna - a rotundával együtt - a tatárjárás idején pusztulhatott el, majd az ezt követő újjáépítés során romjait elbontották, helyére a gótikus hosszház déli fala és támpillérei épültek. Csak a 15. század első felében, Rozgonyi Péter püspök emelt a helyén két kápolnát. Ezek a Boldogságos Szúznek szentelt prépostság kápolnájával és a püspök saját temetkezési helyének szánt Szent Mihály kápolnával azonosíthatók. ${ }^{77}$ Rozgonyi Péter 1430 . július 13-án arra hivatkozva alapította meg a Boldogságos Szúz prépostságot, hogy azt már Szent István király létrehozta, de időközben a tatárok elpusztították. ${ }^{78}$ A prépostság Szent István-i alapításának hagyománya feltehetóen a román kori székesegyház déli oldalkápolnájának szentélyét alkotó Szent István kori rotunda alapításából eredt.

Valószínúleg már a 12. század második felében, a káptalani épület északnyugati sarkához egy kis méretú, négyszögletes tornyot toldottak, előtte pedig egy keskeny helyiséget választottak le az épület nyugati végéből (22. kép). Ezek falai

77 DÉTSY 1964, 1, 9.

78 SUGÁr 1984, 150. 2016-2017-ben kerültek elő (4. kép). A torony északi homlokzata elé lezuhanva került elő egy szvasztikával kombinált kereszttel díszített kváder (23. kép). Ugyancsak a század második felében épülhetett fel a káptalani épület keleti végéhez utólag hozzátoldott keleti épületszárny, ami a két korábbi épületszárnnyal és a székesegyházzal együtt egy négyzetes udvart zárt körül. Az épület keleti szárnyának északi végét a múzeum kőtárának építésekor, 1969-ben, Kozák Károly tárta fel, ${ }^{79}$ déli végét pedig 2016-ban nekünk sikerült megfogni (3. kép). Ezen a részen egy válaszfal csonkjai is előkerültek, bár a 2000-es években lefektetett csatornák és kábelek árkai csaknem teljesen elpusztították a maradványait. A válaszfal a szárny déli helyiségét, feltehetően a katedrális sekrestyéjét választotta le a szárny többi részétől. A keleti szárnyból csak a törtkő alapozásokat ismerjük. Az épületek által keretezett udvaron egy kerengó is épült. A székesegyház északi homlokzata mentén 1966-ban és 1969ben Kozák Károly egy kelet-nyugati irányú falat

79 KÁRPÁtI 2010, 173-174 


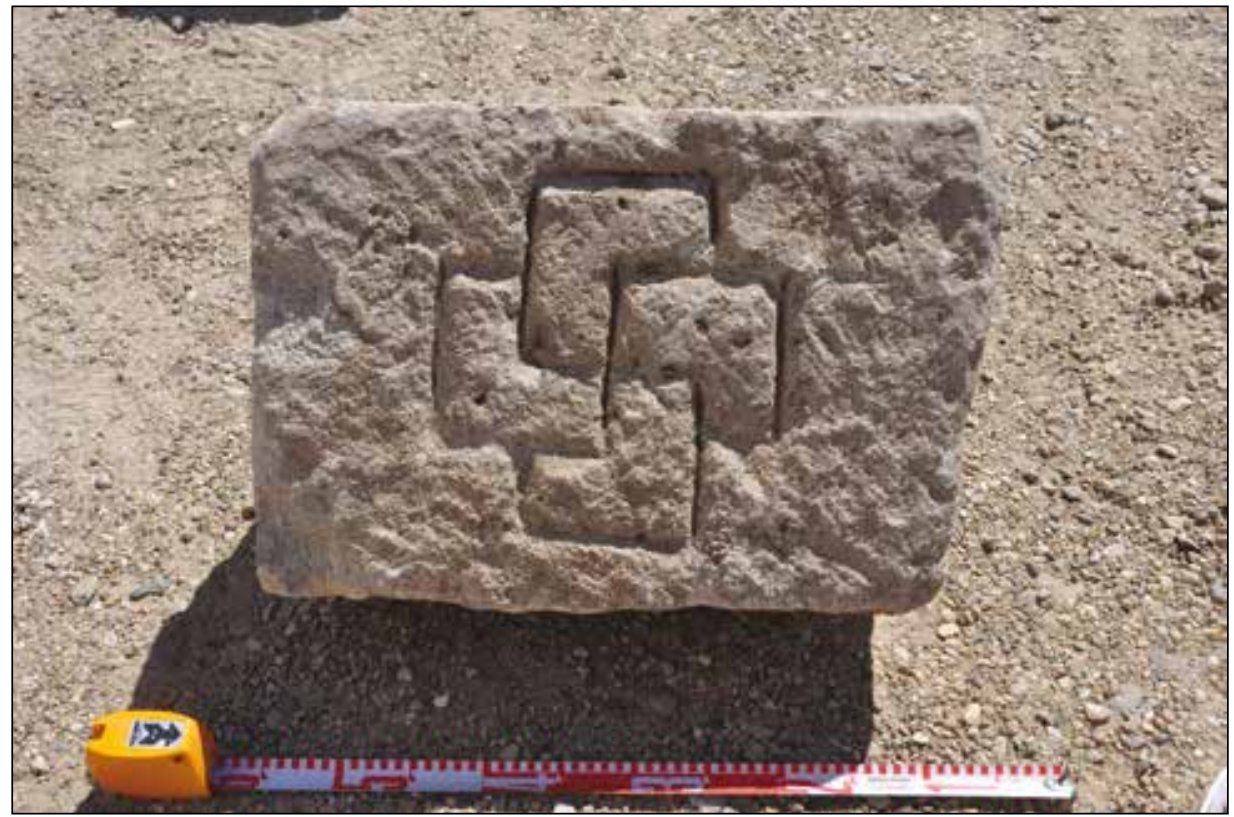

23. kép. 2016-ban előkerült szvasztika-kereszttel díszített kváderkő a káptalani épületegyüttes északnyugati sarkán álló kis torony omladékrétegéből

Fig. 23. Ashlar decorated with a swastika cross found in 2016 in the debris of the small tower standing at the north-western corner of the chapter building complex in 2016

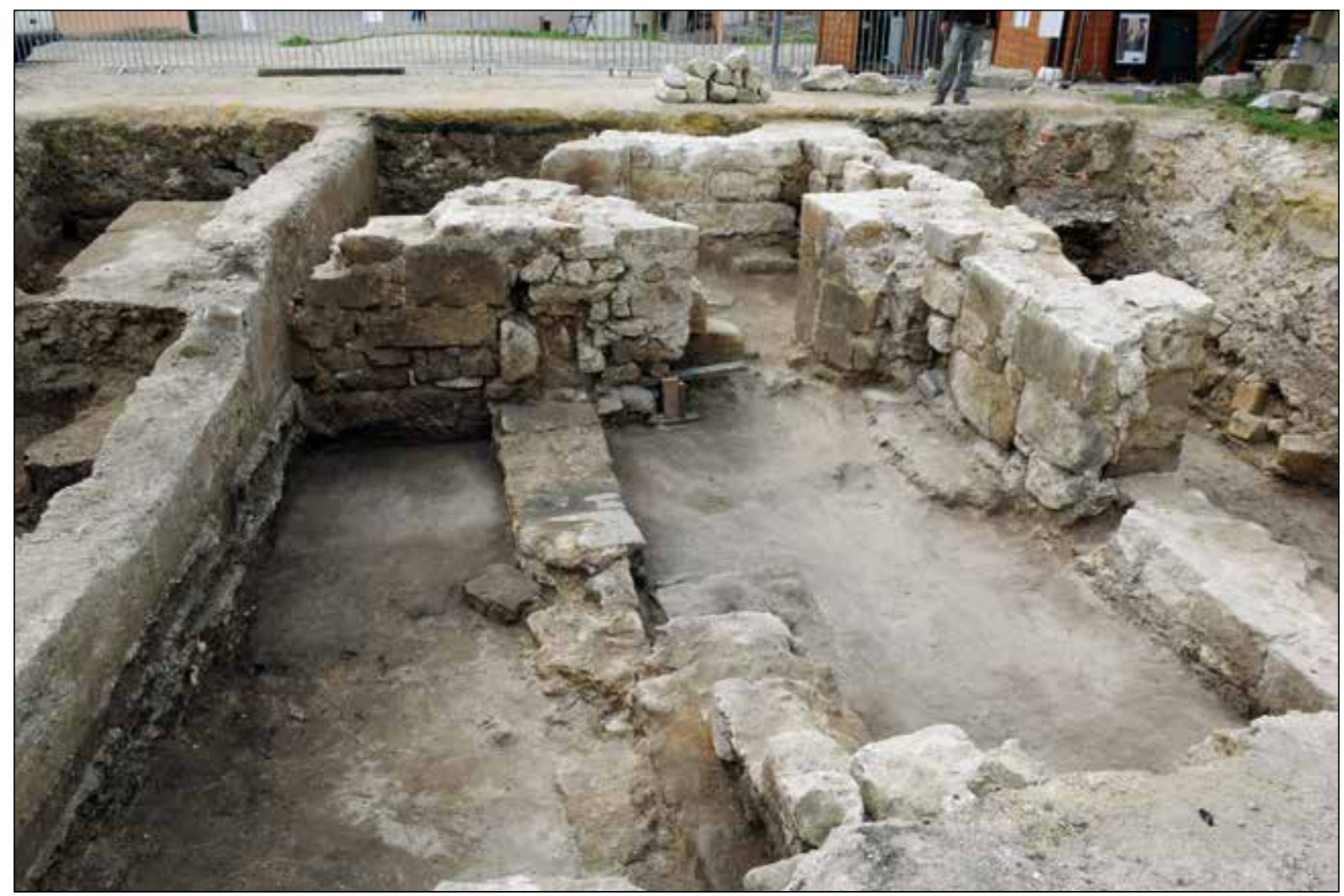

24. kép. A káptalani kerengő északi szárnyának falmaradványa a 2017/4 szelvényben

Fig. 24. Remnants of the wall remains of the northern wing of the cathedral's cloister in Trench 2017/4 
talált, ám ennek korát és funkcióját nem vizsgálta. ${ }^{80}$ 2016-ban végzett ásatásunk során kiderült, hogy ez a Kozák Károly által már megtalált, $65 \mathrm{~cm}$ széles, kváderkövekból épült fal a kerengó déli fala. A kerengő keleti falának déli befordulását 2016-ban megtaláltuk (3. kép), és vele szemben 2017-ben meg tudtuk figyelni a kerengó északkeleti falsarkát is, valamint az északnyugati falsarkát is, melyet egy török kori gödör erősen megrongált (4. kép). A nyugati szárny déli szakaszát Kozák Károly már 1975-ben feltárta. A kerengó járószintje magasabban helyezkedett el a káptalani épület északi szárnyának építési szintjénél. Erről a magasabb szintről vezetett le egy lépcső az északi szárny keleti részébe a kerengőból. A lépcsőre nyíló ajtó kerete már nem maradt meg, de az épület déli falán a kerengő járószintje alatti alsó kvádersor még megvan az ajtó helyén, ezért az ajtót csak utólag, a kerengő építése során nyithatták a korábbi falba. A kerengőfal szerkezete is rekonstruálható. A $60 \mathrm{~cm}$ vastag, kváderekből épült térdfal több szakaszon fennmaradt (24. kép). A kőtári anyagból ismert egy olyan $42,5 \mathrm{~cm}$ vastag ikeroszlop lábazat, amely e térdfalon állhatott. Mivel az oszloplábazat vastagsága nem éri el a térdfal vastagságát, feltehetően pillérek szakaszolták a kerengőnyílásokat. A 2017-es ásatáson, újkori másodlagos befalazásokból előkerült két kis méretú boltívhez tartozó, profilálatlan, faragott kőelem, 2016-ban pedig egy ívek közé illeszkedő, háromszögú kvádert találtunk itt. Ezekből rekonstruálható a kerengőnyílások ívezete és a felettük emelkedő kváderfal. A kerengő déli és keleti szárnya 2-2,5 m széles volt, és benne számos kólapokból összeállított Árpád-kori sír helyezkedett el. Egy ilyen sír maradványait a kerengőfal udvar felőli oldalán is megtaláltuk, de a 2000-es években kiásott dréncső árka ennek nagy részét elpusztította. Ez az árok semmisítette meg a kerengő délnyugati sarkát is. Az északi kerengófolyosóban talált, fentebb már említett II. Béla pénzzel keltezett sírban is két temetkezés volt, a sírt egy faragott, de díszítetlen kőlap fedte. Tóle keletre egy téglafalazatú, kőhasábokkal fedett sírban szintén több temetkezést lehetett megfigyelni.

A székesegyház nyugati homlokzatának északi fele előtt, az emeletes püspöki kápolna és a katedrális homlokzata között egy elő́csarnokot építettek, amely a székesegyház és a káptalani kerengő főbejárataként szolgálhatott. Az előcsarnoknak a déli és az északi fala került elő Kozák

80 KozÁK 1974, 142, 24-29. képek.
Károly és Nagy László ásatásai során (9. kép). Nyugati fala a 14. századi előcsarnok nyugati falának vonalába esett, ezért a 14. században elbontották.

A kerengőudvar közepén egyenes szentélyzáródású kápolnát emeltek, melynek falait 193738-ban, majd 1984-ben tárták fel (22. kép). Fennmaradt a kápolna nyugati kapujának és északnyugati sarok-faloszlopának lábazata is. A székesegyházi kerengő udvarára épült kápolna esetére a legjobb analógia a regensburgi székesegyház kerengőjének az udvarára épült Mindenszentek kápolna. Ezt II. Hartwig regensburgi püspök (1155-1164) emeltette saját sírkápolnájaként. ${ }^{81} \mathrm{Az}$ egri kápolnát, amelyet később gótikus stílusban újjáépítettek, a Szent István templommal azonosíthatjuk. Lokalizálását az 1508-as leltár teszi lehetővé, amely a vár fakapuját a Szent István templom mellett említi, ${ }^{82}$ ez a fakapu pedig a székesegyháztól északra nyílhatott a várfalon. A templom titulusa Szent István király volt. ${ }^{83}$

Mikor Martyrius 1151-ben esztergomi érsek lett, az egri egyházmegyében egy nem kevésbé jelentős személyiség, a párizsi egyetemen tanult Lukács püspök (1151-1158) követte őt, aki Martyrius érsek halála után szintén elnyerte az esztergomi érseki széket. ${ }^{84}$ Később, már a század utolsó negyedében Péter került az egri püspöki székbe (kimutatható 1181-1197 között), aki III. Béla diplomatájaként is múködött. Az ó korában keletkezett a magyar püspökségek tizedjövedelméról az a kimutatás, amely szerint Esztergom után a második leggazdagabb egyházmegye az egri volt, évi 3000 márka jövedelemmel. ${ }^{85}$ A püspökség gazdagsága az e korban zajló nagyléptékú egri építkezésekben is megnyilvánult. Talán Péter püspök alapíthatta a 12. század utolsó két évtizedében a Szent Péter egyházat is, amelyet először csak az 1332-1337 között készült pápai tizedjegyzék említ, 1350-ben és 1358-ban pedig Eger-elóhegyi Szent Péter templomnak nevezik. Mellé 1430-ban Rozgonyi Péter püspök alapított társaskáptalant. Helyét a székesegyháztól keletre, a késóbbi külsôvár területén kereshetjük: talán apszisából alakították ki az 1530-as években a Csaby-bástyát, amelynek falait véglegesen a 18. század eleji keleti várárok kiásásakor bonthatták el. Területe ma a váron kívülre, a Bástya utca helyére lokalizálható (2., 22. képek).

\footnotetext{
81 TRAEger 1980.

82 DÉTSY-KOZÁK 1972, 146.

83 NAGY G. B. 2004, 173.

84 SUGÁr 1984, 47-51.

85 SUGÁr 1984, 56-58.
} 

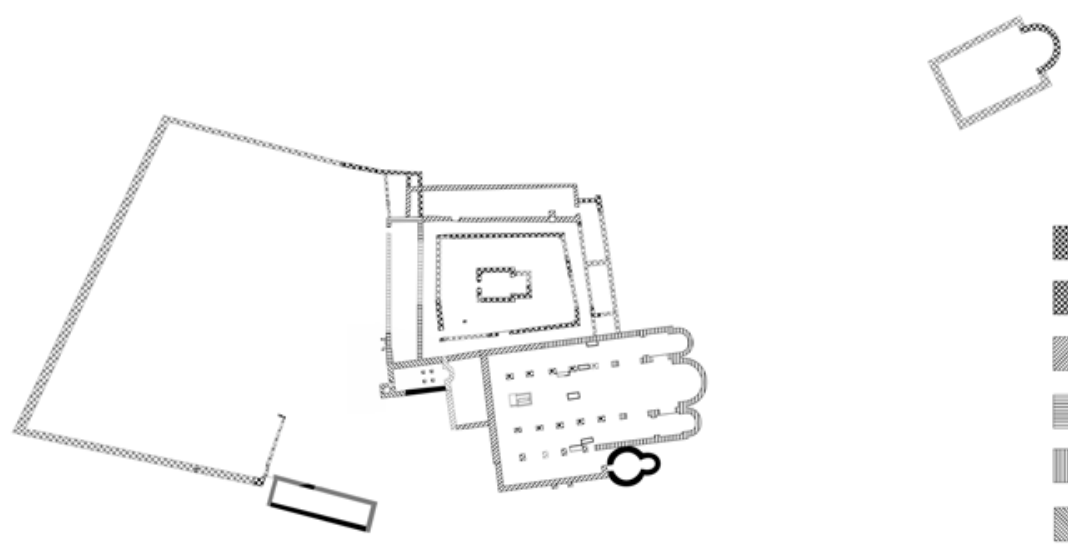

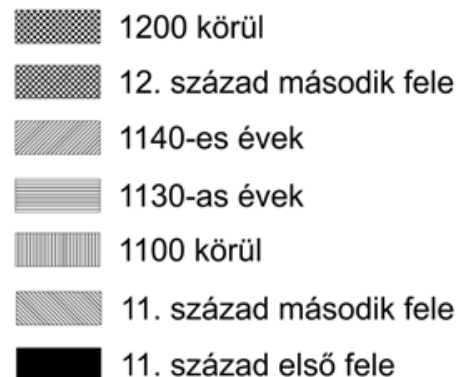

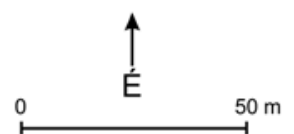

25. kép. Az egri püspöki központ a 13. század elején

Fig. 25. The episcopal seat in Eger in the early 13th century

A püspöki központ a 13. század első felében (25., 29. képek)

A 13. század első felében az egri püspökök jelentős kormányzati szerepet láttak el. Ebben az időszakban Eger élén három kancellári tisztet viselő, így nagy politikai befolyással bíró fópap követte egymást. Katapán még székesfehérvári prépostként III. Béla, majd Imre király kancellárja volt, és kancellárként nyerte el 1198-ban az egri püspökséget is. Ô volt az, aki 1204-ben Imre királyt eltemette Egerben, majd 1217-ben egri püspökként hunyt el. ${ }^{86}$ Utóda Tamás 1209-től szintén kancellárként és székesfehérvári prépostként emelkedett fel II. András király udvarában, 1210-től elnyerte a veszprémi, majd 1212-tól a szebeni préposti címet is, majd Katapán püspök halála után az egri püspöki méltóságot is. Még ebben az évben útra kelt a királlyal a Szentföldre, a keresztes hadjárat résztvevójeként, és onnan csak 1219ben indult, majd 1220-ban érkezett haza. Az egri püspökség élén addig állt, míg 1224-ben el nem nyerte az 1223 novemberében megüresedett esztergomi érseki széket, melyet ugyanezen év végén bekövetkezett haláláig töltött be. ${ }^{87}$ Utóda Kilit püspök már 1219-ben viselte a kancellári és egri préposti tiszteket, majd Tamás esztergomi érseki kinevezése után egri püspökké választották, mely tisztséget 1245 végén bekövetkezett haláláig töltötte be. ${ }^{88} \mathrm{E}$ három főpaphoz köthető Egerben a román kori székesegyház épületének befejezése, és a székesegyház körüli püspökvár kiépítése.

A székesegyház hosszháza oldalfalainak befejezését követóen fejezhették be a belső teret alkotó pillérsorokat. A pilléralapok közül Kozák Károly ásatásai tíznek a maradványait hozták felszínre, mindössze az északi pillérsor két keleti pillére nem került elő. Ezek alapján rekonstruálható a hosszház hat-hat pillérből álló két pillérsorának kiosztása. Az egri székesegyház kőanyagában egy igen jelentős csoportot képviselnek a 13. század elejére keltezhetô kora gótikus faragványok. Ezek nagy része a székesegyház pilléreihez, boltozataihoz és szentélyrekesztőjéhez köthető. A kőtárban található kora gótikus pillér-rétegkövek görögkereszt alaprajzú pillérmagokból, a keresztszárak közé helyezett kisebb, illetve a keresztszárak végébe illesztett nagyobb háromnegyed oszlopokból álló pillérekhez tartoztak. Elófordulnak olyan elemek is, ahol a keresztszárak végéról elmaradt a nagyobb oszlop. Ezek alapján elméletileg két- vagy háromféle pillérforma is rekonstruálható: egy erősebb, minden 
irányban egyformán tagolt, egy gyengébb, ahol legalább az egyik oldalon elmaradtak a nagyobb háromnegyed oszlop tagozatok, illetve egy még gyengébb, ahol két átellenes oldalról is elmaradtak a háromnegyed oszlopok. A feltárt alapozások közül az északnyugatin a pillér bázisának két köve is fennmaradt. Ezek egy $1 \mathrm{~m}$ széles bázisméretet adnak ki. A faragott kövekből rekonstruálható legerősebbik pillér törzsszélessége $110 \mathrm{~cm}$, a közepesé $90 \mathrm{~cm}$, és amennyiben a pillér mellékhajó felé nézó oldalán sem volt nagy háromnegyed oszlop, akkor a törzsszélesség csupán 75 $\mathrm{cm}$ lehetett. Mivel nem ismert a pillérek lábazati profilja, így biztosan csak annyi állítható, hogy a legerősebb, teljesen szimmetrikus pillérforma nem fér rá a feltárt bázisra (26. kép). Ez azért lényeges, mert ezzel kizárható, hogy a gyengébb pillérekról azért hiányzik a fóhajó felé néző tagozat, mert azok a kanonoki kórusban álltak volna, és a stallumok elhelyezése miatt ezt a tagozatot magasabbról, konzolról indíthatták, hiszen a feltárt gyengébb pillérhez tartozó bázis a legnyugatabbra álló pillérpár része, tehát biztosan nem tartozhatott a kanonoki kórus területéhez. A pillérosztás ezek szerint vagy csupa olyan pillérből állt, amelynek nem volt a fóhajó felé néző háromnegyed oszlop tagozata, vagy támváltással kell számolnunk.

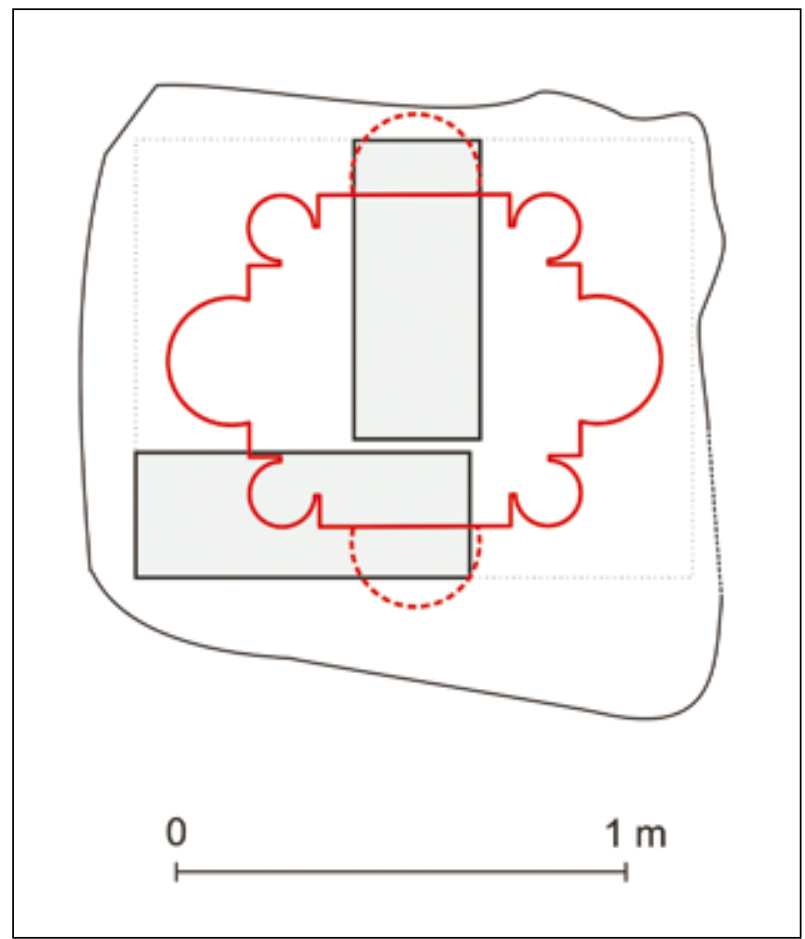

26. kép. A székesegyház hosszházának északkeleti első pilléralapozása és talplemeze a késő román pillérek profiljával

Fig. 26. Foundation and bearning plate of the first northeastern pier in the cathedral's nave, with the outline of late Romanesque piers

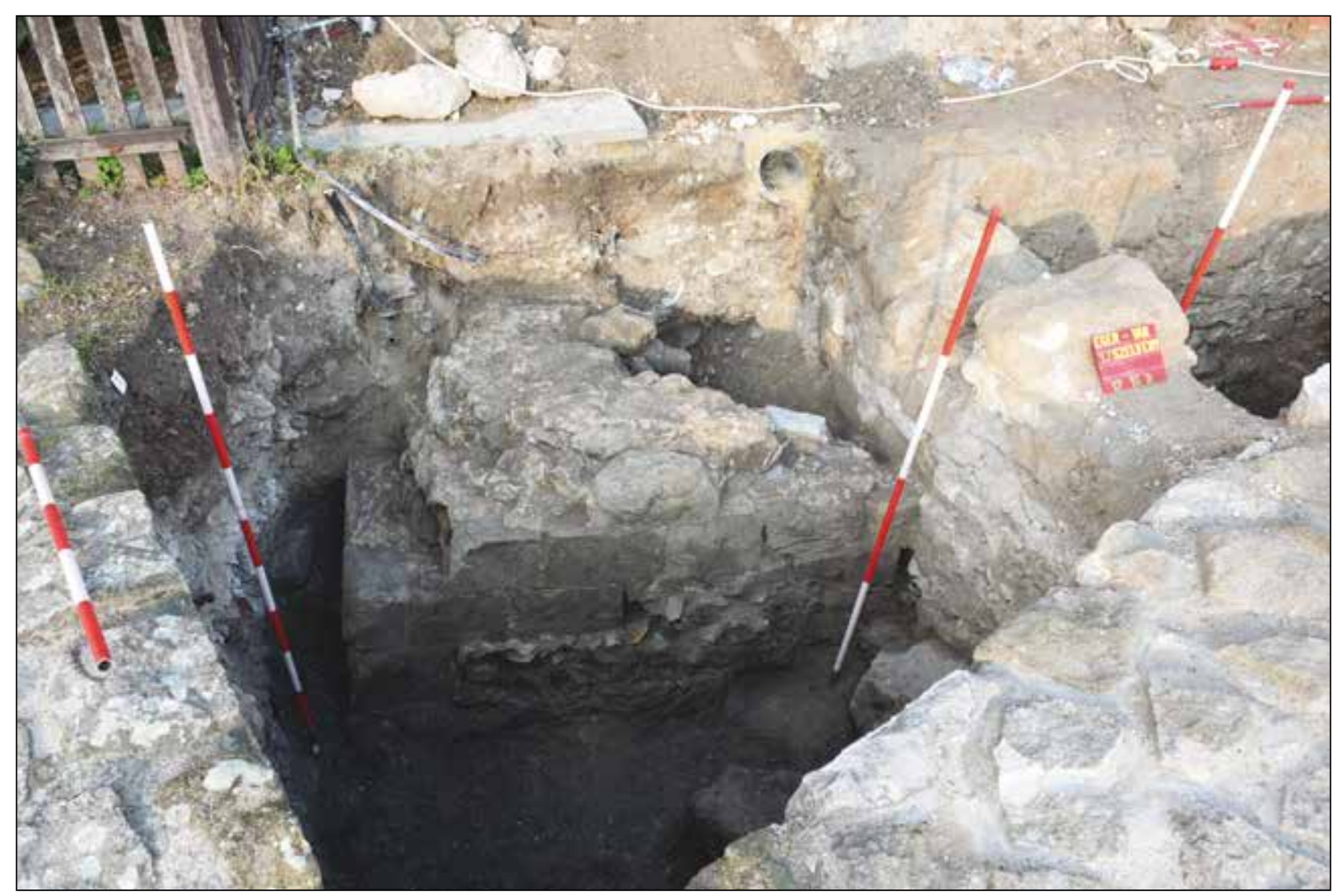

27. kép. A palota körítőfalának délkeleti sarka a 2017/17. szelvényben

Fig. 27. South-eastern corner of the wall enclosing the palace in Trench 2017/17 


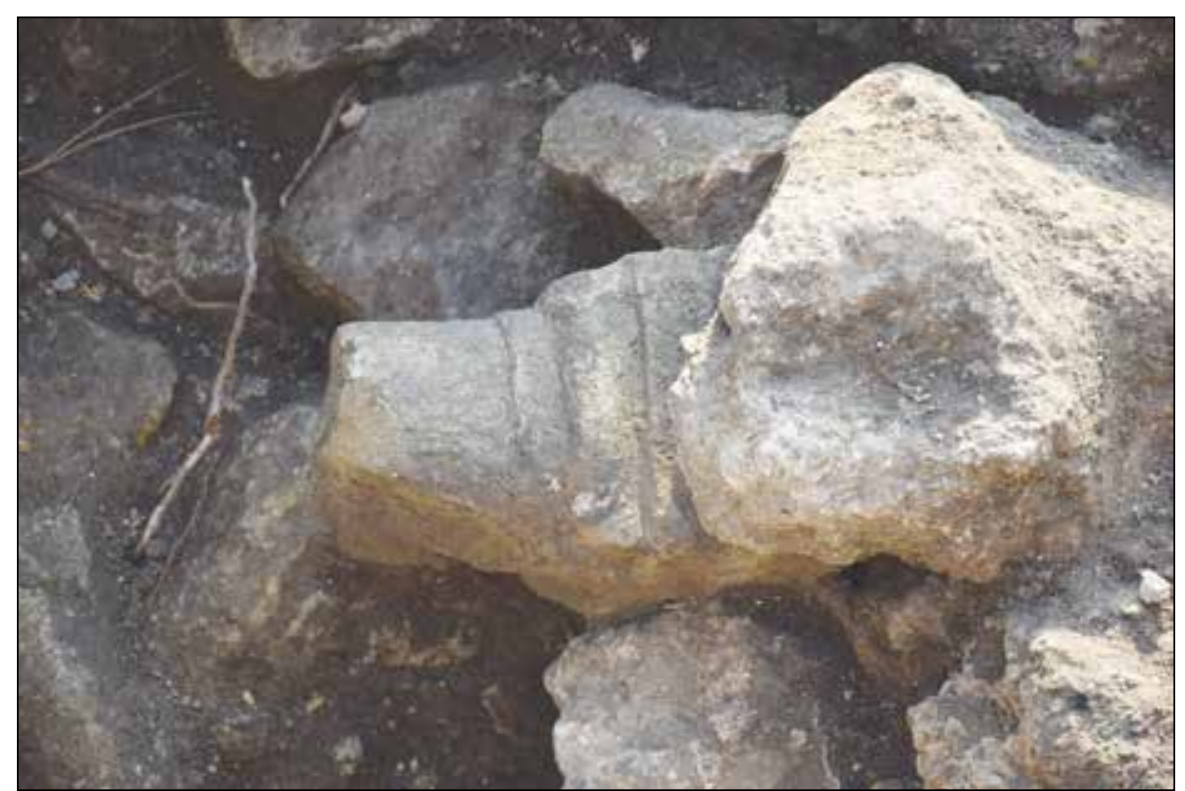

28. kép. Kis méretú román kori oszlop a palota körítőfalának falmagjába falazva a 2017/17. szelvényben

Fig. 28. Small Romanesque column walled into the core of the wall enclosing the palace in Trench 2017/17

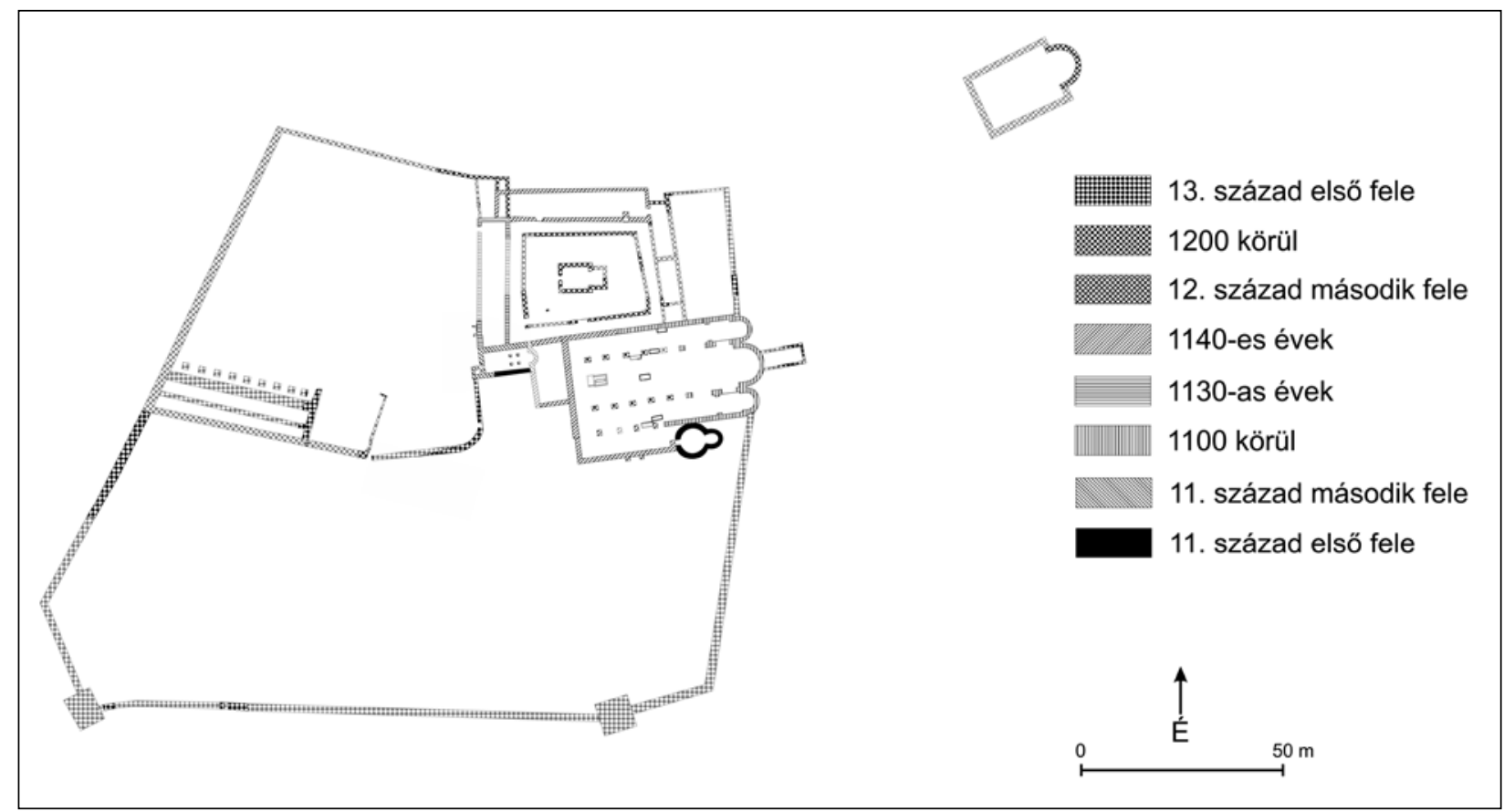

29. kép. Az egri püspöki központ a tatárjárás előtt

Fig. 29. The episcopal seat in Eger before the Mongolian invasion

A főhajó nyugati felében, a második és a harmadik pillértengely között egy sírkamra került elő 1937-ben. A sírkamra egy boltozott, kváderfalú építmény, nyugat felől levezető lépcsővel, és a padlójába mélyített, kőlapokból összeállított sírral. A sírépítmény központi helyzete a székesegyház 12. század második felében épült részében, és egyedi formája alátámasztja azt a fel- tételezést, hogy azonosítható lehet Imre király sírjával. ${ }^{89}$

A hosszház keleti pillérpárja és a szentélynégyzet $\mathrm{T}$ alakú pillérei között nagyobb a távolság, mint ami a többi rekonstruálható pillérállás között adódik, ami a szentélyek előtt egy hang-

89 Havasi 2017; BuZÁs-Kovács 2019, 224-229. 
súlyos térszakasz létét feltételezi. Ennek a keresztházra emlékeztető szakasznak a nyugati oldalán számolhatunk a kanonoki kórus szentélyrekesztőjével. A rekesztőfal fontos elemeit már Sedlmayr János is azonosította, sőt a falat tagoló félköríves fülkesor egy részét rekonstruálta is a vármúzeum régi kőtárában. Az általa összeállított vörös tufából faragott szerkezetekhez tartozó, azonos tagolású fehérmárvány fülkék töredékeit nagyrészt Kozák Károly találta meg, ám lelőhelyük ismeretlen volt. E töredékeket Havasi Krisztina publikálta. ${ }^{90} \mathrm{~A}$ káptalani kolostor északnyugati sarka előtt húzódó árok betöltéséből 2017-ben nagyszámú további fehérmárvány töredéket találtunk, többek között két ornamentális darabot: egy indadíszes párkánytöredéket (31. kép) és egy ívháromszöget díszítő faragványt madáralakkal és szőlőfürttel (30. kép). Mivel ezen a helyszínen már Kozák Károly is végzett feltárást 1981-ben, ${ }^{91}$ valószínű, hogy a többi fehérmárvány töredéket, vagy legalábbis azok egy részét ő is itt találhatta meg. Ez az árok a káptalani kolostort vehette körül. A tatárjárás után betöltött északnyugati vége a kolostor sarkánál derékszögben észak felé fordult és kiszélesedett, feltehetően a benne összegyúlt esővíz kivezetése érdekében.

2017-ben a székesegyháztól nyugatra egy nagy kiterjedésú falrendszer nyomaira bukkantunk (25. kép). Ennek északkeleti része a késóbbi gótikus püspöki palota keleti végének középtengelyében került elő (4. kép). Itt a káptalani kolostor északnyugati sarkához épült kis torony nyugati oldalára egy új, vékony kváderfalakkal övezett helyiséget építettek, aminek a révén a kolostor északi szárnya a nyugati szárny nyugati homlokzatáig tolódott előre. Az új helyiség északi kváderfalának néhány részletét és nyugati falalapozásának egy rövid fennmaradt szakaszát találtuk meg. Eme vékony kváderfal egy olyan alapozásra épült, amely a kolostor újonnan kialakított északnyugati sarkától kissé nyugat felé megtört vonalban folytatódott északnyugati irányba. A falrendszer délkeleti sarkát a későbbi provizori palota nyugati fala mellett találtuk meg (5., 27. képek). Az itt feltárt falsarok iránya illeszkedett a tőle keletre álló korai palotaépület tájolásához, tehát építése idején a korai palotaépület még minden bizonnyal állhatott. A régi palotaépület és az új falsarok között egy rámpát alakítottak ki, amely a falakkal övezett északi terület magasabban fekvő belső udvarára vezetett fel. A falsarok alapozása melletti rámpa feltöltési rétegéből 12.

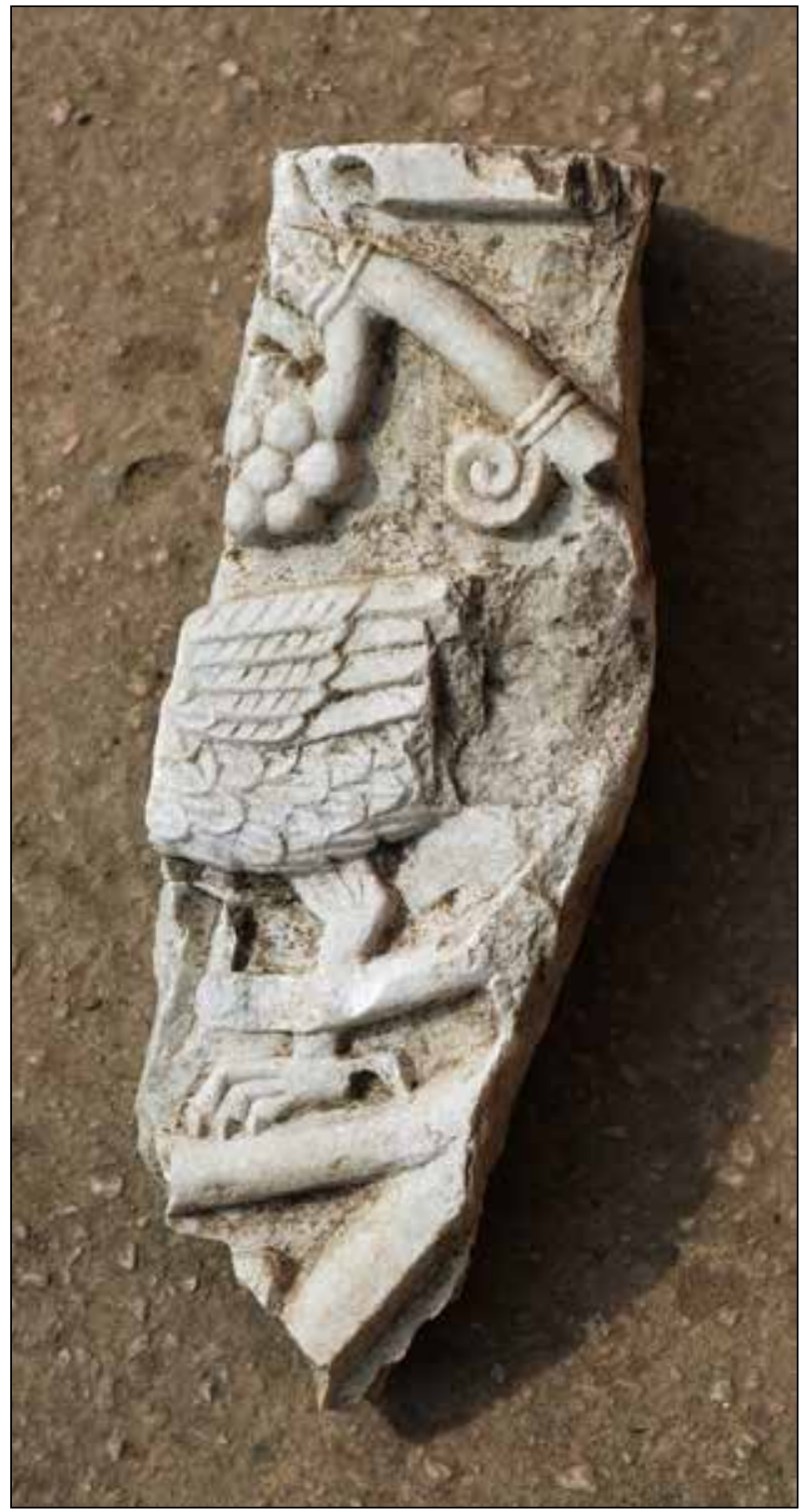

30. kép. Ívháromszöget díszítő román kori fehérmárvány faragvány szőlooiinda és madár ábrázolásával a káptalani épületet övező északi árok 13. századi betöltéséből, a 2017/7. szelvényből

Fig. 30. Romanesque white marble carving of a vine tendril and a bird, once decorating a spandrel, from the 13th-century fill of the northern ditch around the chapter building recovered from Trench 2017/7

század végi, 13. század eleji kerámiatöredékek kerültek elo, ${ }^{92}$ a falban pedig egy másodlagosan felhasznált 12. századi oszloplábazatot találtunk befalazva (28. kép). A falrendszer nyugati falának kiszedett alapárkát és kváderköveinek törmelékét még Kozák Károly figyelte meg a múzeum egykori képtárépülete és a gótikus püspöki palota 


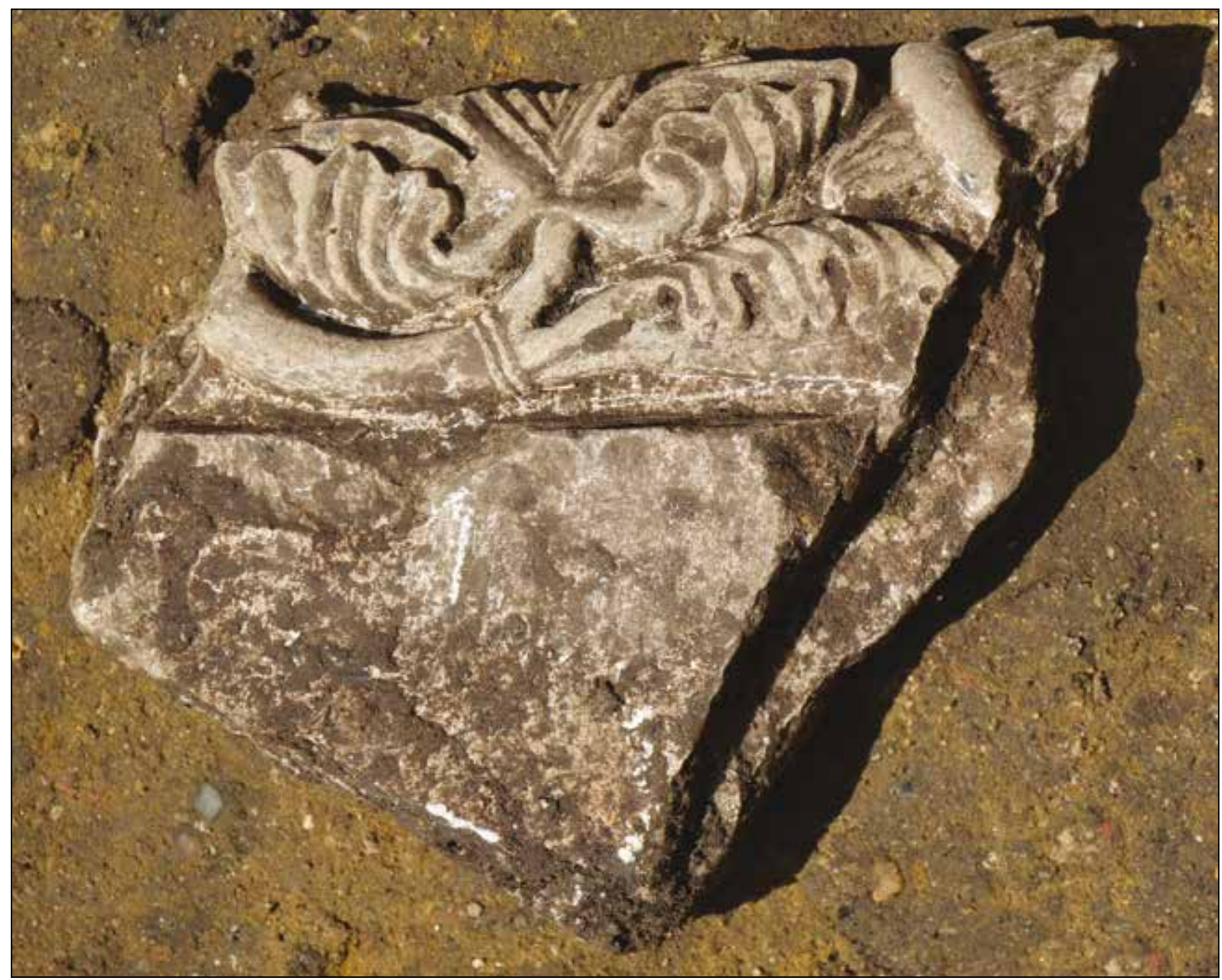

31. kép. Fehérmárványból készült indadíszes román kori párkány a káptalani épületet övező északi árok 13. századi betöltéséből, a 2017/7. szelvényből

Fig. 31. Tendril-ornamented Romanesque moulding of white marble from the 13th-century fill of the northern ditch around the chapter building recovered from Trench $2017 / 7$

közötti területen. Itt a falon kívül egy árok nyomai is előkerültek. A falakkal övezett területen belül épületek is állhattak. A déli fal mentén, a múzeum mai igazgatósági épületének kapuja előtt vízvezeték-építés során Kozák Károly ${ }^{93}$ és Nagy László ${ }^{4}$ is jelentős kőfal-maradványokra bukkant, a terület középső részén pedig szintén Nagy László, majd mi is kisebb kváderfal szakaszokat tártunk fel. Ezek a csak igen töredékesen ismert falmaradványok egy nagy méretü, jelentôs palotaépület létére vallanak, de ennek teljes kiterjedését és alaprajzát csak további ásatásokkal lehetne tisztázni (29. kép). E palota talán annak a korai, 11. századi palotaépületnek a funkcióját vehette át, amely a székesegyház délnyugati sarka előtt állt, és amit a 13. század elején

93 KoZÁK 1987.

94 NAGY L. 2015, 70-73. lebontottak. A 11. századi palotaépület helyén ugyanis a nyugati falrendszer építésénél valamivel később, egy íves sarkú, L alaprajzú falat építettek az emeletes kápolna és a nyugati falrendszer délkeleti sarka között. Az új falszakasz azonban nem épült közvetlenül hozzá a régebbi falsarokhoz: a kettő között fennmaradt a vár belsejébe vezető rámpa. E falnak a teljes keleti szakaszát feltártuk, nyugati végének pedig egyetlen kősorát találtuk meg a később ráépült provizori palota délnyugati sarka alatt (5. kép). A fal keleti szárán egy ajtót alakítottak ki, amely a székesegyház nyugati homlokzata előtti térre nyílott. A székesegyháztól nyugatra feltárt kőpor és kősifra rétegek a székesegyház nyugati részének 12. század második felére keltezhető építkezéseihez köthetők, az íves sarkú L alakú falat pedig ebbe a kőpor rétegbe alapozták. E fallal egy időben készült a térnek az a kőburkolatos szintje is, amelyre a fal 
ajtaja nyílott, és amely a román kori székesegyház szintjéhez igazodott.

A 13. század első felében a román kori püspöki palotát is átépíthették. A palota nyugati homlokzata előtt valamilyen faépítménynek, esetleg építési állványzatnak a cölöplyuk-sorát tártuk fel. Ennek keltezését a cölöplyukakból előkerült 13. századi kerámiatöredékek teszik lehetővé. A legészakabbi cölöplyuk a 12. századi püspöki palota északnyugati sarka előtt került eló (4. kép), ennek közelében a cölöplyukhoz tartozó szinten egy friesachi dénárt találtunk.

A vár délnyugti sarkában, a török kori ágyúdomb helyén 2019-ben egy K-Ny-i irányú falkiszedés árkát találtuk meg a benne lévő habarcscsal és alsó kőréteggel együtt. A falalapozás $110 \mathrm{~cm}$ széles volt, az alapárok szélessége alul $120 \mathrm{~cm}$, felül $160 \mathrm{~cm}$. A falkiszedést 13. századi kerámiával keltezett bontási törmelékréteg töltötte ki. A fal déli oldalán megtaláltuk a habarcsos építési szintjét és a hamus pusztulási rétegét, északi oldalán viszont az altalajig csak a bontási törmelékréteget találtuk. A falat összesen $670 \mathrm{~cm}$ hosszan tudtuk követni. A vastag fal, melyhez nem kapcsolódott padló, feltehetóen egy korai várfal lehetett, iránya a Hyppolit-kapu felé mutat. Pusztulása talán a tatárjárással állt összefüggésben.

A 13. század első felére kiépült egri püspöki központot a feltárt falmaradványok alapján kö- vetkezőképpen rekonstruálhatjuk: Az északról és nyugatról meredek, délról valamivel menedékesebb lejtővel határolt dombot körben kőfalak övezték. A falrendszer északkeleti részét a székesegyház északi oldalához csatlakozó káptalani kolostor, északnyugati sarkát pedig egy közel négyzetes alaprajzú belsővár képezte. E belső vár falrendszere a délkeleti sarokban nem futott neki a székesegyháznak, hanem előtte egy kis, kövezett burkolatú, négyzetes teret hagyott szabadon, amit északról a püspöki kápolna, északkeletről pedig a székesegyház és a káptalani kerengő előcsarnoka határolt, ezáltal a székesegyház nyugati kapuja, és a káptalani kolostor nem a belső-, hanem a külsővárból volt megközelíthető. A belső várból nyílott viszont a káptalani kolostor nyugati szárnyát elfoglaló püspöki palota, illetve annak déli végéhez csatlakozó emeletes püspöki kápolna, továbbá az udvar déli oldalának nyugati felén emelkedő palotaépület. Elképzelhetó, hogy ez az épület szolgálhatott Imre király egri szállásaként az uralkodó halála idején, 1204-ben. A palotákat övező belső várfal bejárata a déli oldal közepén nyílott, de egy ajtó kivezetett a székesegyház nyugati kapuja előtti terecskére is. A külső várfal a belsővár és a székesegyház déli oldala előtti területet vette körül, de pontos kiterjedését, és fóleg keleti lezárását ma még nem ismerjük (29. kép).

\section{IRODALOM}

2017b Koraközépkori udvarház Abasáron. In: H. Szilasi Á. (szerk.): Örökségünk védelme és jövője 2. A Dobó István Vármúzeumban 2016. február 4-5-én megrendezett tudományos konferencia tanulmánykötete. Studia Agriensia 33, Eger, 10-19.

2019a Jelentés az egri vár 2016-2017-ben lezajlott régészeti kutatásairól. In: H. Szilasi Á. (szerk.): Örökségünk védelme és jövője 3. A Dobó István Vármúzeumban 2017. február 9-10-én megrendezett restaurátor szimpózium tanulmánykötete. Studia Agriensia 38, Eger, 51-73.

2019b Az egri vár zászlódombjának feltárása. Várak, kastélyok, templomok - Évkönyv, 52-56.
} 
BuZÁs Gergely-KovÁcs Olivér

2019 Az Árpád-házi uralkodók sírjai. Budapest.

Casanelli, Roberto-Piva, Paolo

2010 Casanelli, R.-Piva, P. (eds): Lombardia Romanica. Milano.

DÉTSY MiHÁLY

1964 Az egri várszékesegyház építéstörténetének okleveles adatai. Múvészettörténeti Értesítő (Budapest) 13, 1-19.

DÉTSHY MiHÁLY-KoZÁK KÁROLY

1964 Az egri várban álló gótikus palota helyreállítása. Magyar Múemlékvédelem (Budapest) 2, 31-72.

1967 Az egri vár feltárása IV. Agria - Az Egri Múzeum Évkönyve (Eger) 5, 87-116.

1972 Eger vára. In: Voit P. et al. (szerk.): Magyarország Múemléki topográfiája 8, Heves Megye Múemlékei II. Budapest, 77-159.

GEREVICH TIBOR

1938 Magyarország románkori emlékei. Budapest.

GEREVICH LÁSZLó

1983 The Royal Court (curia), Provost's Residence and the Village at Dömös. Acta Archaeologica Academiae Scientiarum Hungariae (Budapest) 35, 385-409.

GYÖRFFY GYÖRGY

1984 Magyarország története a honfoglalástól a tatárjárásig. In: Bartha A. (szerk.): Magyarország története I.

Előzmények és magyar történet 1242-ig. I/1. Budapest, 575-1006.

1987 Az Árpád-kori Magyarország történeti földrajza III. Budapest.

HAVASI KRISZTINA

2003 „1200 körüli” faragványcsoport töredékei a középkori egri székesegyházból. Agria - Az Egri Múzeum Évkönyve (Eger) 39, 113-188.

2017 "Cuius corpus requiescit in ecclesia agriensi..." („Cuius corpus requiescit in ecclesia agriensi...").

Archaeologiai Értesítő (Budapest) 142, 129-166.

HómAN BÁLINT

1921 Magyar Történet I. Budapest.

1938 Szent István. Budapest.

IPOLYI ARNOLD

1865 Az egri megye Sz. János apostol és evangelistáról nevezett régi székesegyháza az egri várban. In:

Emlékkönyv Kis-Apponyi Bartakovics Béla érsek Aranymiséjének ünnepére. Eger, 95-171.

KANDRA KABOS

1883 A somboly-pankotai főesperestség. Századok (Budapest) 17, 582-592.

Karczag ÁkOs-SZabó TibOR

2012 Erdély, Partium és a Bánság erődített helyei. Budapest.

KÁRPÁTI JÁNOS

2010 Az egri püspökvár. Eger.

Kiss ATtila

2007 Úzok a Képes Krónikában. A nyugati oguz (úz) törzsek és a Magyar Királyság a XI. században.

Hadtörténelmi Közlemények (Budapest) 120, 549-576.

KosZTA LÁSZLó

2013 A kalocsai érseki tartomány kialakulása. Pécs.

2014 A bihari püspökség alapítása. In: Zsoldos A. (szerk.): Nagyvárad és Bihar a korai középkorban.

Tanulmányok Biharország történetéról 1. Nagyvárad, 41-81.

KOZÁK KÁROLY

1966 Az egri vár feltárása (1957-65) III. Agria - Az Egri Múzeum Évkönyve (Eger) 4, 97-152.

1969a Az egri vár feltárása (1957-67) V. Agria - Az Egri Múzeum Évkönyve (Eger) 6, 115-169.

1969b Az egri vár feltárása (1957-1968) VI. Agria - Az Egri Múzeum Évkönyve (Eger) 7, 179-208.

1972 Az egri várszékesegyház feltárása I. Agria - Az Egri Múzeum Évkönyve (Eger) 10, 159-190.

1974 Az egri várszékesegyház feltárása II. Agria - Az Egri Múzeum Évkönyve (Eger) 11-12, 131-158.

1975 Az egri várszékesegyház feltárása III. Agria - Az Egri Múzeum Évkönyve (Eger) 13, 81-99.

1979 Az egri vár Árpád-kori temetőjének feltárása I. Agria - Az Egri Múzeum Évkönyve (Eger) 16-17, 157-181.

1981 Az egri vár Árpád-kori temetőjének feltárása II. Agria - Az Egri Múzeum Évkönyve (Eger) 18, 5-46.

1983 Árpád-kori falu maradványainak feltárása az egri várban I. Agria - Az Egri Múzeum Évkönyve (Eger) 19, 75-110.

1984a Közép-Európa centrális templomai (IX-XI. század) (Die Zentralkirchen in Westeuropa [IX-XI. Jahrhundert]). A Veszprém Megyei Múzeumok Közleményei (Veszprém) 17, 107-144.

1984b Árpád-kori múhelyek és egy középkori fútőkemence az egri várban. In: Gömöri J. (szerk.): Iparrégészet. II. Iparrégészeti és archeológiai kutatások Magyarországon. Veszprém, 205-215. 
1986 Az egri vár Árpád-kori temetőjének feltárása III. Agria - Az Egri Múzeum Évkönyve (Eger) 22, 5-34.

1987 Leletmentés az egri várban I. (1985-86). Agria - Az Egri Múzeum Évkönyve (Eger) 23, 413-429.

1990 Az egri vár feltárása VII. (1957-1988). Agria - Az Egri Múzeum Évkönyve (Eger) 25-26, 317-375.

KozÁK KÁroly-SEDLmaYr JÁNOS

1972 Az egri vár Tömlöc- és Földbástyájának helyreállítása. Magyar Múemlékvédelem (Budapest) 1969-1970, 245-267.

1987 Az egri vár középkori kőtára. Eger.

KRISTÓ GYULA

1974 A XI. századi hercegség története Magyarországon. Budapest.

LÉNÁRT ANDOR

1982 Az egri vár feltárásának története 1949-ig. Studia Agriensis 2. Eger.

MORDOVIN MAXIM

2016 Várszervezet kialakulása a középkori Magyarországon, Csehországban és Lengyelországban a 10-12. században. Studia ad Archaeologiam Pazmaniensia 5. Budapest.

MRT 4 Torma, I. (szerk.): Magyarország Régészeti topográfiája 4. A pápai és a zirci járás. Budapest.

NAgy GÉZA BALÁzs

20041580 előtti adatok az egri püspöki vár történetéhez. Agria - Az Egri Múzeum Évkönyve (Eger) 40, 163-188.

NAGy LÁSZló

2015 Beszámoló az egri várban 2014-ben végzett régészeti munkákról. Castrum (Budapest) 18, 59-104.

PAULER GYULA

1899 Magyar nemzet története az Árpád-házi királyok alatt. Budapest.

RUPP JАКАВ

1868 Buda-Pest és környékének helyrajzi története. Pest.

SRH Scriptores Rerum Hungaricarum tempore ducum regumque stirpis Arpadianae gestarum. I-II. Edendo STEVENS, ULRICH operi praefuit Emericus Szentpétery. Budapest, 1937-1938. (reprint 1999).

2003 Burgkapellen. Andachts, Reprasentation und Wehrhaftigkeit im Mittelalter. Darmstadt.

SUGÁR ISTVÁN

1984 Az egri püspökök története. Budapest.

SZENTPÉTERY IMRE

1943 Az Árpád-házi királyok okleveleinek kritikai jegyzéke (Regesta regum stirpis Arpadianae critico diplomatica). II. kötet, 1. Füzet, 1255-1272. Budapest.

SZÉKELY GYÖRGY

1972 A székesfehérvári latinok és a vallonok a középkori Magyarországon. In: Kralovánszky A. (szerk.): Székesfehérvár évszázadai 2. - Középkor. Székesfehérvár, 45-72.

TAKÁCS IMRE

2001 Garamszentbenedek temploma és liturgikus felszerelése. In: Takács I. (szerk.): Paradisum plantavit. Bencés monostorok a középkori Magyarországon. Pannonhalma, 159-186.

TÓTH SÁNDOR

1994 A 11. századi magyarországi kőornamentika időrendjéhez. In: Mikó Á.-Takács I. (szerk.): Pannonia Regia. Múvészet a Dunántúlon 1000-1541. Kiállítási katalógus. Budapest, 54-62.

1998 Pillér és ív a magyar romanikában. In: Bardoly I.-László Cs. (szerk.): Koppány Tibor Hetvenedik Születésnapjára. Múvészettörténet - múemlékvédelem (Budapest) 10, 49-73.

TÓTH PÉTER

2007 A vallonok legkorábbi betelepülése Magyarországra. A Herman Ottó Múzeum Évkönyve (Miskolc) 46, 543-548.

TRAEGER, JÖRG

1980 Mittelalterliche Architekturfiktion. Die Allerheiligenkapelle am Regensburger Domkreutzgang.

München-Zürich.

WINTERFELD, DETHARD VON

1993 Die Kaiserdome Speyer, Mainz, Worms und ihr romanisches Umland. Würzburg.

WolF, ARNOLD

1971 S. Johannis in Curia. Die erzbischöfliche Pfalzkapelle auf der Südseite des Kölner Domes und ihre Nachfolgenbauten. Kölner Domblatt (Köln) 33/34, 125-174. 


\section{EMERGENCE OF THE ÁRPÁDIAN AGE EPISCOPAL CENTRE IN EGER}

\section{GERGELY BUZÁS}

The excavations between 2016 and 2019 in Eger Castle represent the most recent campaign in the investigation of its buildings begun in 1862 . We gained important new insights into the 11th-13th century history of the castle and the episcopal centre of Eger, principally from the observations made during the investigation of the area on the northern and western side of the medieval cathedral and on the castle's the south-western cannon emplacement mound. The overview of the architectural history of the episcopal centre before the Mongolian invasion of 1241 presented here is based on the assessment of the recent campaigns and of the excavations conducted by Károly Kozák between 1957 and 1989.

The earliest architectural complex on the castle hill was a manor house made up of a rotunda, a palace and a tower-like structure dating from the first half of the 11th century that were established over an existing cemetery. There is nothing to indicate that Eger had been an episcopal centre at this time; the buildings rather suggest a royal estate centre, which nevertheless had probably played an important role in the conversion of the broader area to Christianity. Although the diocese tradition recorded in the late 13th century linked the foundation of the Eger bishopric to King St. Stephen, the first bishop of Eger mentioned in the written sources, a certain Liduinus of Liège, was active in the second half of the 11th century: in a Namur chronicle written after 1064, he is mentioned as the bishop of Bihar, while the Liège necrologium designates him as bishop of Eger. It seems likely that the Bihar and Eger bishopric designated the same diocese, which had perhaps been created as a missionary diocese in St. Stephen's life and that its first permanent seat, established at an unknown date, was in the centre of the Bihar principality. Still during Liduinus' lifetime, probably after the Uz attack on Bihar in 1068, the episcopal seat was transferred from Bihar to Eger, first temporarily and then permanently towards the end of St. Ladislaus' reign, in the wake of the Cumanian attack of 1091 on Bihar.
In the second half of the 11th century, the tower-like building of the manor house was transformed into a two-storey chapel with four piers, probably in relation to the creation of the episcopal residence. At the turn of the 11th-12th centuries, when the seat of the bishopric was permanently established in Eger, various wooden structures, among them a wooden bell tower, were erected next to the two-storey chapel, and the construction of the three-nave cathedral in the Romanesque style - beginning with the chevet - was begun on the northern side of the early rotunda. In the 1130-1140s, in the time of Bishop Martyrius, the episcopal palace and the chapter buildings were constructed on the northern side of the cathedral, and the walls of the nave a chapel adjoining the early rotunda. In the second half of the 12th century, a cloister was built between the episcopal palace, the chapter building and the cathedral, which in the east adjoined a wing, and a chapel dedicated to St. Stephen was erected in the centre of the courtyard. A church dedicated to St. Peter was constructed east of the cathedral complex in the same period. The nave of the cathedral was completed in the early Gothic style under Bishop Katapán around 1200. In 1204, the bishop had King Emerich, who had died in Eger, buried in a vaulted grave chamber constructed in the nave. The quadrangular inner castle enclosed within a stone wall in front of the cathedral complex was probably built at the same time. Later, in the first half of the 13th century, the 11th century palace building was demolished and a wall was built in its place. A new palace was erected farther to the west; however, few wall remains of this new building are currently known. An outer castle ringed by stone walls was built on the southern side of the cathedral and the inner castle, of which a wall section whose foundation had been removed was uncovered under the castle's later south-western cannon emplacement mound.

A cikk a Creative Commons Attribution 4.0 International License (https://creativecommons.org/licenses/by/4.0) feltételei szerint publikált Open Access közlemény, melynek szellemében a cikk bármilyen médiumban szabadon felhasználható, megosztható és újraközölhető, feltéve, hogy az eredeti szerző és a közlés helye, illetve a CC License linkje és az esetlegesen végrehajtott módosítások feltüntetésre kerülnek. (SID_1) 